Supporting Information for

\title{
Rigidifying Cation-Tunable Nickel Catalysts Increases Activity and Polar Monomer Incorporation in Ethylene and Methyl Acrylate Copolymerization
}

\author{
Babak Tahmouresilerd, Dawei Xiao, and Loi H. Do* \\ Department of Chemistry, University of Houston, Houston, Texas, 77004 \\ Email: loido@uh.edu
}

TABLE OF CONTENTS

Experimental

$\underline{\text { Page(s) }}$

General Procedures

S4

Synthesis and Characterization $\quad$ S5-S9

Scheme S1 Synthesis of Complex Ni2 S5

$\begin{array}{lll}\text { Scheme S2 Synthesis of Complex Ni3 } & \text { S7 }\end{array}$

Metal Binding Studies

Method Continuous Variation $\quad$ S10

Figure S1 Job-Plot of Ni3 $+\mathrm{NaBAr}_{4}{ }_{4} \quad \mathrm{~S} 11$

Table S1 Data and Calculations for Job Plot of Ni3 $+\operatorname{NaBAr}_{4} \quad$ S12

$\begin{array}{lll}\text { Figure S2 Job-Plot of Ni3 }+\mathrm{LiBAr}_{4} & \mathrm{~S} 13\end{array}$

Table S2 Data and Calculations for Job Plot of Ni3 $+\operatorname{LiBAr}_{4} \quad$ S14

Metal Titration and Fitting $\quad$ S15-S17

$\begin{array}{lll}\text { Figure S3 } & \text { Titration of Ni3 }+\mathrm{NaBAr}^{\mathrm{F}} \text { by NMR } & \mathrm{S} 18\end{array}$

$\begin{array}{lll}\text { Table S3 NMR Titration Data for Ni3 }+\mathrm{NaBAr}^{\mathrm{F}} & \mathrm{S} 18\end{array}$

$\begin{array}{lll}\text { Figure S4 } & \text { Titration of Ni3 }+\operatorname{LiBAr}_{4} \text { by NMR } & \text { S19 }\end{array}$

$\begin{array}{lll}\text { Table S4 NMR Titration Data for Ni3 }+\mathrm{LiBAr}_{4} & \mathrm{~S} 19\end{array}$

$\begin{array}{lll}\text { Figure S5 } & \text { Bindfit Global Analysis of Ni3 }+\mathrm{LiBAr}_{4} & \text { S20 }\end{array}$

Figure S6 Bindfit Global Analysis of Ni3 $+\mathrm{NaBAr}_{4}{ }_{4} \quad$ S20

$\begin{array}{lll}\text { Table S5 Summary of Binding Constants Calculated } & \text { S21 }\end{array}$

\section{Characterization Data}

Figure S7

Figure S8

Figure S9

Figure S10

Figure S1 1

Figure S12

Figure S13

Figure S14

Figure S15

Figure S16

Figure S17

Figure S18

Figure S19

Figure S20
${ }^{1} \mathrm{H}$ NMR Spectrum of 2a

${ }^{31} \mathrm{P}$ NMR Spectrum of 2a

${ }^{1} \mathrm{H}$ NMR Spectrum of $\mathbf{3 a}$

${ }^{31} \mathrm{P}$ NMR Spectrum of $\mathbf{3 a}$

${ }^{1} \mathrm{H}$ NMR Spectrum of $\mathbf{4 a}$

${ }^{31} \mathrm{P}$ NMR Spectrum of $\mathbf{4 a}$

${ }^{1} \mathrm{H}$ NMR Spectrum of $\mathbf{6 a}$

${ }^{13} \mathrm{C}$ NMR Spectrum of $\mathbf{6 a}$

${ }^{31} \mathrm{P}$ NMR Spectrum of $\mathbf{6 a}$

${ }^{1} \mathrm{H}$ NMR Spectrum of Ni2

${ }^{13} \mathrm{C}$ NMR Spectrum of Ni2

${ }^{31} \mathrm{P}$ NMR Spectrum of Ni2

${ }^{1} \mathrm{H}-{ }^{13} \mathrm{C}$ Correlation (HMQC) Spectrum of $\mathbf{N i 2}$

${ }^{19} \mathrm{~F}$ NMR Spectrum of Ni2
S22

S23

S24

S25

S26

S27

S28

S29

S30

S31

S32

S33

S34

S35 
$\begin{array}{lll}\text { Figure S21 } & { }^{1} \mathrm{H} \text { NMR Spectrum of } \mathbf{2 b} & \text { S36 }\end{array}$

$\begin{array}{lll}\text { Figure S22 } & { }^{13} \mathrm{C} \text { NMR Spectrum of } \mathbf{2 b} & \text { S37 }\end{array}$

$\begin{array}{lll}\text { Figure S23 } & \text { 31P NMR Spectrum of } \mathbf{2 b} & \text { S38 }\end{array}$

$\begin{array}{lll}\text { Figure S24 } & { }^{1} \mathrm{H} \text { NMR Spectrum of } \mathbf{3 b} & \text { S39 }\end{array}$

$\begin{array}{lll}\text { Figure S25 } & { }^{13} \mathrm{C} \text { NMR Spectrum of } \mathbf{3 b} & \text { S40 }\end{array}$

$\begin{array}{lll}\text { Figure S26 } & \text { 31P NMR Spectrum of 3b } & \text { S41 }\end{array}$

$\begin{array}{lll}\text { Figure S27 } & { }^{1} \mathrm{H} \text { NMR Spectrum of } \mathbf{4 b} & \text { S42 }\end{array}$

$\begin{array}{lll}\text { Figure S28 } & { }^{13} \mathrm{C} \text { NMR Spectrum of } \mathbf{4 b} & \text { S43 }\end{array}$

$\begin{array}{lll}\text { Figure S29 } & \text { 31P NMR Spectrum of } \mathbf{4 b} & \text { S44 }\end{array}$

$\begin{array}{lll}\text { Figure S30 } & { }^{1} \mathrm{H} \text { NMR Spectrum of } \mathbf{6 b} & \text { S45 }\end{array}$

$\begin{array}{lll}\text { Figure S31 } & { }^{13} \mathrm{C} \text { NMR Spectrum of } \mathbf{6 b} & \text { S46 }\end{array}$

Figure S32 $\quad{ }^{1} \mathrm{H}-{ }^{13} \mathrm{C}$ Correlation (HMQC) Spectrum of $\mathbf{6 b} \quad$ S47

$\begin{array}{lll}\text { Figure S33 } & { }^{31} \mathrm{P} \text { NMR Spectrum of } \mathbf{6 b} & \text { S48 }\end{array}$

$\begin{array}{lll}\text { Figure S34 } & { }^{1} \mathrm{H} \text { NMR Spectrum of Ni3 } & \text { S49 }\end{array}$

$\begin{array}{lll}\text { Figure S35 } & { }^{13} \mathrm{C} \text { NMR Spectrum of Ni3 } & \text { S50 }\end{array}$

$\begin{array}{lll}\text { Figure S36 } & { }^{31} \mathrm{P} \text { NMR Spectrum of Ni3 } & \text { S51 }\end{array}$

$\begin{array}{lll}\text { Figure S37 } & { }^{19} \mathrm{~F} \text { NMR Spectrum of Ni3 } & \text { S52 }\end{array}$

Figure S38 $\quad{ }^{1} \mathrm{H}-{ }^{13} \mathrm{C}$ Correlation (HMQC) Spectrum of Ni3 $\quad$ S53

Figure S39 $\quad{ }^{1} \mathrm{H}-{ }^{1} \mathrm{H}$ Correlation (COSY) Spectrum of Ni3 $\quad$ S54

Figure S40 High-resolution Mass Spectrum of 6a $\quad$ S55

Figure S41 High-resolution Mass Spectrum of $6 \mathbf{b} \quad$ S55

Figure S42 Cyclic Voltammograms of Ni1, Ni2, and Ni3 S56

Polymerization Studies

General Polymerization Procedures $\quad$ S57

$\begin{array}{lll}\text { Table S6 Time Study of Ethylene Homopolymerization } & \text { S58 }\end{array}$

$\begin{array}{lll}\text { Table S7 } & \text { Ethylene Polymerization without Borane Cocatalyst } & \text { S58 }\end{array}$

Table S8 $\quad$ Ethylene Polymerization with Different Sodium Salts $\quad$ S58

Table S9 Comparison of Nickel Catalysts with Similar Systems $\quad$ S59

MA Incorporation Calculations $\quad$ S60

Figure S43 $\quad{ }^{1} \mathrm{H}$ NMR Spectrum of PE from Ni3 $\quad$ S61

Figure S44-S45 ${ }^{13} \mathrm{C}$ NMR Spectrum of PE from Ni2 S62-63

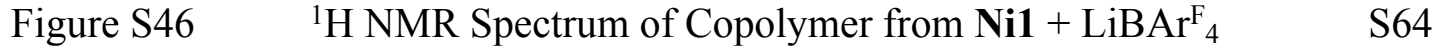

Figure S47 $\quad{ }^{1} \mathrm{H}$ NMR Spectrum of Copolymer from Ni3 $+\operatorname{LiBAr}^{\mathrm{F}}{ }_{4} \quad \mathrm{~S} 65$

Figure S48 $\quad{ }^{1} \mathrm{H}$ NMR Spectrum of Copolymer from Ni3 $+\mathrm{NaBAr}^{\mathrm{F}}{ }_{4} \quad \mathrm{~S} 66$

Figure S49-S50 ${ }^{13} \mathrm{C}$ NMR Spectrum of Copolymer from Ni3 $+\mathrm{NaBAr}^{\mathrm{F}}{ }_{4} \quad \mathrm{~S} 67-68$

$\begin{array}{lll}\text { Figure S51 } & { }^{1} \mathrm{H} \text { NMR Spectrum of PMA from Ni3 } & \text { S69 }\end{array}$

$\begin{array}{lll}\text { Figure S52 GPC Trace of PE from Ni3 } & \text { S70 }\end{array}$

$\begin{array}{lll}\text { Figure S53 GPC Trace of PE from Ni2 } & \text { S70 }\end{array}$

$\begin{array}{lll}\text { Figure S54 GPC Trace of Copolymer from Ni3 } & \text { S71 }\end{array}$

$\begin{array}{lll}\text { Figure S55 } & \text { GPC Trace of Copolymer from Ni3 } & \text { S71 }\end{array}$

Figure S56 GPC Trace of Copolymer from Ni3 $+\mathrm{LiBAr}_{4}{ }_{4} \quad \mathrm{~S} 72$

$\begin{array}{lll}\text { Figure S57 GPC Trace of Copolymer from Ni3 }+\mathrm{LiBAr}_{4} & \mathrm{~S} 72\end{array}$

$\begin{array}{lll}\text { Figure S58 } & \text { NMR Spectra of Ni3 }+\mathrm{B}\left(\mathrm{C}_{6} \mathrm{~F}_{5}\right)_{3} & \mathrm{~S} 73\end{array}$

\section{X-ray Crystallographic Studies}

Table S10 Representative Bond Lengths and Angles for Ni2 and Ni3 
$\begin{array}{lll}\text { Figure S59 } & \text { X-ray structure of Ni2 } & \text { S75 }\end{array}$

$\begin{array}{lll}\text { Figure S60 } & \text { X-ray structure of Ni3 } & \text { S76 }\end{array}$

$\begin{array}{llr}\text { Table S11 Crystal Data for Ni2 and Ni3 } & \text { S77 }\end{array}$

References

S78-S79 


\section{EXPERIMENTAL}

\section{GENERAL PROCEDURES}

Commercial reagents were used as received. All air- and water-sensitive manipulations were performed using standard Schlenk techniques or under a nitrogen atmosphere using a glovebox. Anhydrous solvents were obtained from an Innovative Technology solvent drying system saturated with argon. NMR spectra were acquired using JEOL spectrometers (ECA-400, 500, and 600) and referenced using residual solvent peaks. All ${ }^{13} \mathrm{C}$ NMR spectra were proton decoupled. ${ }^{31} \mathrm{P}$ NMR spectra were referenced to phosphoric acid. For polymer characterization, ${ }^{1} \mathrm{H}$ NMR spectroscopy: each NMR sample contained $\sim 20 \mathrm{mg}$ of polymer in $0.5 \mathrm{~mL}$ of 1,1,2,2-tetrachloroethane- $d_{2}$ (TCE$d_{2}$ ) and was recorded on a $500 \mathrm{MHz}$ spectrometer using standard acquisition parameters at 120 ${ }^{\circ} \mathrm{C} .{ }^{13} \mathrm{C}$ NMR spectroscopy: each NMR sample contained $\sim 50 \mathrm{mg}$ of polymer in $0.5 \mathrm{~mL}$ of TCE$d_{2}$ and was recorded at $120^{\circ} \mathrm{C}(125 \mathrm{MHz})$. The samples were acquired using a $90^{\circ}$ pulse of 11.7 $\mu \mathrm{s}$, a relaxation delay of $4 \mathrm{~s}$, an acquisition time of $0.81 \mathrm{~s}$, and inverse gated decoupling. The samples were preheated for $30 \mathrm{~min}$ prior to data acquisition. The carbon spectra were assigned based on the chemical shift values reported in the literature. The NMR spectra of poly(ethyleneco-MA) matched with those reported in the literature. ${ }^{1,2}$ High-resolution mass spectra were obtained from the mass spectral facility at the University of Texas at Austin. Elemental analyses were performed by Atlantic Microlab. Compound $\mathbf{1 b},{ }^{3}$ compound $5,{ }^{4}$ and Ni1 ${ }^{5}$ were synthesized according to literature procedures. 


\section{SYNTHESIS AND CHARACTERIZATION}

Ni2 was synthesized as described below:

A)<smiles>COc1ccccc1Br</smiles>

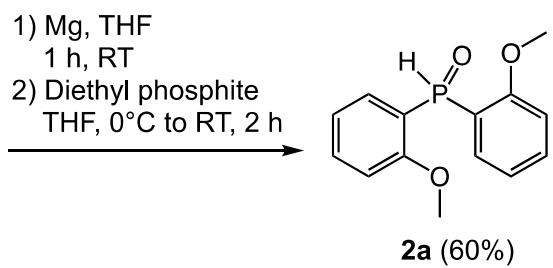<smiles>COc1ccccc1P(=O)(O)c1ccc(C(=O)O[Na])cc1OC</smiles><smiles>COc1ccc(P(=O)(Cl)c2ccccc2OC)cc1OC</smiles>

B)<smiles>COc1ccccc1P(c1ccccc1Br)c1ccccc1OC</smiles>

1) $\mathrm{nBuLi}$

$\mathrm{THF},-78^{\circ} \mathrm{C}, 20 \mathrm{~min}$

2) $4 a$

THF, warm to RT, $18 \mathrm{~h}$

5
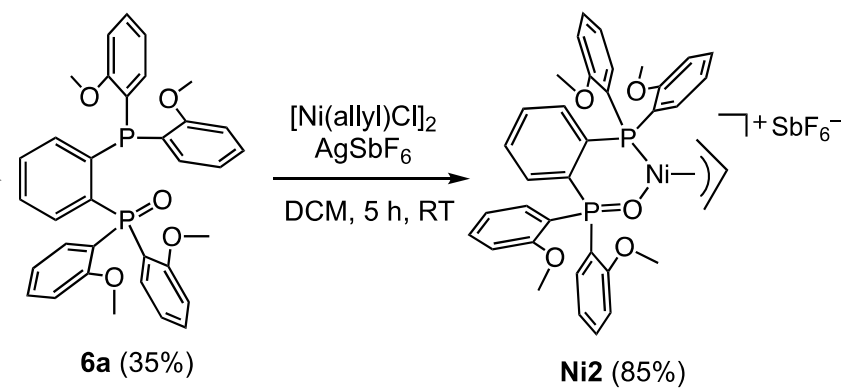

Scheme S1. Synthesis of complex Ni2.

\section{Synthesis of ligand and Ni2 complex}

\section{Preparation of bis(2-methoxyphenyl)phosphine oxide (2a)}<smiles>COc1ccccc1P(=O)(O)c1ccccc1OC</smiles>

Safety Note: This reaction is exothermic so safety precautions should be taken. Bis(2-methoxyphenyl)phosphine oxide was synthesized according to a literature procedure with some minor modifications. ${ }^{6}$ To a suspension of magnesium (50 mmol, $1.22 \mathrm{~g})$ in anhydrous THF $(20 \mathrm{~mL})$, 2-bromoanisole $(40 \mathrm{mmol}, 5 \mathrm{~mL})$ was added. The reaction mixture was stirred at RT until a significant amount of magnesium was consumed. The flask was then cooled to $4{ }^{\circ} \mathrm{C}$ using an ice bath and a solution of diethyl phosphite $(15.5 \mathrm{mmol}, 2 \mathrm{~mL})$ in anhydrous THF $(3 \mathrm{~mL})$ was added dropwise to the reaction mixture over $15 \mathrm{~min}$. The reaction mixture was stirred for an additional $30 \mathrm{~min}$ at $4{ }^{\circ} \mathrm{C}$ and $2 \mathrm{~h}$ at RT. After stirring, $\mathrm{HCl}(6.0 \mathrm{M})$ was added dropwise to the reaction mixture at low temperature and stirred for $30 \mathrm{~min}$. The resulting product was extracted into dichloromethane $(3 \times 15 \mathrm{~mL})$. The organic layers were dried over anhydrous sodium sulfate, filtered to remove the salt, and evaporated under reduced pressure. The solid was washed with hexane to afford $2 \mathrm{a}$ in $60 \%$ yield. ${ }^{1} \mathrm{H}$ NMR $\left(\mathrm{CDCl}_{3}, 500 \mathrm{MHz}\right): \delta(\mathrm{ppm}) 8.84-7.77\left(\mathrm{~d}, J_{\mathrm{PH}}=535 \mathrm{~Hz}, 1 \mathrm{H}\right), 7.59(\mathrm{~m}, 4 \mathrm{H}), 7.06\left(\mathrm{t}, J_{\mathrm{HH}}\right.$ $=5 \mathrm{~Hz}, 2 \mathrm{H}), 6.97\left(\mathrm{t}, J_{\mathrm{HH}}=10 \mathrm{~Hz}, 2 \mathrm{H}\right), 3.79(\mathrm{~s}, 6 \mathrm{H}) .{ }^{31} \mathrm{P} \mathrm{NMR}\left(\mathrm{CDCl}_{3}, 243 \mathrm{MHz}\right): \delta(\mathrm{ppm})$ 9.0. 


\section{Preparation of bis(2-methoxyphenyl)phosphinic acid (3a)}<smiles>COc1ccccc1P(=O)(O)c1ccccc1OC</smiles>

Bis(2-methoxyphenyl)phosphinic acid was synthesized according to a literature procedure with minor modifications. ${ }^{7}$ Aqueous hydrogen peroxide $(30 \%(\mathrm{w} / \mathrm{w})$, $8 \mathrm{~mL})$ was added to a solution containing $2 \mathrm{a}(3.82 \mathrm{mmol}, 1.0 \mathrm{~g})$ and sodium hydroxide $(5.0 \mathrm{~N}, 8 \mathrm{~mL})$ and then stirred under reflux condition for $1 \mathrm{~h}$. The reaction mixture was cooled down to $4{ }^{\circ} \mathrm{C}$ and concentrated hydrochloric acid was added dropwise to induce precipitation of the product. The resulting white solid was isolated by filtration, washed with water $(3 \times 20 \mathrm{~mL})$ and diethyl ether $(3 \times 10 \mathrm{~mL})$, and then dried under vacuum to give 3a in $78 \%$ yield. ${ }^{1} \mathrm{H}$ NMR (DMSO- $d_{6}, 400 \mathrm{MHz}$ ): $\delta(\mathrm{ppm}) 7.71-7.76(\mathrm{~m}, 2 \mathrm{H}$ ), $7.47\left(\mathrm{t}, J_{\mathrm{HH}}=10 \mathrm{~Hz}, 2 \mathrm{H}\right), 6.94-7.05(\mathrm{~m}, 4 \mathrm{H}), 3.51(\mathrm{~s}, 6 \mathrm{H}) .{ }^{31} \mathrm{P}$ NMR (DMSO- $\left.d_{6}, 243 \mathrm{MHz}\right): \delta$ (ppm) 20.1 .

\section{Preparation of bis(2-methoxyphenyl)phosphinic chloride (4a)}<smiles>COc1ccccc1P(=O)(O)c1ccccc1OC</smiles>

Bis(2-methoxyphenyl)phosphinic chloride was synthesized according to a literature procedure with modifications. ${ }^{7}$ A suspension of $\mathbf{3 a}(3.6 \mathrm{mmol}, 1.0 \mathrm{~g})$ and thionyl chloride $(20 \mathrm{~mL})$ in $30 \mathrm{~mL}$ of anhydrous toluene was heated to $80^{\circ} \mathrm{C}$ and stirred under nitrogen for $3 \mathrm{~h}$. The solvent was removed under vacuum and the remaining product was washed with anhydrous pentane to give an off-white solid in $80 \%$ yield. The solid was stored under an air- and moisture-free atmosphere to protect it from hydrolysis. ${ }^{1} \mathrm{H}$ NMR $\left(\mathrm{CDCl}_{3}, 400 \mathrm{MHz}\right): \delta(\mathrm{ppm}) 7.93-8.01\left(\mathrm{dd}, J_{\mathrm{HH}}\right.$ $=10 \mathrm{~Hz}, 2 \mathrm{H}), 7.48-7.56(\mathrm{~m}, 2 \mathrm{H}), 7.08-7.12(\mathrm{~m}, 2 \mathrm{H}), 6.86-6.91(\mathrm{~m}, 2 \mathrm{H}), 3.64(\mathrm{~s}, 6 \mathrm{H}) .{ }^{31} \mathrm{P}$ NMR $\left(\mathrm{CDCl}_{3}, 162 \mathrm{MHz}\right): \delta(\mathrm{ppm}) 38.0$.

\section{Preparation of ligand of 6 a}

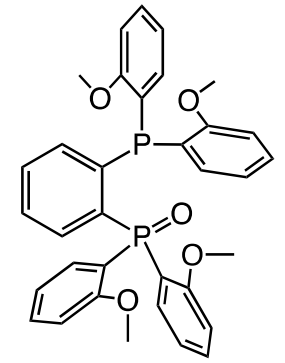

A $100 \mathrm{~mL}$ Schlenk flask was charged with $5(0.95 \mathrm{mmol}, 381 \mathrm{mg})$ and $20 \mathrm{~mL}$ of anhydrous THF. The flask was cooled down to $-78{ }^{\circ} \mathrm{C}$ and $n \mathrm{BuLi}(1.6 \mathrm{M}$ in hexane, $0.95 \mathrm{mmol}, 0.6 \mathrm{~mL}$ ) was added dropwise via a syringe. The resulting yellow solution was stirred for $20 \mathrm{~min}$. A solution of $4 \mathbf{a}(0.95 \mathrm{mmol}, 280 \mathrm{mg})$ in $10 \mathrm{~mL}$ of anhydrous THF was slowly added via a syringe and stirred for 30 min. The reaction mixture was warmed up to RT and stirred for another $18 \mathrm{~h}$. The resulting solution was quenched with $30 \mathrm{~mL}$ deionized water, extracted into dichloromethane $(3 \times 20 \mathrm{~mL})$, and the organic layer was dried over anhydrous sodium sulfate. The crude solid obtained after evaporation was purified by silica gel column chromatography $\left(\mathrm{EtOAc} / \mathrm{MeOH} / \mathrm{CH}_{3} \mathrm{Cl}, 10: 1: 1, \mathrm{v} / \mathrm{v}\right.$ ) to afford $\mathbf{6 a}$ as a white solid in $35 \%$ yield. ${ }^{1} \mathrm{H}$ NMR (CDCl, $400 \mathrm{MHz}): \delta(\mathrm{ppm}) 8.46(\mathrm{br}, 1 \mathrm{H}), 8.03-8.10(\mathrm{~m}, 1 \mathrm{H}), 7.53-7.59$ (q, $J_{\mathrm{HH}}=10 \mathrm{~Hz}$, $3 \mathrm{H}), 7.38\left(\mathrm{t}, J_{\mathrm{HH}}=10 \mathrm{~Hz}, 2 \mathrm{H}\right), 7.20\left(\mathrm{t}, J_{\mathrm{HH}}=10 \mathrm{~Hz}, 3 \mathrm{H}\right), 7.01(\mathrm{br}, 2 \mathrm{H}), 6.83(\mathrm{br}, 2 \mathrm{H}), 6.66\left(\mathrm{t}, J_{\mathrm{HH}}\right.$ $=10 \mathrm{~Hz}, 4 \mathrm{H}), 6.31(\mathrm{br}, 2 \mathrm{H}), 3.60(\mathrm{~s}, 9 \mathrm{H}), 3.49(\mathrm{~s}, 3 \mathrm{H}) .{ }^{13} \mathrm{C} \mathrm{NMR}\left(\mathrm{CDCl}_{3}, 125 \mathrm{MHz}\right): \delta(\mathrm{ppm})$ 207.00, 162.06, 160.80, 140.13, 139.19, 138.36, 138.10, 135.35, 135.22, 134.48, 133.93, 133.79, 133.09, 130.91, 129.58, 128.67, 128.58, 125.31, 121.84, 120.97, 120.57, 110.79, 109.84, 55.24, 31.01. ${ }^{31} \mathrm{P}$ NMR $\left(\mathrm{CDCl}_{3}, 162 \mathrm{MHz}\right): \delta(\mathrm{ppm}) 27.92$ and -30.73. ESI-MS(+) calc. for $\mathrm{C}_{34} \mathrm{H}_{32} \mathrm{O}_{5} \mathrm{P}_{2}$ $[\mathrm{M}+\mathrm{H}]^{+}=583.1800$, found 583.1789 . 


\section{Preparation of Complex Ni2}

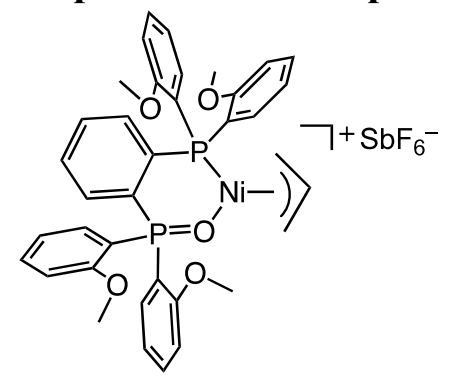

Inside the glovebox, ligand 6a $(0.17 \mathrm{mmol}, 100 \mathrm{mg})$, silver hexafluoroantimonate(V) $(0.17 \mathrm{mmol}, 59 \mathrm{mg})$, and $[\mathrm{Ni}(\text { allyl }) \mathrm{Cl}]_{2}(0.9$ mmol, $23.2 \mathrm{mg}$ ) were mixed in anhydrous dichloromethane and stirred at RT for $5 \mathrm{~h}$. The reaction mixture was filtered and the solvent was evaporated. The resulting solid was washed with pentane $(3 \times 10 \mathrm{~mL})$ and dried under vacuum. The crude compound was recrystallized in dichloromethane layered with pentane to obtain a yellow product in $85 \%$ yield. ${ }^{1} \mathrm{H}$ NMR $\left(\mathrm{CDCl}_{3}, 400 \mathrm{MHz}\right): \delta(\mathrm{ppm}) 7.51-7.62(\mathrm{~m}, 6 \mathrm{H})$, 7.34 (br, 1H), 7.18 (br, 3H), 6.99 (br, 6H), 6.85 (br, 2H), 6.61 (br, 2H), 5.40 (br, 1H), 3.82 (s, 6 $\mathrm{H}), 3.57$ (s, 6H), 2.04 (br, 2H), 1.66 (s, 2H). ${ }^{13} \mathrm{C} \mathrm{NMR}\left(\mathrm{CDCl}_{3}, 101 \mathrm{MHz}\right): 159.78,158.64,136.21$, 134.56, 132.42, 132.36, 132.27, 132.12, 131.86, 130.72, 128.54, 128.53, 128.39, 127.36, 126.55, $126.55,123.62,123.61,119.81,119.73,119.52,119.39,114.58,113.50,112.08,110.31,110.25$, 109.66, 54.13, 53.94. ${ }^{19} \mathrm{~F}$ NMR $\left(470 \mathrm{MHz} \mathrm{CDCl}_{3}\right) \delta-62.29$ (s), -100 (br), -130 (br). ${ }^{31} \mathrm{P} \mathrm{NMR}$ $\left(\mathrm{CDCl}_{3}, 202 \mathrm{MHz}\right): \delta$ (ppm) 44.37 and -2.67. Analytical Calculated for $\mathrm{C}_{37} \mathrm{H}_{37} \mathrm{~F}_{6} \mathrm{NiO}_{5} \mathrm{P}_{2} \mathrm{Sb}: \mathrm{C}$, 48.41; H, 4.06. Found C, 47.68; H, 4.12.

Ni3 was synthesized as described below:

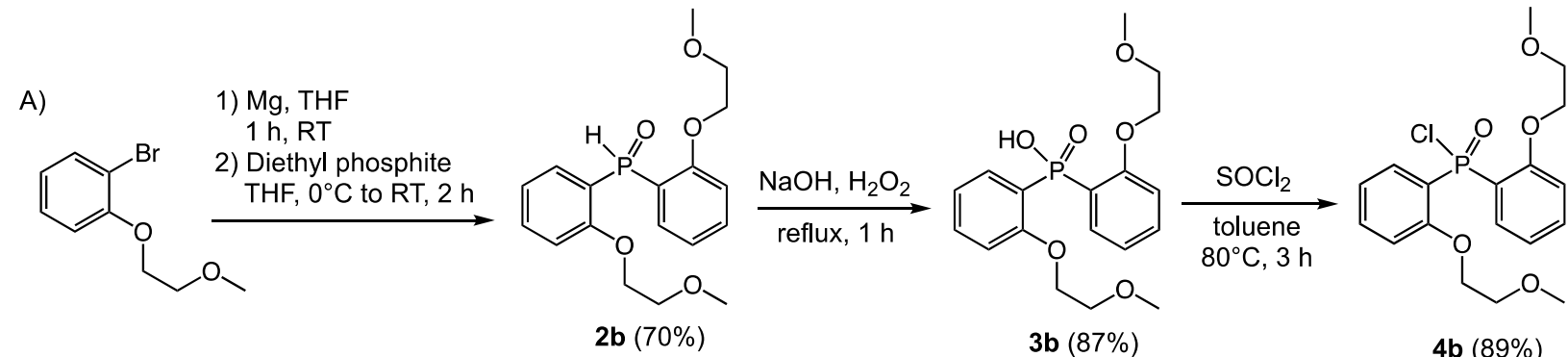

B)

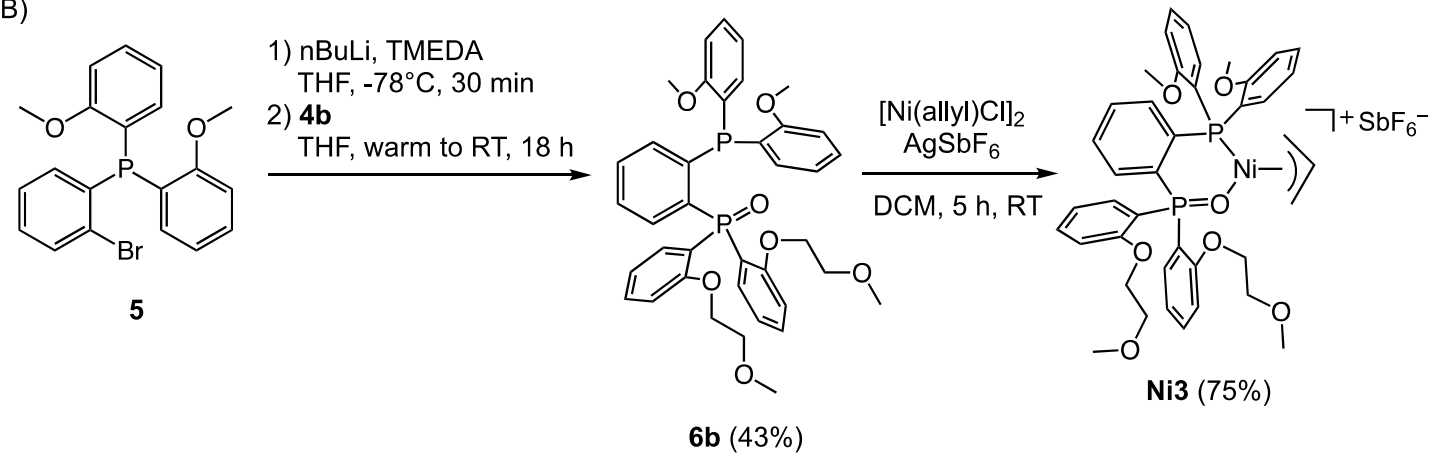

Scheme S2. Synthesis of complex Ni3. 


\section{Preparation of bis(2-(2-methoxyethoxy)phenyl)phosphine oxide (2b)}

Safety Note: This is an exothermic reaction so safety precautions should be
taken. Compound $\mathbf{1 b}(10.8 \mathrm{mmol}, 2.5 \mathrm{~g})$ was added to a suspension of
magnesium $(13.4 \mathrm{mmol}, 0.322 \mathrm{~g})$ in anhydrous THF $(20 \mathrm{~mL})$. The reaction
mixture was stirred at $\mathrm{RT}$ until a significant amount of magnesium was
$\begin{aligned} & \text { consumed. The reaction mixture was cooled down to } 4{ }^{\circ} \mathrm{C} \text { using an ice bath and } \\ & \text { a solution of diethyl phosphite }(4.2 \mathrm{mmol}, 574 \mathrm{mg}) \text { in anhydrous THF }(10 \mathrm{~mL}) \\ & \text { was added dropwise into the reaction mixture over } 15 \text { min and then stirred for } \\ & \text { additional } 30 \text { min at } 4{ }^{\circ} \mathrm{C} \text { and } 2 \mathrm{~h} \text { at RT. After the reaction was complete, }\end{aligned}$ aqueous $\mathrm{HCl}(6 \mathrm{M})$ was added dropwise to the reaction mixture at low temperature and stirred for $30 \mathrm{~min}$. The resulting solution was extracted with dichloromethane $(3 \times 15 \mathrm{~mL})$. The extracted organic layers were dried over anhydrous sodium sulfate, filtered to remove the salt, and evaporated under reduced pressure. The solid obtained was washed with hexane to afford $\mathbf{2} \mathbf{b}$ in $70 \%$ yield. ${ }^{1} \mathrm{H}$ NMR $\left(\mathrm{CDCl}_{3}, 400 \mathrm{MHz}\right): \delta(\mathrm{ppm}) 8.87-7.57\left(\mathrm{~d}, J_{\mathrm{PH}}=780 \mathrm{~Hz}, 1 \mathrm{H}\right), 7.69-7.75(\mathrm{q}$, $\left.J_{\mathrm{HH}}=10 \mathrm{~Hz}, 2 \mathrm{H}\right), 7.49-7.53(\mathrm{~m}, 2 \mathrm{H}), 7.09\left(\mathrm{t}, J_{\mathrm{HH}}=10 \mathrm{~Hz}, 2 \mathrm{H}\right), 6.90(\mathrm{t}, 2 \mathrm{H}), 4.04(\mathrm{~m}, 4 \mathrm{H}), 3.54$ (m, 4H), $3.33(\mathrm{~s}, 6 \mathrm{H}) .{ }^{13} \mathrm{C}$ NMR $\left(\mathrm{CDCl}_{3}, 125 \mathrm{MHz}\right): \delta(\mathrm{ppm})$ 160.9, 133.93, 133.64, 133.57, $120.93,120.74,119.90,111.84,111.79,70.59,67.89,59.19 .{ }^{31} \mathrm{P} \mathrm{NMR}\left(\mathrm{CDCl}_{3}, 162 \mathrm{MHz}\right): \delta(\mathrm{ppm})$ 8.78 .

\section{Preparation of bis(2-(2-methoxyethoxy)phenyl)phosphinic acid (3b)}

Hydrogen peroxide $\left(30 \%(\mathrm{w} / \mathrm{w})\right.$ in $\left.\mathrm{H}_{2} \mathrm{O}, 8 \mathrm{~mL}\right)$ was added to an aqueous solution
containing $2 \mathbf{b}(3.57 \mathrm{mmol}, 1.25 \mathrm{~g})$ and sodium hydroxide $(5.0 \mathrm{~N}, 8 \mathrm{~mL})$ and then
stirred under reflux condition for $1 \mathrm{~h}$. The reaction mixture was cooled down to
$4{ }^{\circ} \mathrm{C}$ and concentrated hydrochloric acid was added dropwise to precipitate out
the product. The resulting white solid was isolated by filtration, washed with
water $(3 \times 20 \mathrm{~mL})$ and diethyl ether $(3 \times 10 \mathrm{~mL})$, and then dried under vacuum to
give $3 \mathrm{~b}$ in $87 \%$ yield. ${ }^{1} \mathrm{H}$ NMR $\left(\mathrm{CDCl} l_{3}, 400 \mathrm{MHz}\right): \delta(\mathrm{ppm}) 7.85-7.91\left(\mathrm{q}, J_{\mathrm{HH}}\right.$ $10 \mathrm{~Hz}, 2 \mathrm{H}), 4.00(\mathrm{~m}, 4 \mathrm{H}), 3.45$ (m, 4H), $3.31(\mathrm{~s}, 6 \mathrm{H}) .{ }^{13} \mathrm{C} \mathrm{NMR}\left(\mathrm{CDCl}_{3}, 125 \mathrm{MHz}\right): \delta(\mathrm{ppm})$ $160.00,134.02,133.96,1333.36,123.35,122.22,120.82,120.71,112.51,112.44,70.38,67.93$, 59.07. ${ }^{31} \mathrm{P} \mathrm{NMR}\left(\mathrm{CDCl}_{3}, 202 \mathrm{MHz}\right): \delta(\mathrm{ppm}) 19.2$.

\section{Preparation of bis(2-(2-methoxyethoxy)phenyl)phosphinic chloride (4b)}

A solution of $\mathbf{3 b}(3.2 \mathrm{mmol}, 1.15 \mathrm{~g})$ in thionyl chloride $(25 \mathrm{~mL})$ was heated to

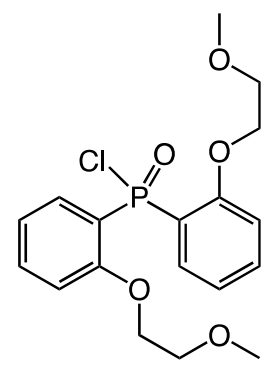
$80{ }^{\circ} \mathrm{C}$ under a flow of nitrogen gas for $3 \mathrm{~h}$. The solvent was removed under vacuum and washed with anhydrous pentane to give an off-white solid product in $89 \%$ yield. ${ }^{1} \mathrm{H}$ NMR $\left(\mathrm{CDCl}_{3}, 500 \mathrm{MHz}\right): \delta(\mathrm{ppm}) 8.05-8.10\left(\mathrm{dd}, J_{\mathrm{HH}}=10 \mathrm{~Hz}\right.$, $2 \mathrm{H}), 7.53\left(\mathrm{t}, J_{\mathrm{HH}}=5.0 \mathrm{~Hz}, 2 \mathrm{H}\right), 7.13\left(\mathrm{t}, J_{\mathrm{HH}}=5.0 \mathrm{~Hz}, 2 \mathrm{H}\right), 6.87-6.90\left(\mathrm{t}, J_{\mathrm{HH}}=\right.$ $5.0 \mathrm{~Hz}, 2 \mathrm{H}), 3.94(\mathrm{~m}, 4 \mathrm{H}), 3.27(\mathrm{~m}, 4 \mathrm{H}), 3.21(\mathrm{~s}, 6 \mathrm{H}) .{ }^{13} \mathrm{C} \mathrm{NMR}\left(\mathrm{CDCl}_{3}, 125\right.$ MHz): $\delta(\mathrm{ppm}) 159.58,134.57,133.62,133.56,123.24,122.21,120.85,120.73$, 112.39, 112.32, 70.26, 67.92, 59.06. ${ }^{31} \mathrm{P} \mathrm{NMR}\left(\mathrm{CDCl}_{3}, 202 \mathrm{MHz}\right): \delta$ (ppm) 39.2. 


\section{Preparation of ligand $6 \mathrm{~b}$}

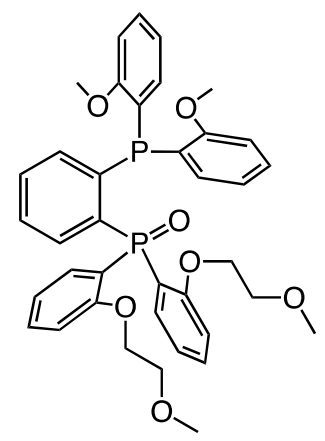

A $100 \mathrm{~mL}$ Schlenk flask was charged with $5(1.3 \mathrm{mmol}, 522 \mathrm{mg})$, tetramethyl ethylenediamine ( $1.95 \mathrm{mmol}, 227 \mathrm{~g}$ ), and $20 \mathrm{~mL}$ of anhydrous THF. The flask was cooled to $-78^{\circ} \mathrm{C}$ and $n \operatorname{BuLi}(1.6 \mathrm{M}$ in hexane, $1.95 \mathrm{mmol}, 1.22 \mathrm{~mL})$ was added dropwise via a syringe. The resulting yellow solution was stirred for 20 min. A solution containing $\mathbf{4 b}(1.3 \mathrm{mmol}, 500 \mathrm{mg})$ in $10 \mathrm{~mL}$ of anhydrous THF was added slowly via a syringe and stirred for $30 \mathrm{~min}$. The reaction mixture was warmed up to RT and stirred for $18 \mathrm{~h}$. The reaction mixture was quenched with water, extracted into dichloromethane $(3 \times 20 \mathrm{~mL})$, and then dried over anhydrous sodium sulfate. The solid obtained after evaporation was purified by silica gel column chromatography $\left(\mathrm{EtOAc} / \mathrm{MeOH} / \mathrm{CH}_{3} \mathrm{Cl}\right.$ 10:1:1, v/v) to afford $\mathbf{6 b}$ as a white solid in $43 \%$ yield. ${ }^{1} \mathrm{H} \mathrm{NMR}\left(\mathrm{CDCl}_{3}, 400 \mathrm{MHz}\right): \delta(\mathrm{ppm}) 8.26$ (br, 1H), 7.60-7.66 (m, 2H), 7.50 (br, 1H), 7.34-7.38 (m, 1H), 7.23-7.26 (br, 1H), 7.17-7.21 (m, 4H), 7.00-7.03 (m, 2H), 6.85-6.89 (br, 6H), 6.34-6.37 (br, 2H) ), 3.93 (br, 4H), 3.60 (s, 6H), 3.353.38 (br, 4H), $3.14(\mathrm{~s}, 6 \mathrm{H}) \cdot{ }^{13} \mathrm{C} \mathrm{NMR}\left(\mathrm{CDCl}_{3}, 101 \mathrm{MHz}\right): \delta(\mathrm{ppm}) 159.15,158.98,133.61,133.39$, 132.30, 132.27, 131.26, 131.24, 129.00, 127.81, 126.70, 126.56, 120.59, 119.51, 118.84, 118.23, 107.98, 68.75, 65.75, 58.73, 57.37, 53.49. ${ }^{31} \mathrm{P} \mathrm{NMR}\left(\mathrm{CDCl}_{3}, 243 \mathrm{MHz}\right): \delta(\mathrm{ppm}) 28.71$ and -30.64. ESI-MS(+) calc. for $\mathrm{C}_{38} \mathrm{H}_{40} \mathrm{O}_{7} \mathrm{P}_{2}[\mathrm{M}+\mathrm{H}]^{+}=671.2300$, found 671.2320 .

\section{Preparation of complex Ni3}

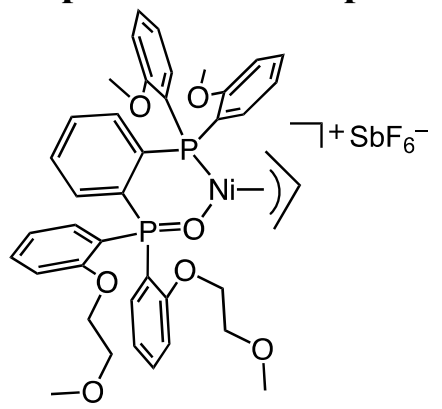

Inside the glovebox, a mixture of $\mathbf{6 b}(0.15 \mathrm{mmol}, 100 \mathrm{mg})$, silver hexafluoroantimonate(V) $(0.15 \mathrm{mmol}, 51 \mathrm{mg})$, and nickel allyl complex $[\mathrm{Ni}(\mathrm{allyl}) \mathrm{Cl}]_{2}(0.8 \mathrm{mmol}, 20 \mathrm{mg})$ were mixed in anhydrous dichloromethane and stirred at RT for $3 \mathrm{~h}$. The reaction mixture was then filtered and evaporated. The resulting solid was washed with anhydrous pentane $(3 \times 10 \mathrm{~mL})$ and dried under vacuum. The crude compound was recrystallized in dichloromethane layered with pentane to obtain a yellow solid in $75 \%$ yield. ${ }^{1} \mathrm{H} \mathrm{NMR}\left(\mathrm{CDCl}_{3}, 500 \mathrm{MHz}\right): \delta$ (ppm) 7.74-7.77 (m, 1H), 7.47-7.54 (br, 6H), 7.23-7.24 (br, 2H), 7.13-7.14 (br, 1H), 6.94-7.0 (br, 6H), 6.80 (br, 2H), 6.54 (br, 2H), 5.48 (br, 1H), 3.79-3.99 (m, $10 \mathrm{H}), 3.15-3.25(\mathrm{~m}, 10 \mathrm{H}), 2.10(\mathrm{br}, 2 \mathrm{H}), 1.71(\mathrm{br}, 2 \mathrm{H}) .{ }^{13} \mathrm{C}$ NMR $\left(\mathrm{CDCl}_{3}, 101 \mathrm{MHz}\right): 158.60$, 134.11, 132.12, 132.02, 131.91, 130.70, 128.64, 128.52, 119.81, 119.73, 119.56, 119.43, 112.18, 110.63, 109.61, 68.32, 66.07, 57.05, 54.14. $\left.{ }^{19} \mathrm{~F} \mathrm{NMR} \mathrm{(470} \mathrm{MHz,} \mathrm{CDCl}_{3}\right) \delta-62.27$ (s), -125 (br). ${ }^{31} \mathrm{P}$ NMR $\left(\mathrm{CDCl}_{3}, 202 \mathrm{MHz}\right): \delta(\mathrm{ppm}) 42.00$ and -1.87 . Analytical Calculated for $\mathrm{C}_{41} \mathrm{H}_{45} \mathrm{~F}_{6} \mathrm{NiO}_{7} \mathrm{P}_{2} \mathrm{Sb}$ : C, 48.94; H, 4.51. Found C, 46.63; H, 4.81. 


\section{METAL BINDING STUDIES}

\section{Method of Continuous Variation}

To perform these experiments, stock solutions of $\mathrm{Ni3}(6 \mathrm{mM}, 6 \mathrm{~mL})$ and $\mathrm{MBAr}^{\mathrm{F}}{ }_{4}(6 \mathrm{mM}, 6 \mathrm{~mL}$, $\mathrm{M}=\mathrm{Li}^{+}, \mathrm{Na}^{+}$) were prepared separately in $\mathrm{CDCl}_{3}$. Various amounts of each stock solution were added to an NMR tube so that a total volume of $1 \mathrm{~mL}$ was obtained. Ten different NMR samples were prepared, each containing a different ratio of Ni3 : M. The samples were recorded at RT by ${ }^{1} \mathrm{H}$ NMR spectroscopy (Figure S1 and S2). The hydrogen resonances centered at $~ 5.47 \mathrm{ppm}$ corresponding to the allyl group in Ni3 shift in the presence of alkali ions. The changes in the ${ }^{1} \mathrm{H}$ NMR signals of $\mathrm{H}_{\mathrm{a}}$ as a function of the mole fraction $\left(X_{\mathrm{Ni}}=[\mathbf{N i 3}] /\left([\mathrm{Ni3}]+\left[\mathrm{Na}^{+}\right]\right)\right.$of the nickel complexes are provided in Tables $\mathbf{S 1}$ and $\mathbf{S 2}$. 


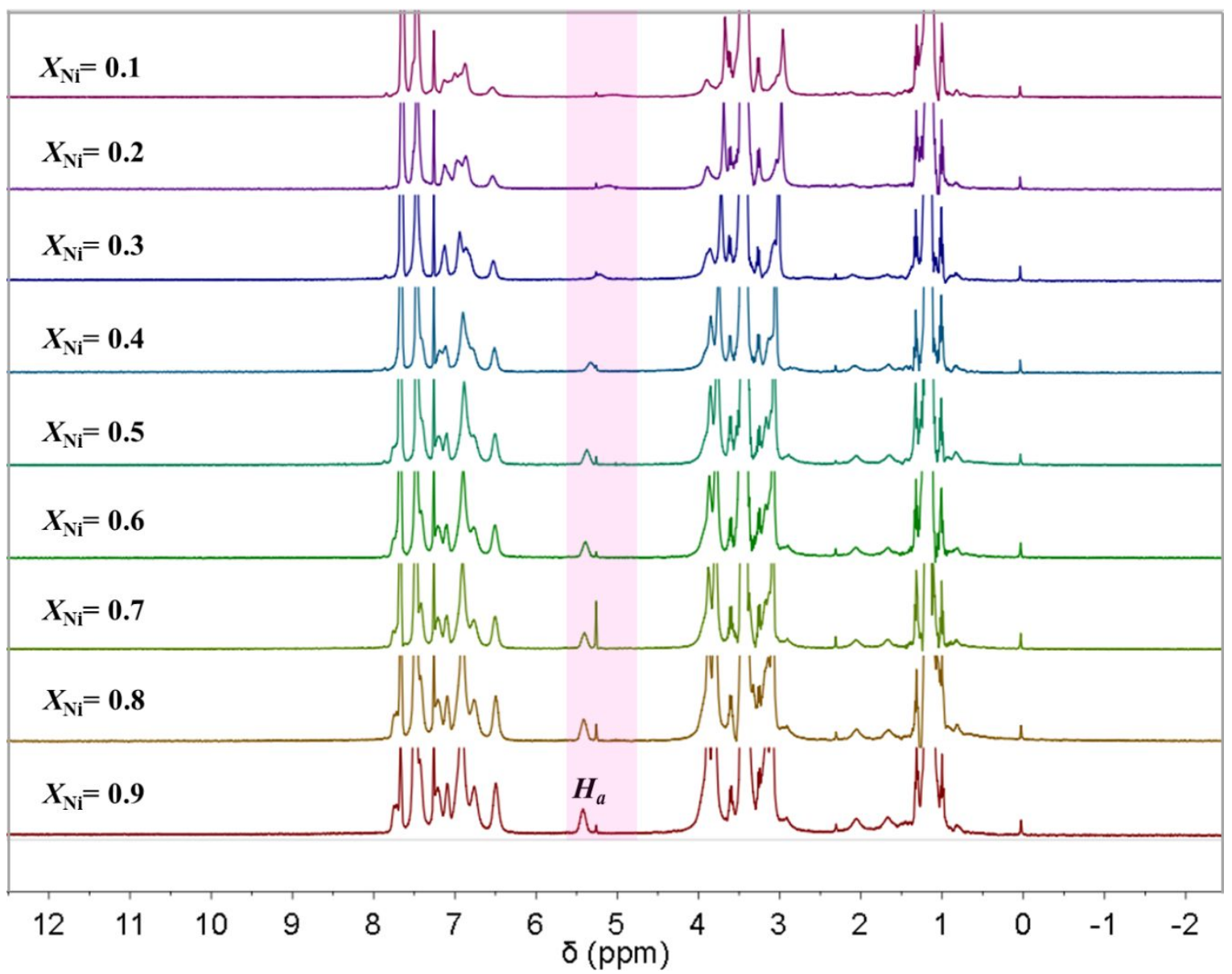

Figure S1. Job-Plot study: ${ }^{1} \mathrm{H}$ NMR spectra $\left(\mathrm{CDCl}_{3}, 600 \mathrm{MHz}\right)$ of samples containing $\mathrm{Ni3}$ and $\mathrm{NaBAr}_{4}{ }_{4}$ mixed in different ratios. The mole fraction of $\mathbf{N i 3}\left(X_{\mathrm{Ni}}\right)$ is defined as $[\mathrm{Ni3}] /\left([\mathrm{Ni3}]+\left[\mathrm{Na}^{+}\right]\right)$. The peaks labeled as $\mathrm{H}_{\mathrm{a}}$ are assigned to the hydrogen attached to the central carbon of the allyl group in Ni3. 
Table S1. NMR Job-Plot data for Ni3 and $\mathrm{NaBAr}_{4}^{\mathrm{F}}{ }^{a}$

\begin{tabular}{cccccc}
\hline $\mathbf{N i 3}(\mathrm{mL})$ & $\mathbf{N a}^{+}(\mathrm{mL})$ & $\left.[\mathbf{N i 3}] /(\mathbf{N i 3}]+\left[\mathbf{N a}{ }^{+}\right]\right)$ & $\begin{array}{c}\boldsymbol{\delta} \\
(\mathrm{ppm})^{b}\end{array}$ & $\begin{array}{c}\boldsymbol{\Delta} \boldsymbol{\delta} \\
(\mathrm{ppm})\end{array}$ & $(\boldsymbol{\Delta} \boldsymbol{\delta})[\mathbf{N i 3}] /\left([\mathbf{N i 3}]+\left[\mathbf{N a} \mathbf{a}^{+}\right]\right)$ \\
\hline 1 & 0 & 1 & 5.465 & 0 & 0 \\
0.9 & 0.1 & 0.9 & 5.451 & 0.014 & 0.0126 \\
0.8 & 0.2 & 0.8 & 5.435 & 0.03 & 0.0242 \\
0.7 & 0.3 & 0.7 & 5.415 & 0.05 & 0.0351 \\
0.6 & 0.4 & 0.6 & 5.390 & 0.075 & 0.0451 \\
0.5 & 0.5 & 0.5 & 5.356 & 0.109 & 0.0545 \\
0.4 & 0.6 & 0.4 & 5.315 & 0.15 & 0.0601 \\
0.3 & 0.7 & 0.3 & 5.277 & 0.188 & 0.0564 \\
0.2 & 0.8 & 0.2 & 5.260 & 0.205 & 0.0410 \\
0.1 & 0.9 & 0.1 & 5.260 & 0.205 & 0.0205 \\
0 & 1 & 0 & - & - & 0 \\
\hline${ }^{a}$ Concentrations of stock solutions: $[\mathbf{N i 3}]=6 \mathrm{mM}$ in $\mathrm{CDCl}_{3},\left[\mathrm{Na}^{+}\right]=6 \mathrm{mM}$ in $\mathrm{CDCl}_{3} / \mathrm{Et}_{2} \mathrm{O}{ }^{b}{ }^{b}$ The peaks listed \\
correspond to $H_{a}$ in Figure S1.
\end{tabular}




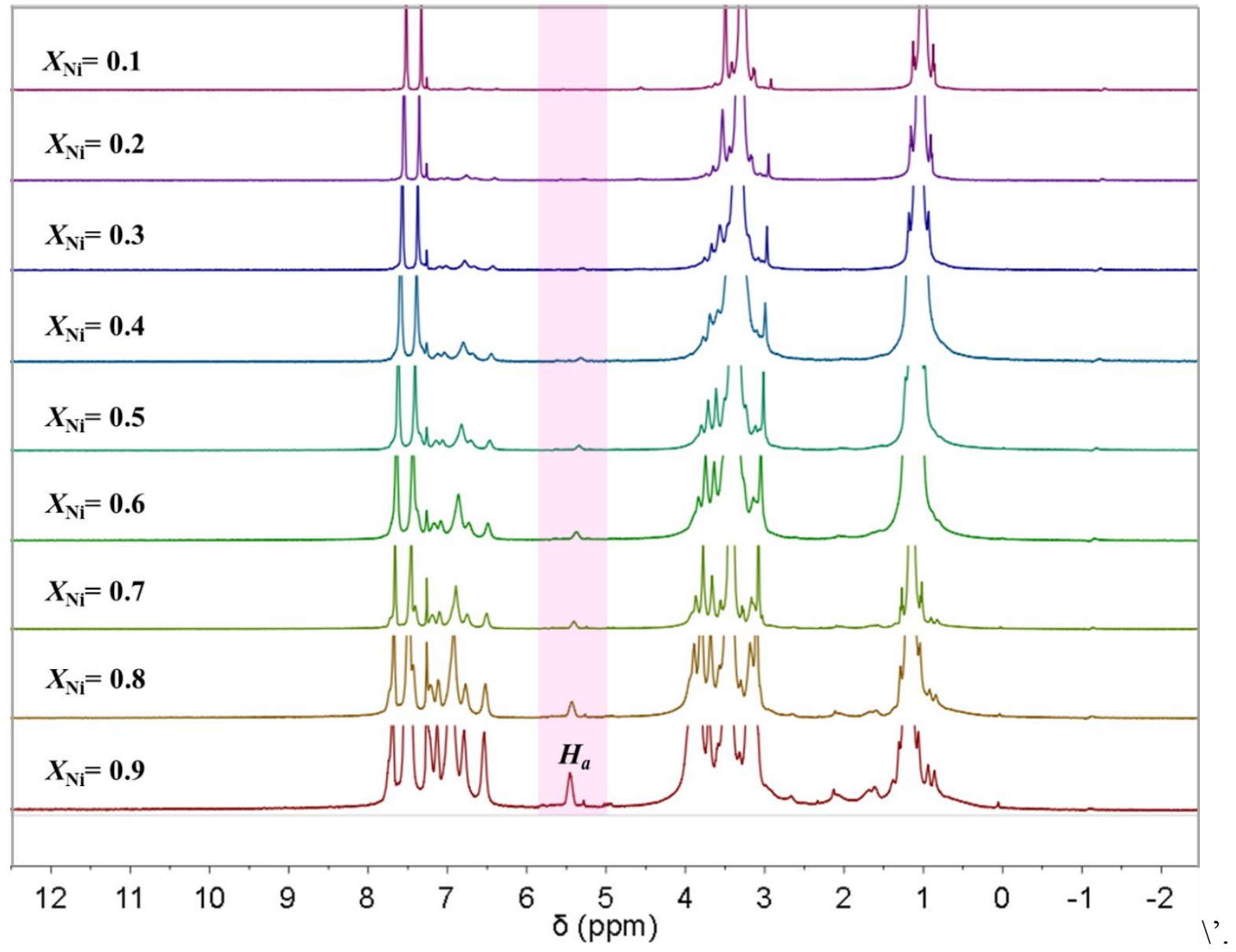

Figure S2. Job-Plot study: ${ }^{1} \mathrm{H}$ NMR spectra $\left(\mathrm{CDCl}_{3}, 600 \mathrm{MHz}\right)$ of samples containing Ni3 and $\mathrm{LiBAr}_{4}{ }_{4}$ mixed in different ratios. The mole fraction of $\mathbf{N i 3}\left(\mathrm{X}_{\mathrm{Ni}}\right)$ is defined as $[\mathrm{Ni3}] /\left([\mathbf{N i}]+\left[\mathrm{Li}^{+}\right]\right)$. The peaks labeled as $\mathrm{H}_{\mathrm{a}}$ was assigned to the hydrogen attached to the central carbon of the allyl group in Ni3. 
Table S2. NMR Job-Plot data for Ni3 and $\mathrm{LiBAr}_{4}^{\mathrm{F}}{ }^{\mathrm{a}}$

\begin{tabular}{|c|c|c|c|c|c|}
\hline $\mathbf{N i 3}(\mathrm{mL})$ & $\mathbf{L i}^{+}(\mathrm{mL})$ & {$[\mathbf{N i 3}] /\left([\mathbf{N i 3}]+\left[\mathrm{Na}^{+}\right]\right)$} & $\begin{array}{c}\boldsymbol{\delta} \\
(\mathrm{ppm})^{b}\end{array}$ & $\begin{array}{c}\Delta \boldsymbol{\delta} \\
(\mathrm{ppm})\end{array}$ & $(\Delta \delta)[\mathrm{Ni3}] /\left([\mathrm{Ni3}]+\left[\mathrm{Li}^{+}\right]\right)$ \\
\hline 1 & 0 & 1 & 5.465 & 0 & 0 \\
\hline 0.9 & 0.1 & 0.9 & 5.451 & 0.0144 & 0.0144 \\
\hline 0.8 & 0.2 & 0.8 & 5.427 & 0.0305 & 0.0320 \\
\hline 0.7 & 0.3 & 0.7 & 5.401 & 0.0498 & 0.0462 \\
\hline 0.6 & 0.4 & 0.6 & 5.369 & 0.0752 & 0.0588 \\
\hline 0.5 & 0.5 & 0.5 & 5.341 & 0.1017 & 0.0630 \\
\hline 0.4 & 0.6 & 0.4 & 5.316 & 0.1146 & 0.0604 \\
\hline 0.3 & 0.7 & 0.3 & 5.301 & 0.1417 & 0.0498 \\
\hline 0.2 & 0.8 & 0.2 & 5.284 & 0.1435 & 0.0366 \\
\hline 0.1 & 0.9 & 0.1 & 5.263 & 0.1439 & 0.0204 \\
\hline 0 & 1 & 0 & - & - & 0 \\
\hline
\end{tabular}




\section{Metal Titration and Fitting}

To calculate the association constants corresponding to the interactions between host $\mathbf{N i 3}$ and guest $\operatorname{MBAr}_{4}{ }_{4}\left(\mathrm{M}=\mathrm{Li}^{+}, \mathrm{Na}^{+}\right),{ }^{1} \mathrm{H}$ NMR titrations were carried out using stock solutions containing a constant amount of Ni3 $(20 \mu \mathrm{M})$ while adding incremental quantities of $\mathrm{NaBAr}_{4}^{\mathrm{F}}$ or $\operatorname{LiBAr}_{4}^{\mathrm{F}}$ (Figure S3 and S4). In particular, the change in the chemical shift of the allylic proton resonances was monitored. The changes in the ${ }^{1} \mathrm{H}$ NMR signal of $\mathrm{H}_{\mathrm{a}}$ are summarized in Tables S3 and S4. The data obtained were used to determine the association constant $(K)$ by a global fitting analysis to different binding models $(1: 1,2: 1$, or 1:2 nickel to alkali ion) according to reported equations in literature and using Bindfit. ${ }^{8-10}$ To perform the BindFit analysis, an input file was uploaded and different NMR "fitters" were selected. Initial $K$ guess values were used to initiate the fit using either the Nelder-Mead or L-BFGS-B methods. Different $K$ guesses were tried until the fit gave binding constants that have positive values. The URLs for the BindFit results are provided below:

Ni3/ $/ \operatorname{LiBAr}_{4}{ }_{4}$

1:1 fit: http://app.supramolecular.org/bindfit/view/14362288-b2c0-4c36-a2fe-456e04f565e7

1:2 fit: http://app.supramolecular.org/bindfit/view/5080b5e9-a250-4489-ae7c-56c6c5d9f10d

2:1 fit: http://app.supramolecular.org/bindfit/view/2606c9b7-3cdf-42fb-8e7f-28e008dfb24c

$\mathrm{Ni3} / \mathrm{NaBAr}_{4}{ }_{4}$

1:1 fit: http://app.supramolecular.org/bindfit/view/0e1944e8-b25f-4a39-97d2-d3b648ff27b1

1:2 fit: http://app.supramolecular.org/bindfit/view/e9a8d5dd-1dfe-483e-abe6-753ce100c55d

2:1 fit: http://app.supramolecular.org/bindfit/view/48e5d548-bcb3-4427-bdbe-5e4472a267d9 
A. Equations for 1:1 host:guest equilibria

Equation S1. General expression for equilibrium constant.

$$
K_{\mathrm{a}}=[\mathrm{HG}] /[\mathrm{H}][\mathrm{G}]
$$

Equation S2. Expression for free guest concentration.

$$
[\mathrm{G}]=0.5\left(\mathrm{G}_{0}-\mathrm{H}_{0}-1 / K_{\mathrm{a}}\right)-\left(\left(\mathrm{G}_{0}-\mathrm{H}_{0}-1 / K_{\mathrm{a}}\right)^{2}+4\left(\mathrm{G}_{0} / K_{\mathrm{a}}\right)\right)^{0.5}
$$

Equation S3. Expression for complex guest concentration.

$$
[\mathrm{HG}]=0.5\left(\mathrm{G}_{0}+\mathrm{H}_{0}+1 / K_{\mathrm{a}}\right)-\left(\left(\mathrm{G}_{0}+\mathrm{H}_{0}+1 / K_{\mathrm{a}}\right)^{2}+4\left[\mathrm{H}_{0}\right]\left[\mathrm{G}_{0}\right]\right)^{0.5}
$$

Equation S4. Change in mole fraction dependent chemical shift up on titration

$$
\Delta \delta=\delta_{\Delta \mathrm{HG}}\left([\mathrm{HG}] /\left[\mathrm{H}_{0}\right]\right)
$$

B. Equations for 1:2 host:guest equilibria

Equation S5. General expression for equilibrium constants.

$$
K_{1}=[\mathrm{HG}] /[\mathrm{H}][\mathrm{G}] \text { and } K_{2}=\left[\mathrm{HG}_{2}\right] /[\mathrm{H}][\mathrm{G}]
$$

Equation S6. Expression for free guest concentration.

$$
[\mathrm{G}]^{3}\left(\mathrm{~K}_{1} \mathrm{~K}_{2}\right)+[\mathrm{G}]^{2}\left(K_{1}\left(2 K_{2}[\mathrm{H}]_{0}-K_{2}[\mathrm{G}]_{0}+1\right)\right)+[\mathrm{G}]\left(K_{1}\left([\mathrm{H}]_{0}-[\mathrm{G}]_{0}+1\right)\right)-[\mathrm{G}]_{0}=0
$$

Equation S7. Change in mole fraction dependent chemical shift up on titration.

$$
\Delta \delta=\left(\delta_{\Delta \mathrm{HG}}[\mathrm{H}]_{0} K_{1}[\mathrm{G}]+\delta_{\Delta \mathrm{HG} 2} K_{1} K_{1}[\mathrm{G}]^{2}\right) /\left(1+K_{1}[\mathrm{G}]+K_{1} K_{1}[\mathrm{G}]^{2}\right)
$$


C. Equations for 2:1 host:guest equilibria

Equation S8. General expression for equilibrium constants.

$$
K_{1}=[\mathrm{HG}] /[\mathrm{H}][\mathrm{G}] \text { and } K_{2}=\left[\mathrm{H}_{2} \mathrm{G}\right] /[\mathrm{H}][\mathrm{G}]
$$

Equation S9. Expression for free guest concentration.

$$
[\mathrm{H}]^{3}\left(\mathrm{~K}_{1} \mathrm{~K}_{2}\right)+[\mathrm{H}]^{2}\left(K_{1}\left(2 K_{2}[\mathrm{G}]_{0}-K_{2}[\mathrm{H}]_{0}+1\right)\right)+[\mathrm{H}]\left(K_{1}\left([\mathrm{G}]_{0}-[\mathrm{H}]_{0}+1\right)\right)-[\mathrm{H}]_{0}=0
$$

Equation S10. Change in mole fraction dependent chemical shift up on titration.

$$
\Delta \delta=\left(\delta_{\Delta \mathrm{HG}}[\mathrm{G}]_{0} K_{1}[\mathrm{H}]+\delta_{2 \Delta \mathrm{H} 2 \mathrm{G}}[\mathrm{G}]_{0} K_{1} K_{1}[\mathrm{H}]^{2}\right) /[\mathrm{H}]_{0}\left(1+K_{1}[\mathrm{H}]+K_{1} K_{1}[\mathrm{H}]^{2}\right)
$$

Where:

$\mathrm{H}=$ the mononickel $\mathbf{N i 3}$ complex

$\mathrm{G}=\operatorname{MBAr}_{4}{ }_{4}\left(\mathrm{M}=\mathrm{Li}^{+}, \mathrm{Na}^{+}\right)$

$\mathrm{HG}=$ the bimetallic $(\mathbf{N i 3})_{1}(\mathrm{M})_{1}$ complex $\left(\mathrm{M}=\mathrm{Li}^{+}, \mathrm{Na}^{+}\right)$

$\mathrm{HG}_{2}=$ the trimetallic $(\mathbf{N i 3})_{1}(\mathrm{M})_{2}$ complex $\left(\mathrm{M}=\mathrm{Li}^{+}, \mathrm{Na}^{+}\right)$

$\mathrm{H}_{2} \mathrm{G}=$ the trimetallic $(\mathbf{N i 3})_{2}(\mathrm{M})_{1}$ complex $\left(\mathrm{M}=\mathrm{Li}^{+}, \mathrm{Na}^{+}\right)$

$[\mathrm{H}]_{0}=$ the initial concentration of $\mathbf{N i 3}$

$[\mathrm{G}]_{0}=$ the total added amount of $\mathrm{MBAr}_{4}{ }_{4}\left(\mathrm{M}=\mathrm{Li}^{+}, \mathrm{Na}^{+}\right)$at each point in the titration

$\Delta \delta=$ the chemical shift change of $\mathrm{H}_{\mathrm{a}}$ in $\mathbf{N i 3}$ based on ${ }^{1} \mathrm{H}$ NMR spectroscopy measurements

$\delta_{\Delta \mathrm{HG}}=\delta_{\mathrm{HG}}-\delta_{\mathrm{H}}$

$\delta_{2 \Delta \mathrm{H} 2 \mathrm{G}}=\delta_{\mathrm{H} 2 \mathrm{G}}-2 \delta_{\mathrm{H}}$ 


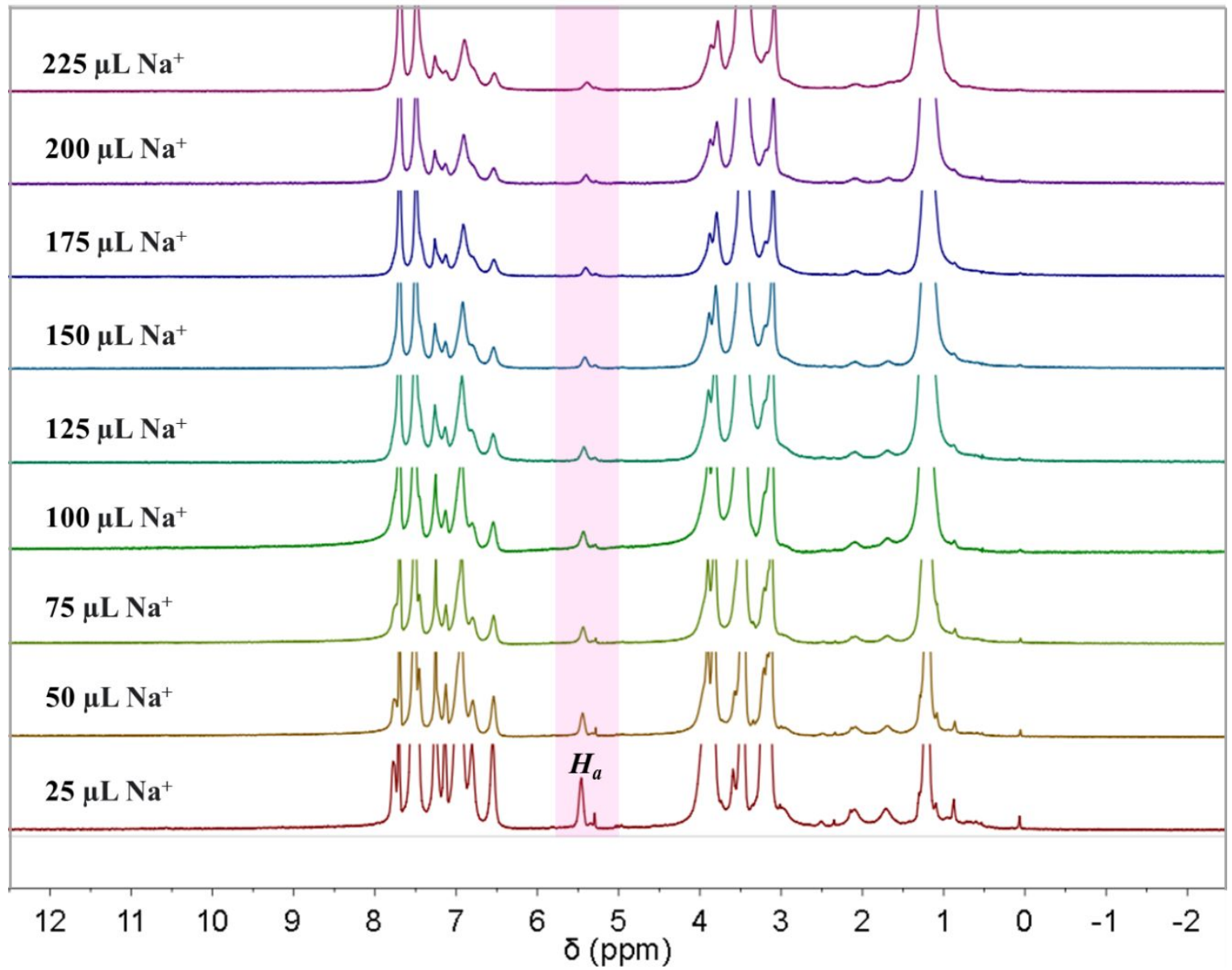

Figure S3. Binding constant study: ${ }^{1} \mathrm{H} \mathrm{NMR}$ spectra $\left(\mathrm{CDCl}_{3}, 600 \mathrm{MHz}\right)$ of samples containing constant amount of $\mathrm{Ni3}(0.029 \mathrm{M})$ and different ratios of $\mathrm{NaBAr}_{4}$ (stock solution $\left.0.162 \mathrm{M}\right)$. The peaks labeled as $\mathrm{H}_{\mathrm{a}}$ was assigned to the hydrogen attached to the central carbon of the allyl group in Ni3.

Table S3. NMR Titration Data for Reaction of Ni3 with $\mathrm{NaBAr}_{4}$

\begin{tabular}{cccl}
\hline $\mathbf{N i 3}(\mathrm{M})$ & $\mathbf{N a}^{+}(\mathrm{M})$ & {$\left[\mathrm{Na}^{+}\right] /[\mathbf{N i 3}]$ equiv. } & $\boldsymbol{\delta}(\mathrm{ppm})$ \\
\hline 0.029199 & 0.018059 & 0.62 & 5.448 \\
0.029199 & 0.036117 & 1.2 & 5.440 \\
0.029199 & 0.054176 & 1.8 & 5.430 \\
0.029199 & 0.072235 & 2.4 & 5.423 \\
0.029199 & 0.090293 & 3.1 & 5.414 \\
0.029199 & 0.108352 & 3.7 & 5.397 \\
0.029199 & 0.126411 & 4.3 & 5.393 \\
0.029199 & 0.14447 & 4.9 & 5.385 \\
0.029199 & 0.16253 & 5.5 & 5.376
\end{tabular}




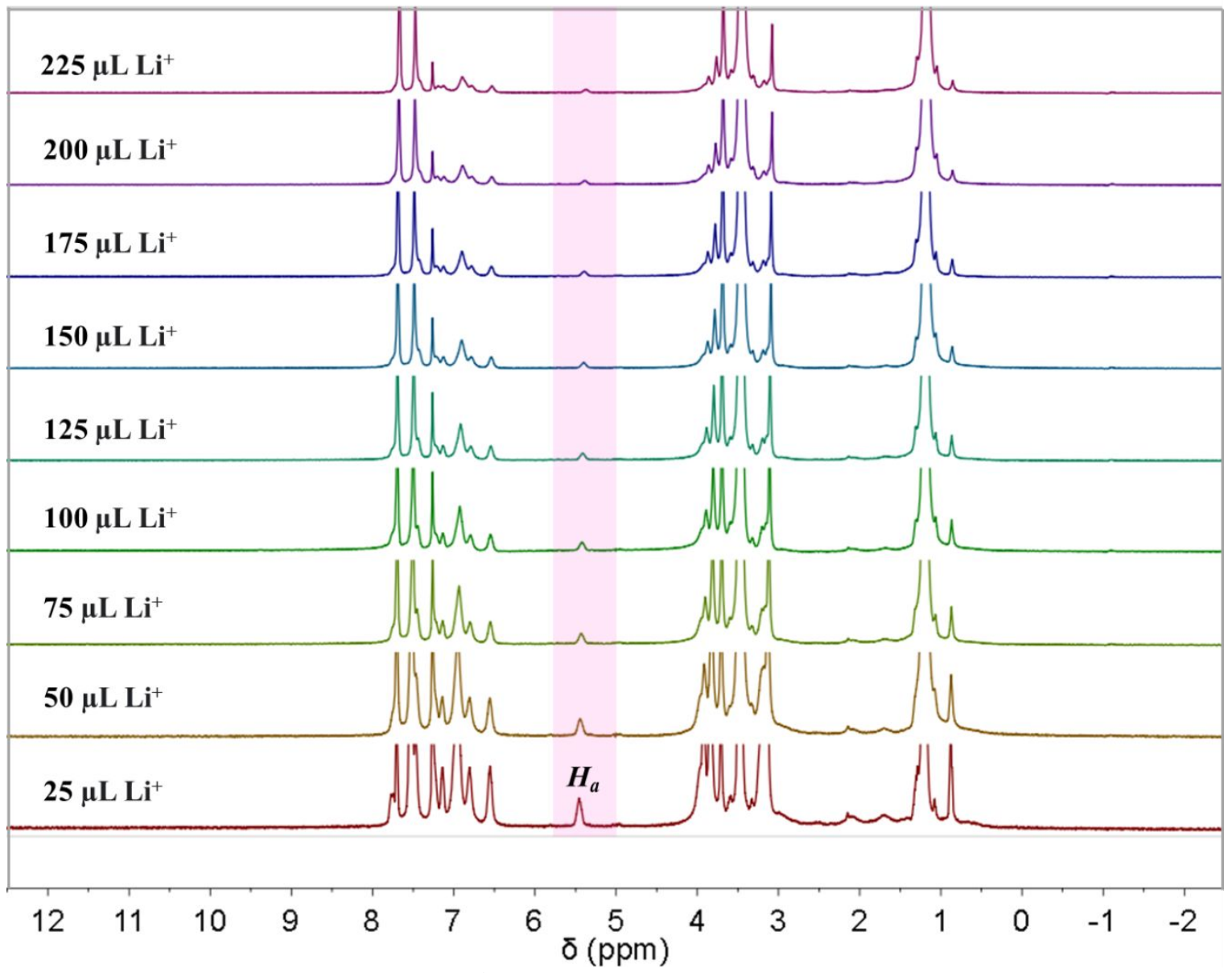

Figure S4. Binding constant study: ${ }^{1} \mathrm{H}$ NMR spectra $\left(\mathrm{CDCl}_{3}, 600 \mathrm{MHz}\right)$ of samples containing constant amount of $\mathrm{Ni3}(0.029 \mathrm{M})$ and different ratios of $\mathrm{LiBAr}_{4}$ (stock solution $\left.0.162 \mathrm{M}\right)$. The peaks labeled as $\mathrm{H}_{\mathrm{a}}$ was assigned to the hydrogen attached to the central carbon of the allyl group in Ni3.

Table S4. NMR Titration Data for Reaction of Ni3 with $\mathrm{LiBAr}_{4}$

\begin{tabular}{cccc}
\hline $\mathbf{N i 3}(\mathrm{M})$ & $\mathbf{L i}^{+}(\mathrm{M})$ & {$\left[\mathrm{Li}^{+}\right] /[\mathbf{N i 3}]$ equiv. } & $\boldsymbol{\delta}(\mathrm{ppm})$ \\
\hline 0.029199 & 0.018059 & 0.62 & 5.455 \\
0.029199 & 0.036117 & 1.2 & 5.444 \\
0.029199 & 0.054176 & 1.8 & 5.431 \\
0.029199 & 0.072235 & 2.4 & 5.421 \\
0.029199 & 0.090293 & 3.1 & 5.412 \\
0.029199 & 0.108352 & 3.7 & 5.398 \\
0.029199 & 0.126411 & 4.3 & 5.391 \\
0.029199 & 0.14447 & 4.9 & 5.388
\end{tabular}




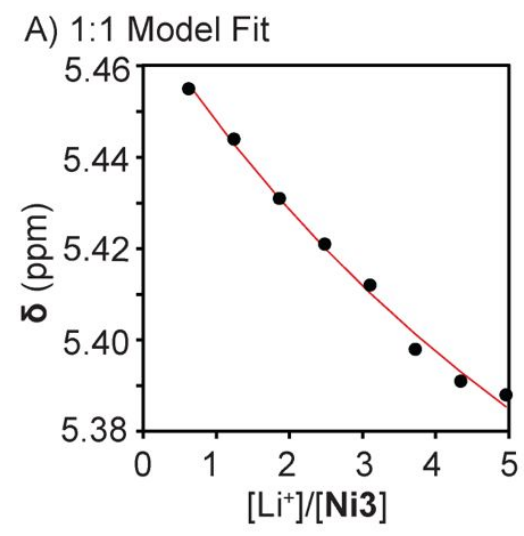

$K=3.6 \mathrm{M}^{-1}( \pm 5.9 \%)$
B) $2: 1$ Model Fit

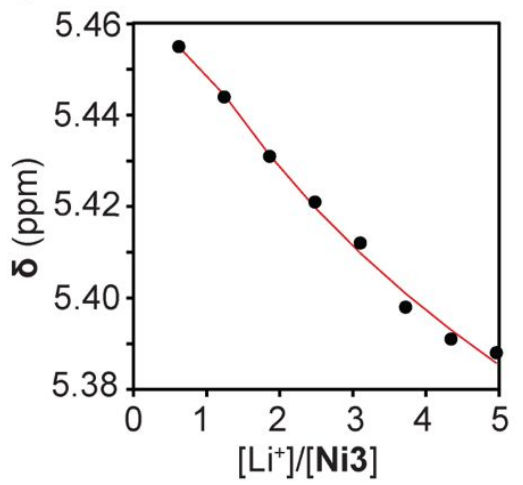

$K_{11}=51.7 \mathrm{M}^{-1}( \pm 43.0 \%)$

$K_{12}=996.0 \mathrm{M}^{-1}( \pm 35.4 \%)$
C) $1: 2$ Model Fit

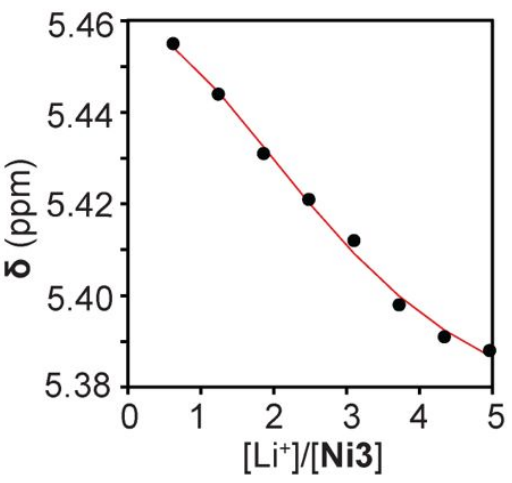

$K_{11}=0.1 \mathrm{M}^{-1}( \pm 111.4 \%)$
$K_{12}=6749.1 \mathrm{M}^{-1}( \pm 43.4 \%)$

Figure S5. BindFit global analysis of the Ni3/LiBAr ${ }_{4} \mathrm{NMR}$ titration data. The plots show the data fit to a 1:1 (A), 2:1 (B), and 1:2 (C) nickel-to-lithium binding model and their corresponding binding constants. The raw data is shown as black dots and the fits are shown as red lines. Based on the large $\%$ errors in the binding constants, the 1:2 model was ruled out. Considering both the Job Plot for $\mathbf{N i 3} / \operatorname{LiBAr}^{\mathrm{F}}{ }_{4}$ (see Figure 3B) and these results, the 1:1 model was deemed to be most consistent with the experimental data.

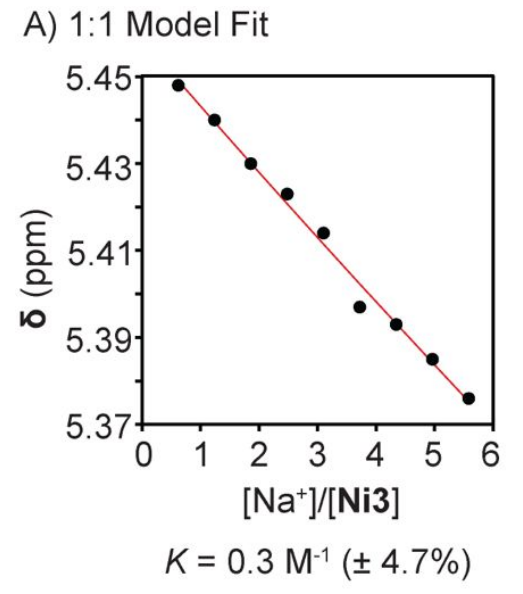

B) 2:1 Model Fit

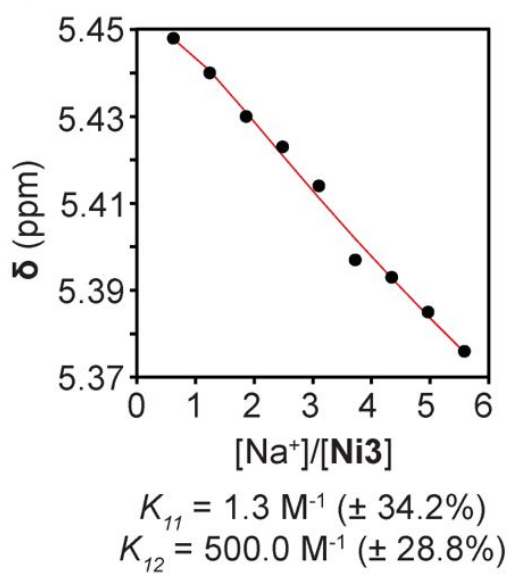

C) 1:2 Model Fit

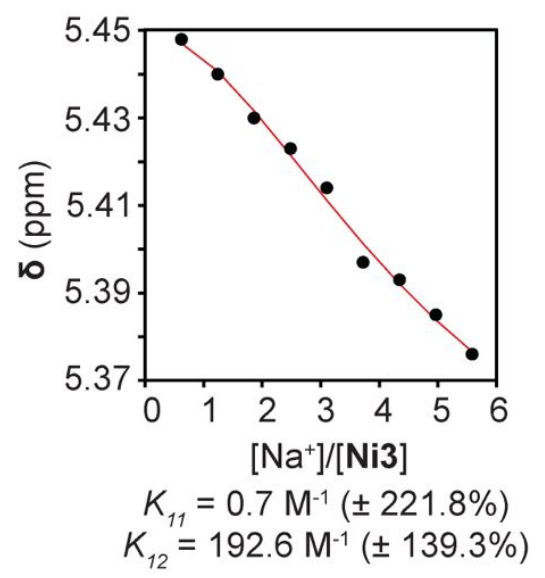

Figure S6. BindFit global analysis of the Ni3/NaBAr${ }_{4}{ }_{4} \mathrm{NMR}$ titration data. The plots show the data fit to a 1:1 (A), 2:1 (B), and 1:2 (C) nickel-to-sodium binding model and their corresponding binding constants. The raw data is shown as black dots and the fits are shown as red lines. Based on the large $\%$ errors in the binding constants, the 1:2 model was ruled out. Considering both the Job Plot for $\mathrm{Ni3} / \mathrm{NaBAr}^{\mathrm{F}}{ }_{4}$ (see Figure $3 \mathrm{~B}$ ) and these results, the 2:1 model was deemed to be most consistent with the experimental data. 
Table S5. Binding Constants Obtained from Global Fitting of NMR Titration Data ${ }^{a}$

\begin{tabular}{|c|c|c|c|c|c|}
\hline \multirow[b]{2}{*}{ Host/Guest } & \multirow{2}{*}{$\begin{array}{c}\text { 1:1 Model } \\
K\left(\mathrm{M}^{-1}\right)\end{array}$} & \multicolumn{2}{|c|}{ 2:1 Model } & \multicolumn{2}{|c|}{ 1:2 Model } \\
\hline & & $K_{11}\left(\mathrm{M}^{-1}\right)$ & $K_{21}\left(\mathrm{M}^{-1}\right)$ & $K_{11}\left(\mathrm{M}^{-1}\right)$ & $K_{12}\left(\mathrm{M}^{-1}\right)$ \\
\hline $\mathrm{Ni3} / \mathrm{LiBAr}^{\mathrm{F}}{ }_{4}$ & $3.6( \pm 5.9 \%)$ & $51.7( \pm 43.0 \%)$ & $996.0( \pm 35.4 \%)$ & $0.1( \pm 111.4 \%)$ & $6749( \pm 43.4 \%)$ \\
\hline $\mathrm{Ni3} / \mathrm{NaBAr}_{4}$ & $0.3( \pm 4.7 \%)$ & $1.3( \pm 34.2 \%)$ & $500.0( \pm 28.8 \%)$ & $0.7( \pm 221.8 \%)$ & $192.6( \pm 139.3 \%)$ \\
\hline
\end{tabular}




\section{CHARACTERIZATION DATA}

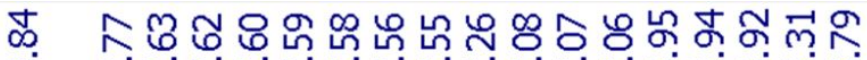

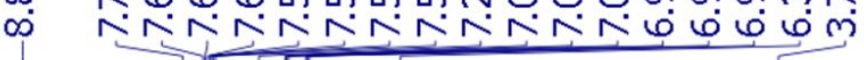
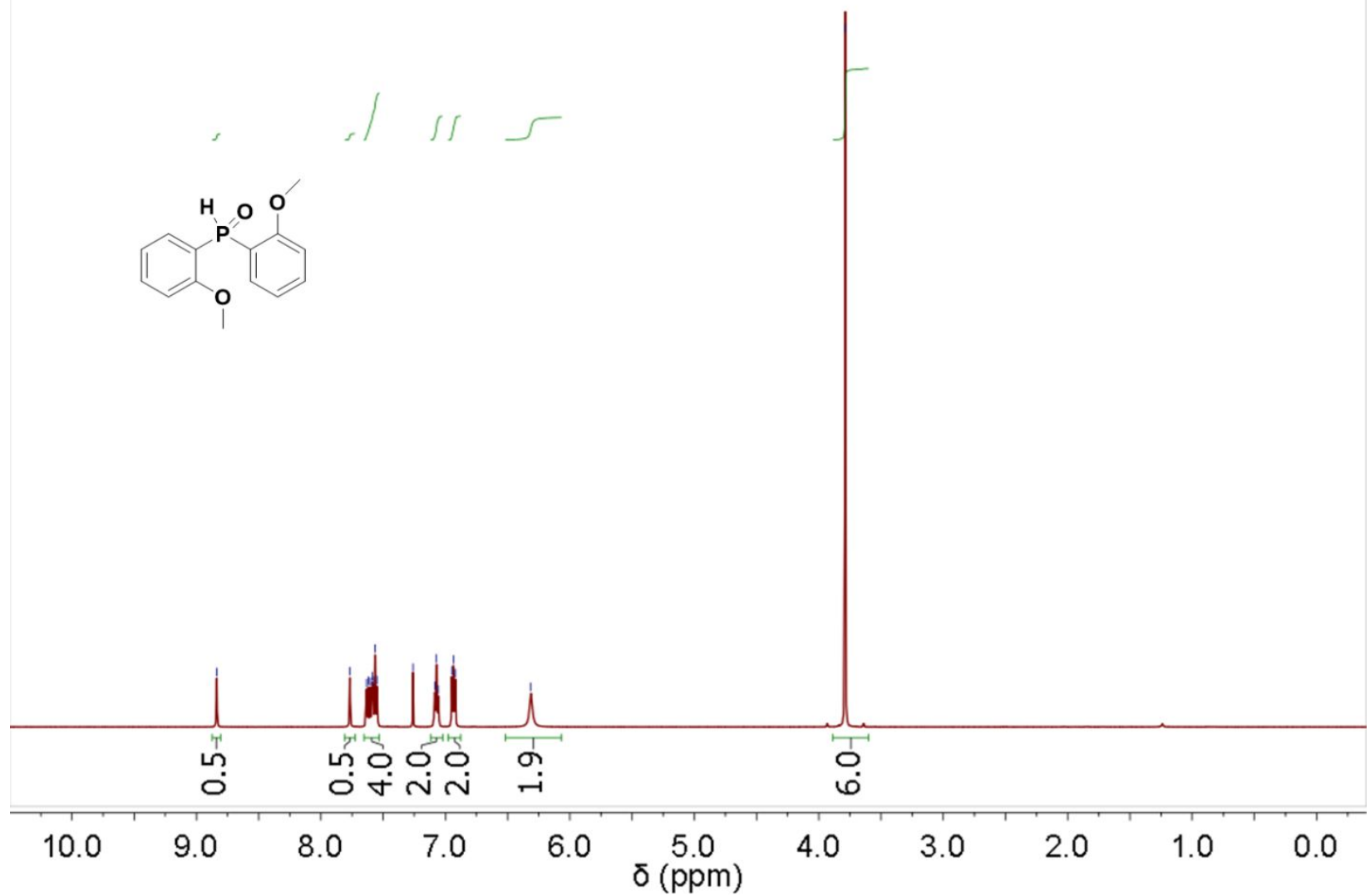

Figure S7. ${ }^{1} \mathrm{H}$ NMR spectrum $\left(\mathrm{CDCl}_{3}, 500 \mathrm{MHz}\right)$ of $\mathbf{2 a}$. 
$\stackrel{\circ}{\circ}$
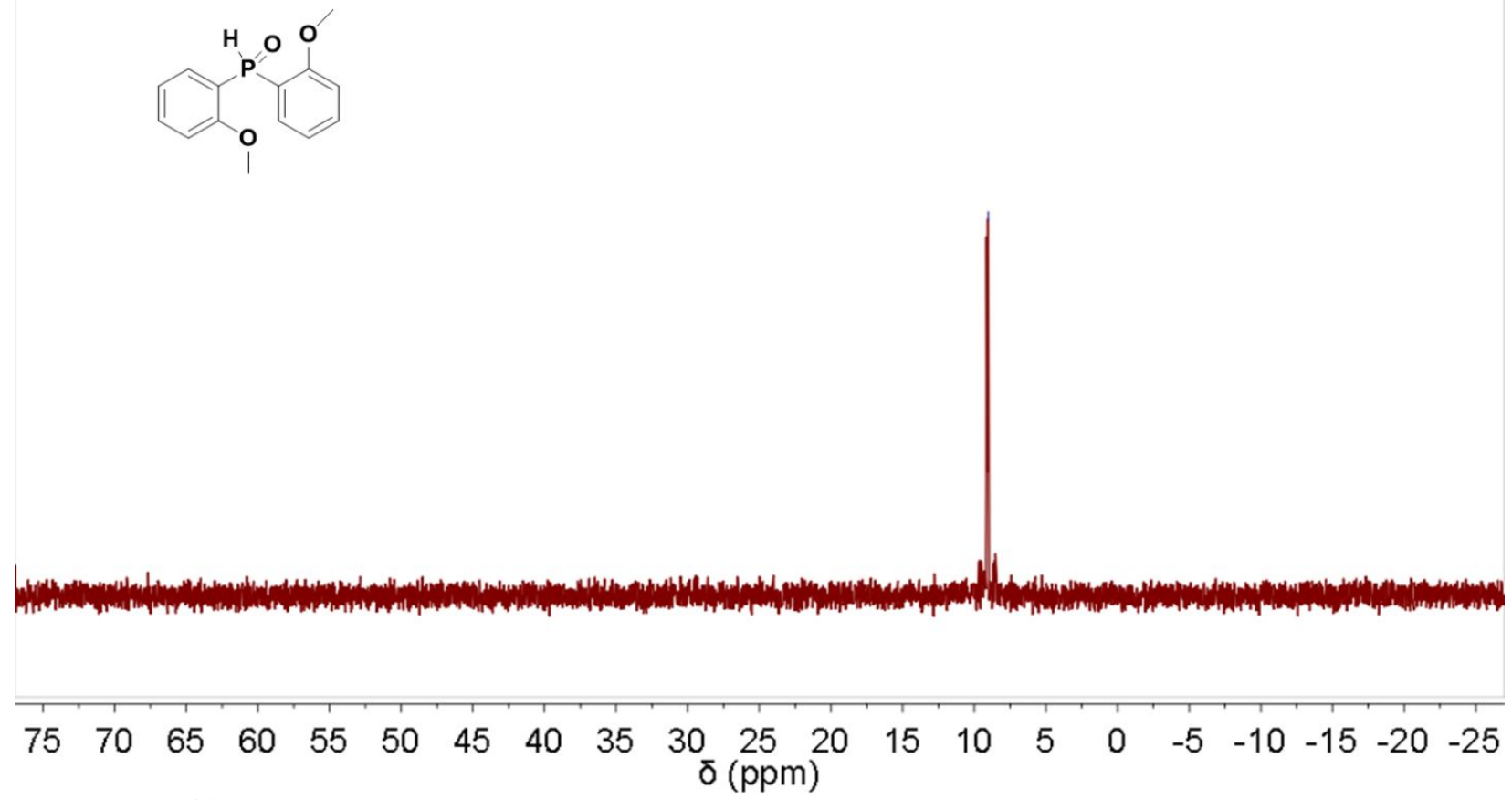

Figure S8. ${ }^{31} \mathrm{P}$ NMR spectrum $\left(\mathrm{CDCl}_{3}, 243 \mathrm{MHz}\right)$ of $\mathbf{2 a}$. 

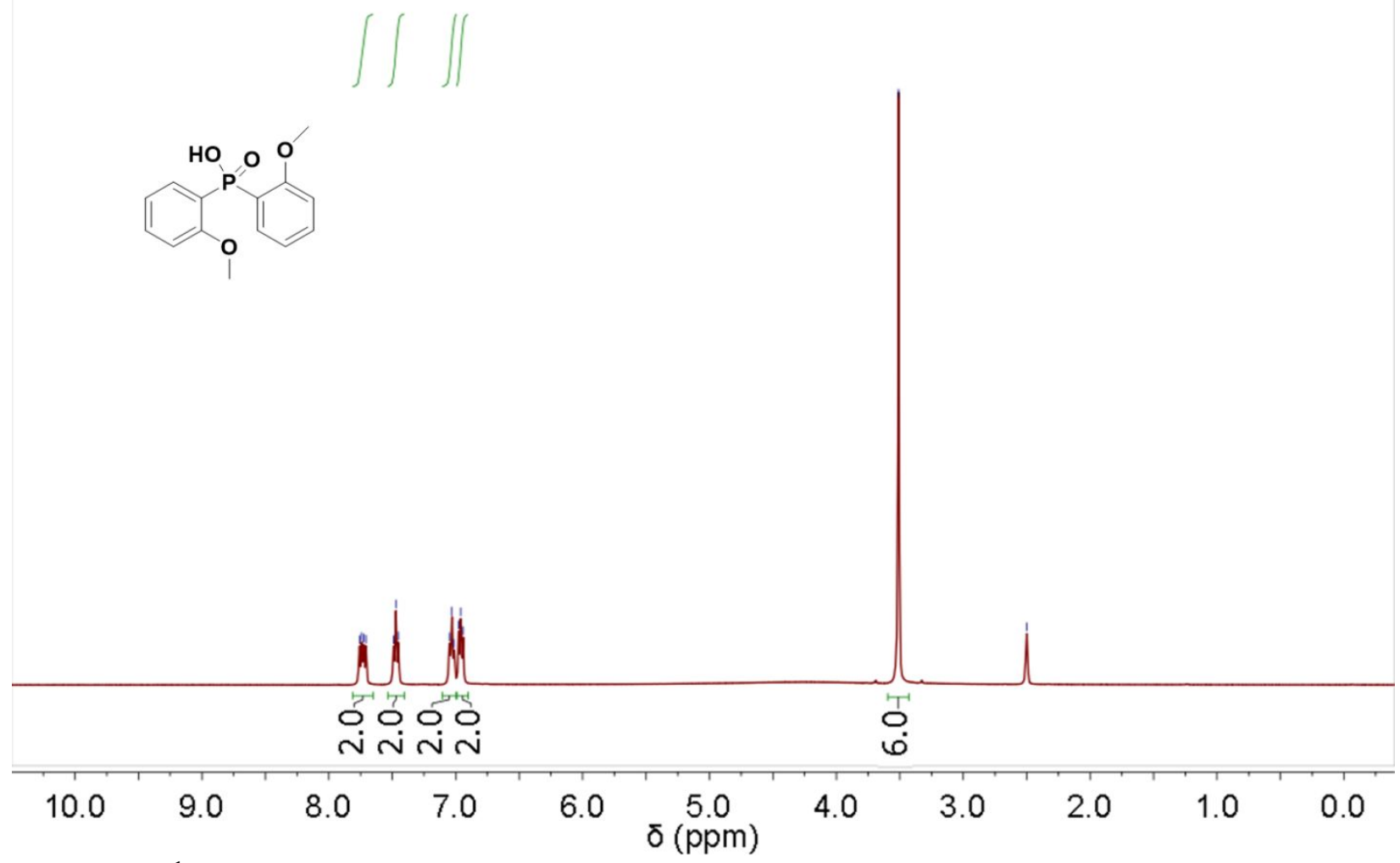

Figure S9. ${ }^{1} \mathrm{H}$ NMR spectrum $\left(\mathrm{CDCl}_{3}, 400 \mathrm{MHz}\right)$ of $\mathbf{3 a}$. 


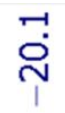
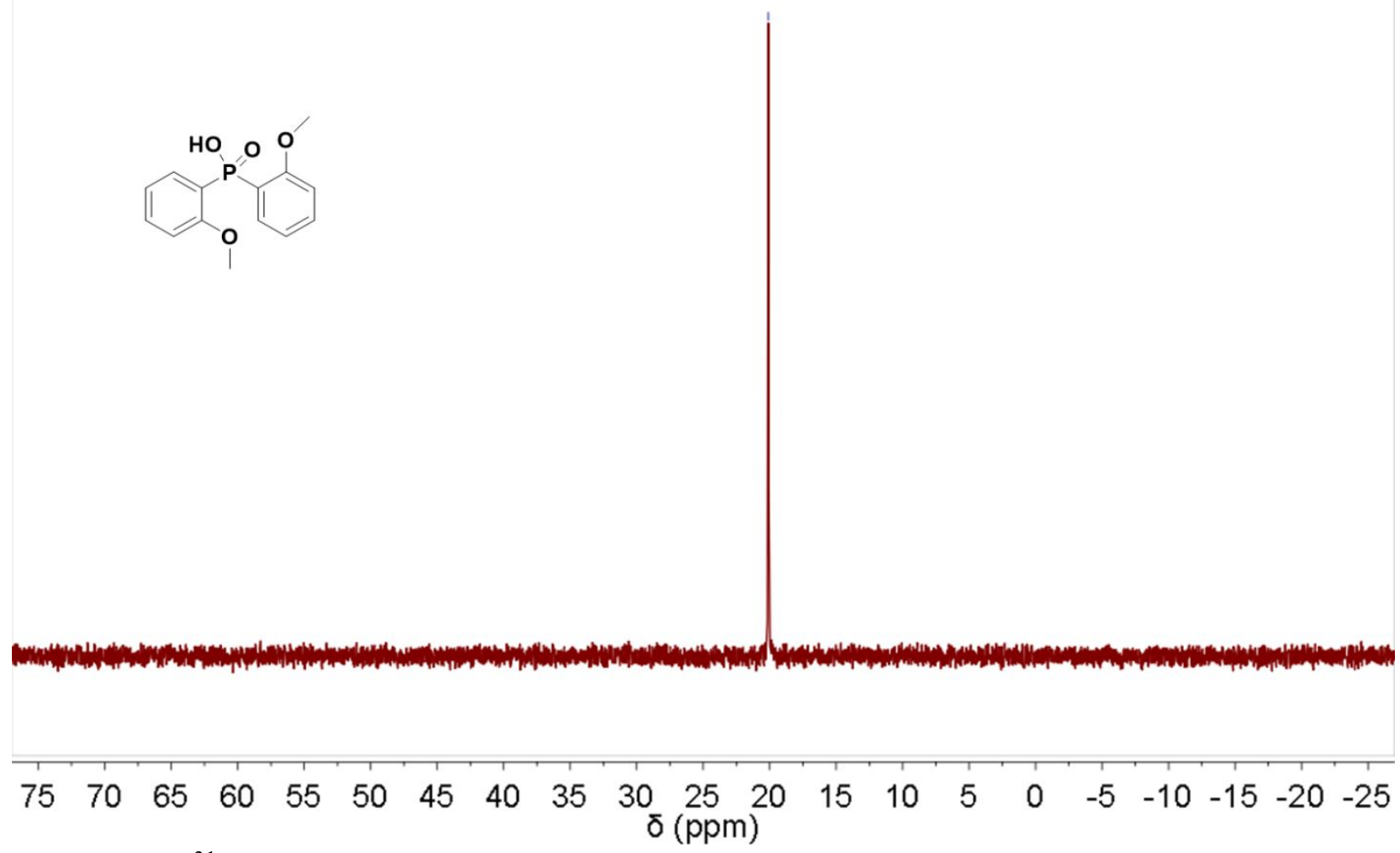

Figure S10. ${ }^{31} \mathrm{P}$ NMR spectrum $\left(\mathrm{CDCl}_{3}, 243 \mathrm{MHz}\right)$ of $\mathbf{3 a}$. 


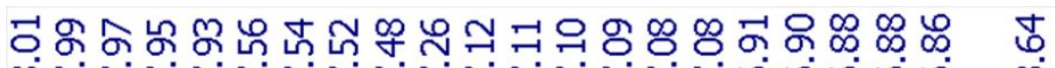

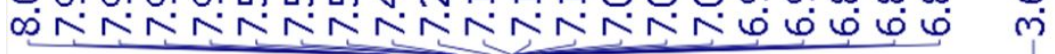

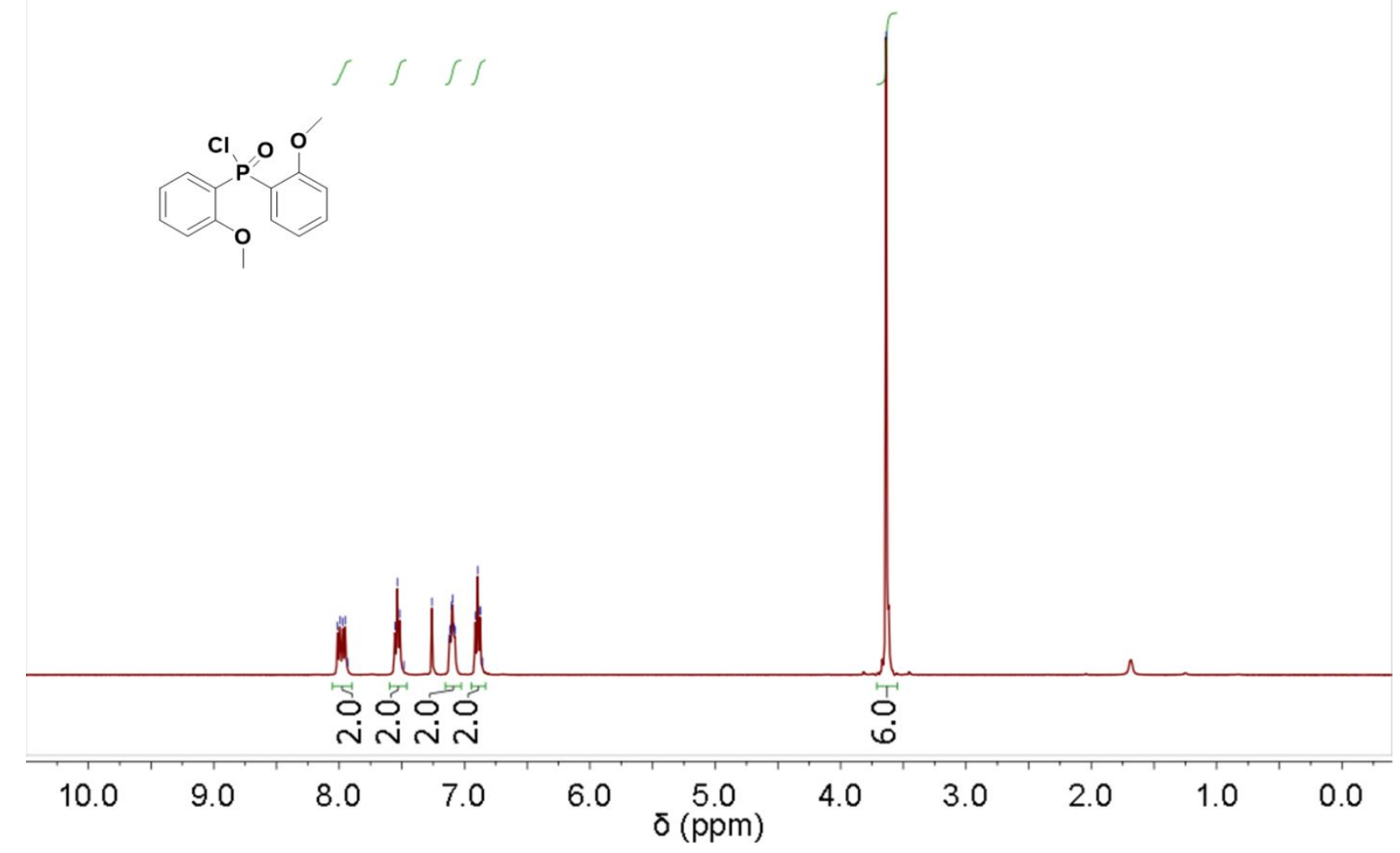

Figure S11. ${ }^{1} \mathrm{H} \mathrm{NMR}$ spectrum $\left(\mathrm{CDCl}_{3}, 400 \mathrm{MHz}\right)$ of $\mathbf{4 a}$. 


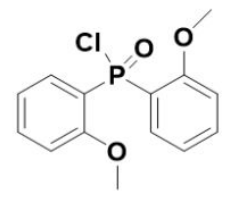

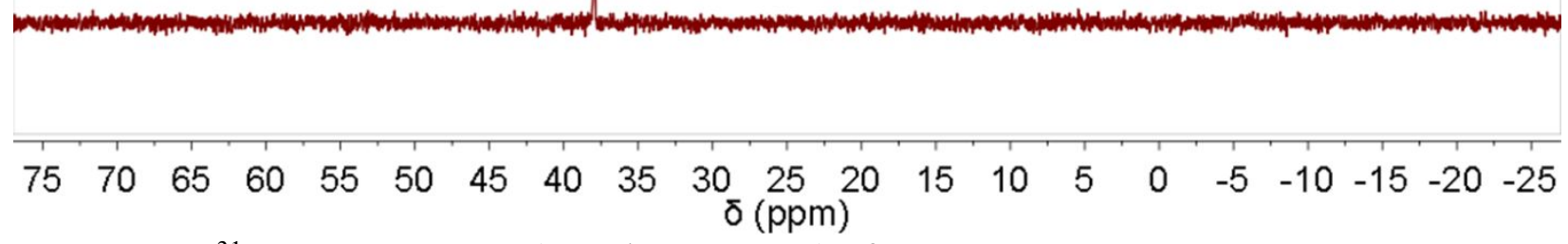

Figure S12. ${ }^{31} \mathrm{P}$ NMR spectrum $\left(\mathrm{CDCl}_{3}, 162 \mathrm{MHz}\right)$ of $4 \mathbf{a}$. 


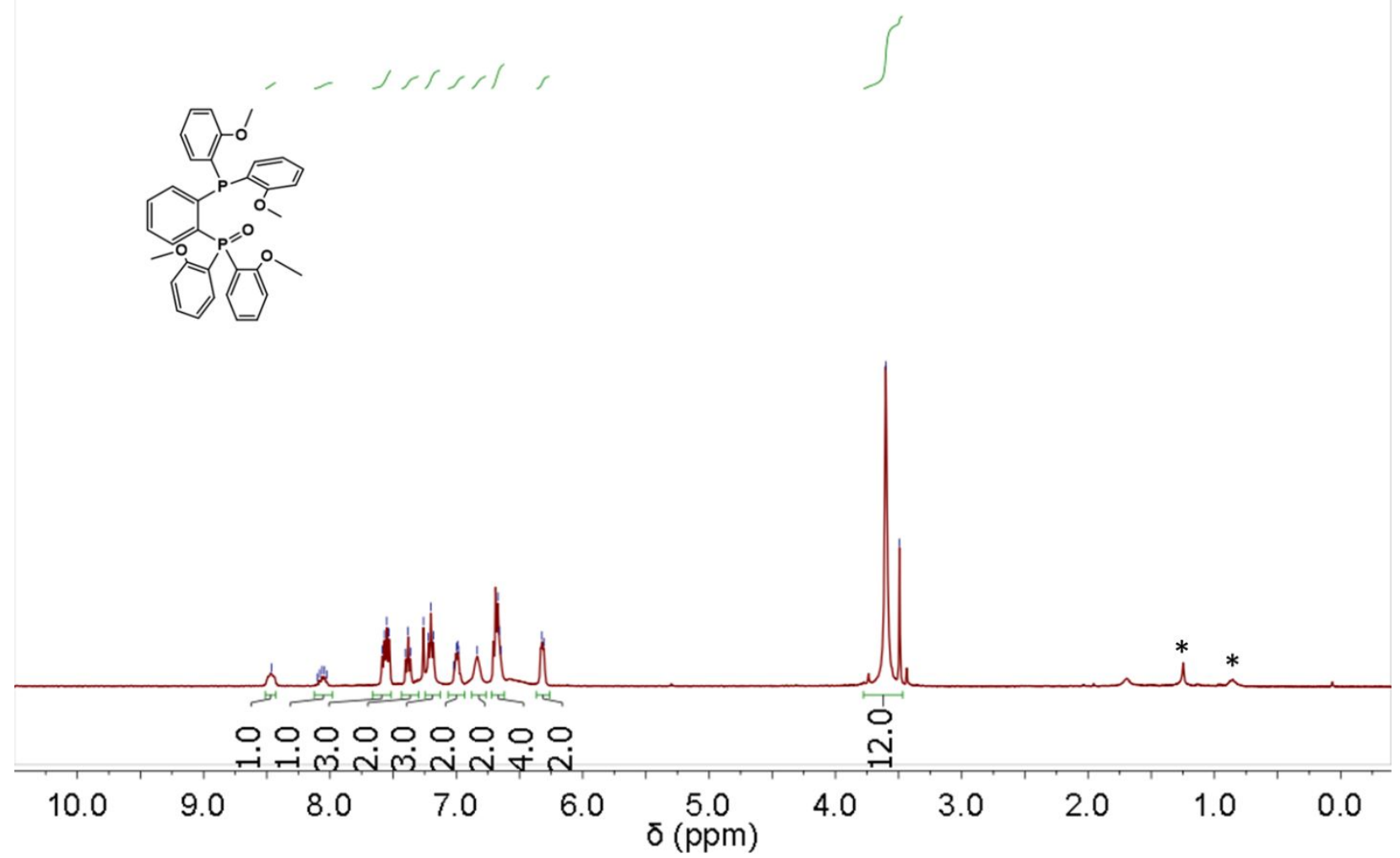

Figure S13. ${ }^{1} \mathrm{H}$ NMR spectrum $\left(\mathrm{CDCl}_{3}, 400 \mathrm{MHz}\right)$ of 6a. Impurities are marked with asterisks $(*)$. 


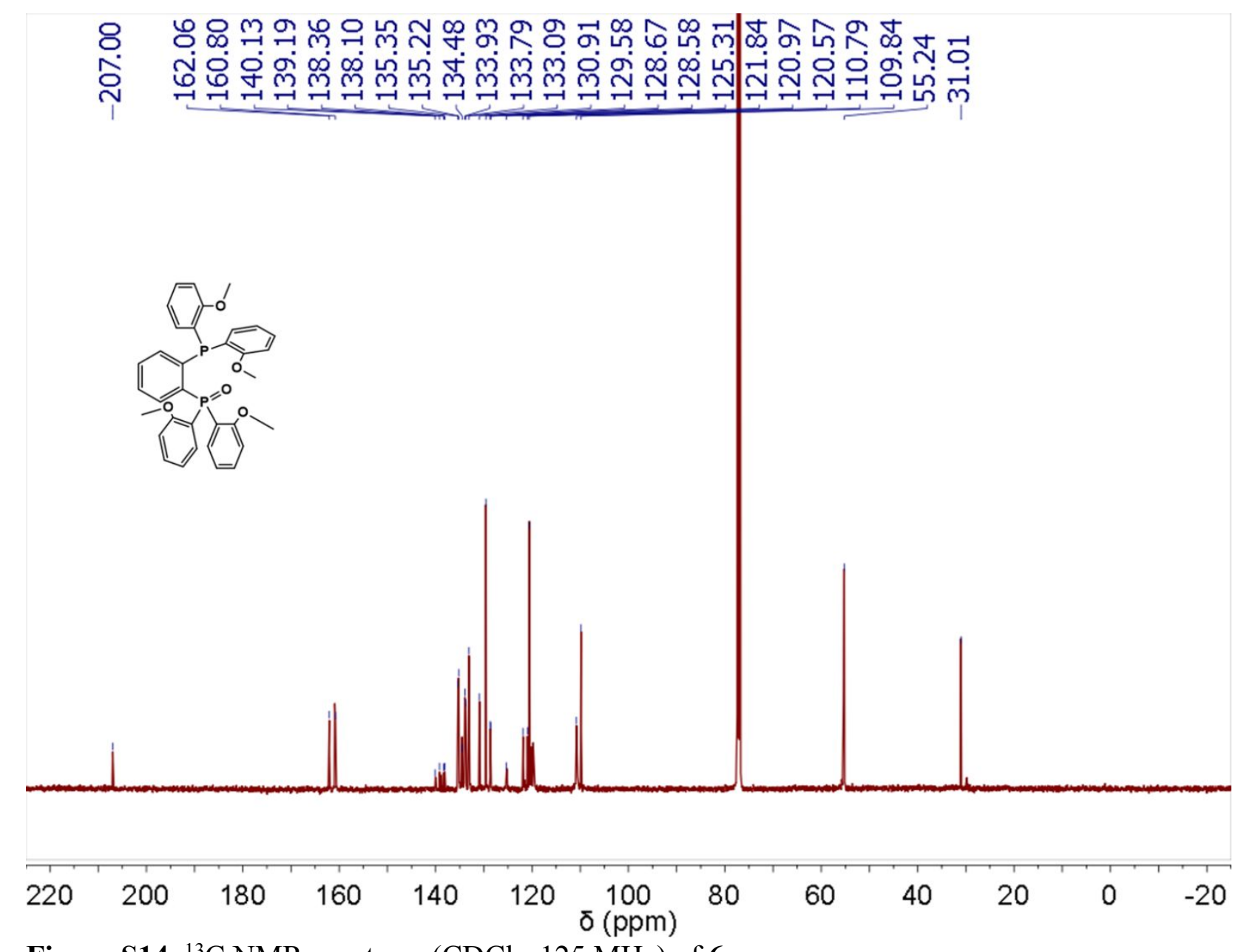

Figure S14. ${ }^{13} \mathrm{C}$ NMR spectrum $\left(\mathrm{CDCl}_{3}, 125 \mathrm{MHz}\right)$ of $\mathbf{6 a}$. 


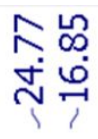
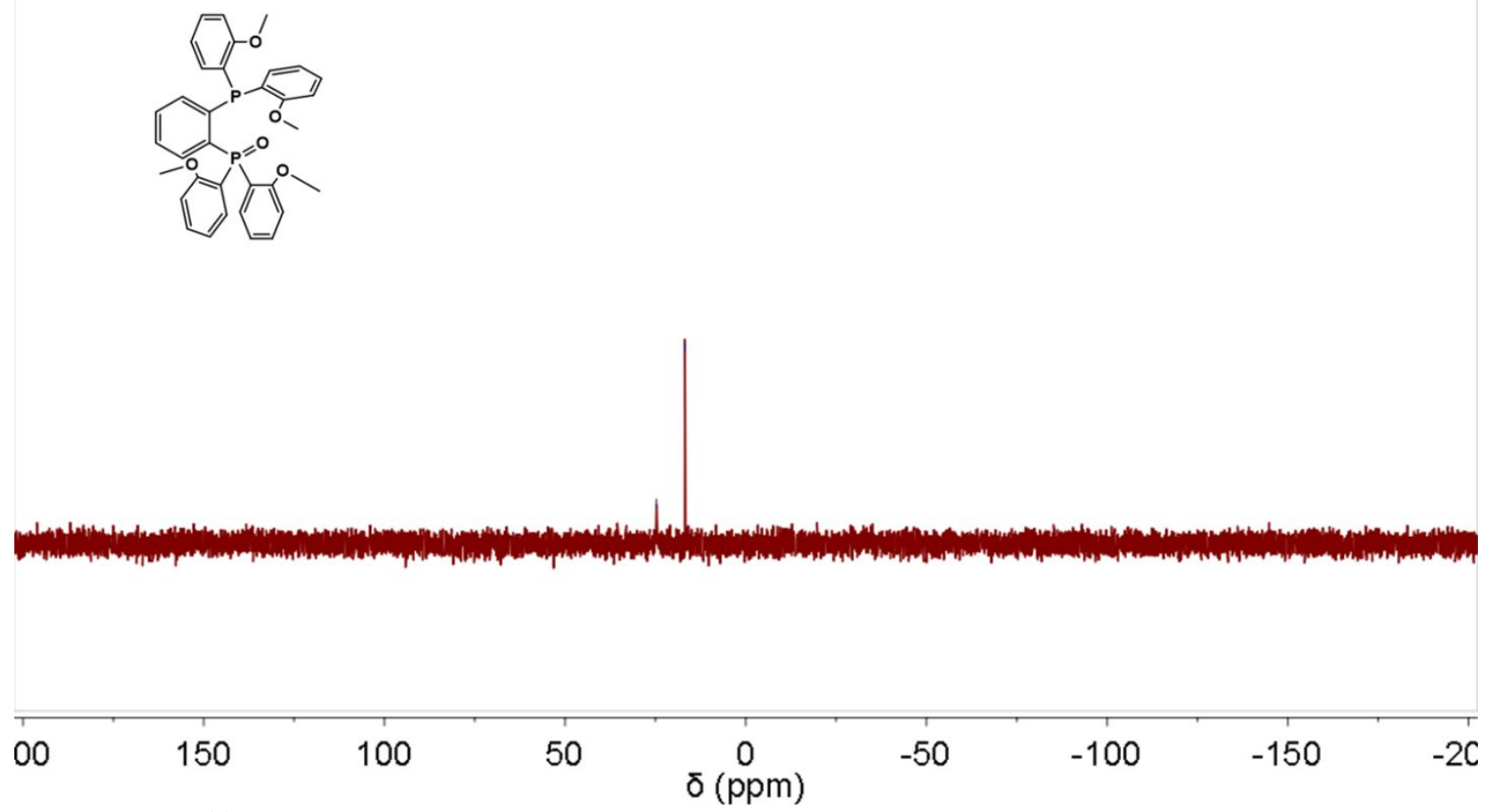

Figure S15. ${ }^{31} \mathrm{P}$ NMR spectrum $\left(\mathrm{CDCl}_{3}, 162 \mathrm{MHz}\right)$ of $\mathbf{6 a}$. 


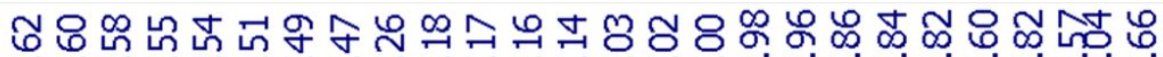

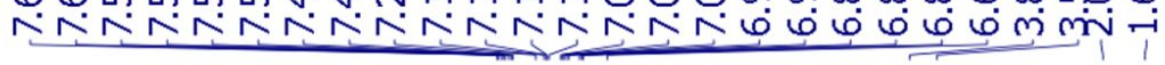
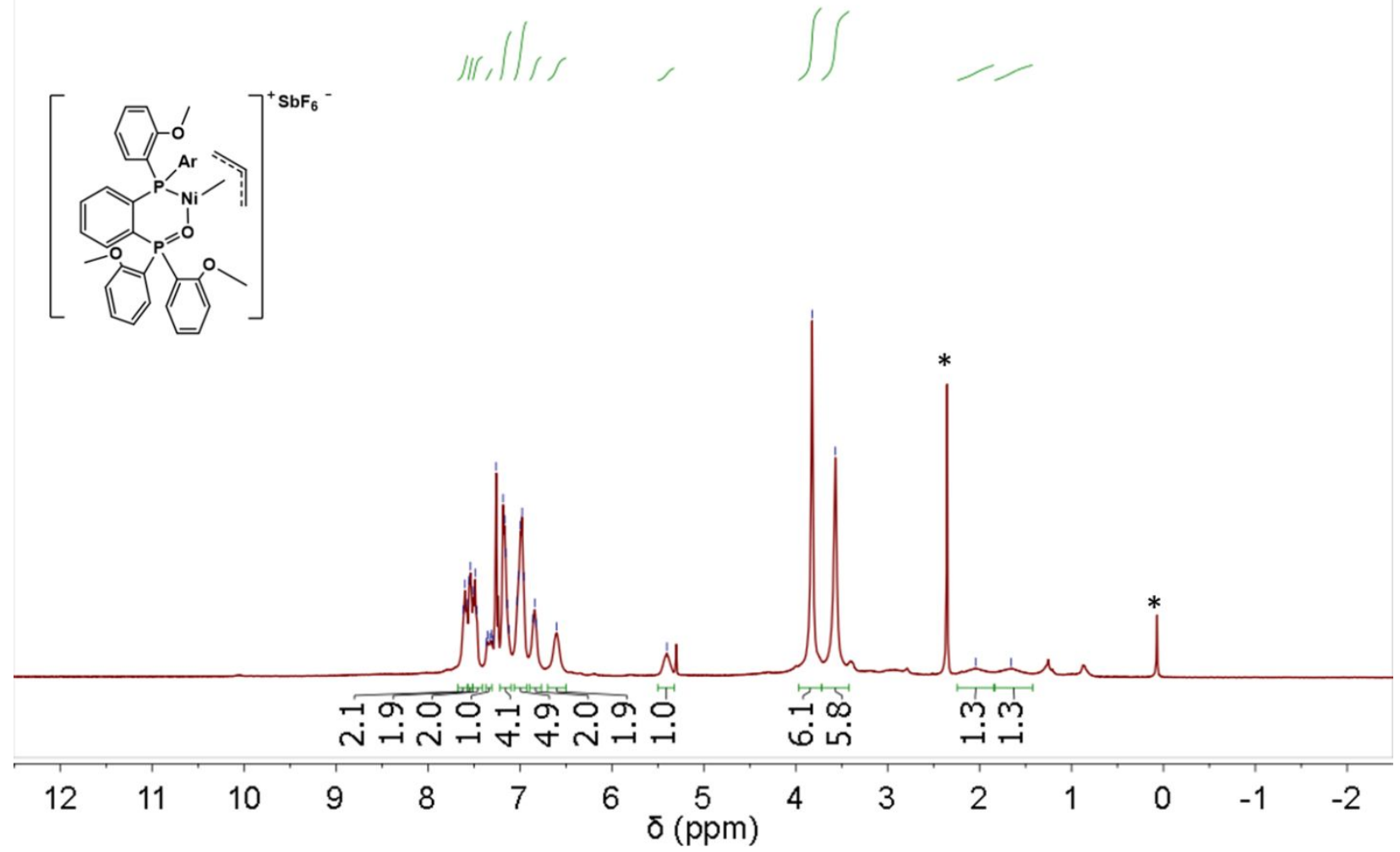

Figure S16. ${ }^{1} \mathrm{H}$ NMR spectrum $\left(\mathrm{CDCl}_{3}, 400 \mathrm{MHz}\right)$ of Ni2. Impurities are marked with asterisks $(*)$. 


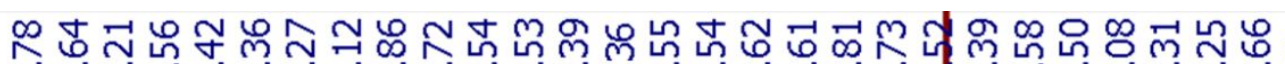

政

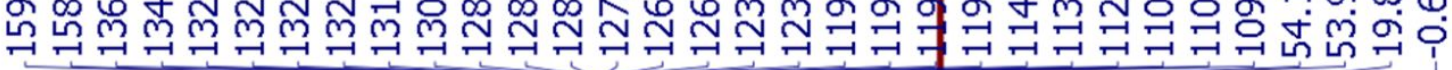
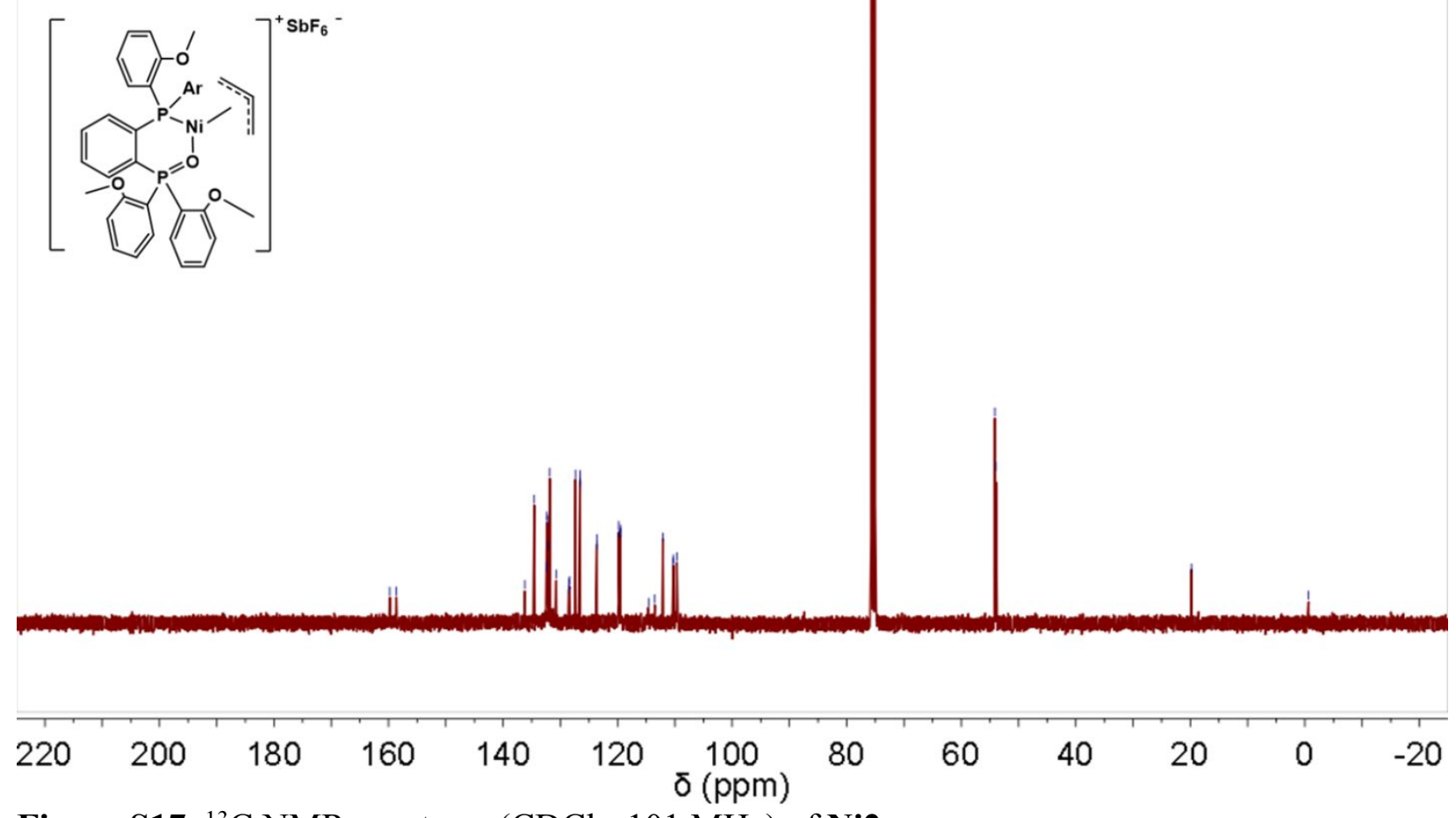

Figure S17. ${ }^{13} \mathrm{C}$ NMR spectrum $\left(\mathrm{CDCl}_{3}, 101 \mathrm{MHz}\right)$ of $\mathbf{N i 2}$. 
ڤิ
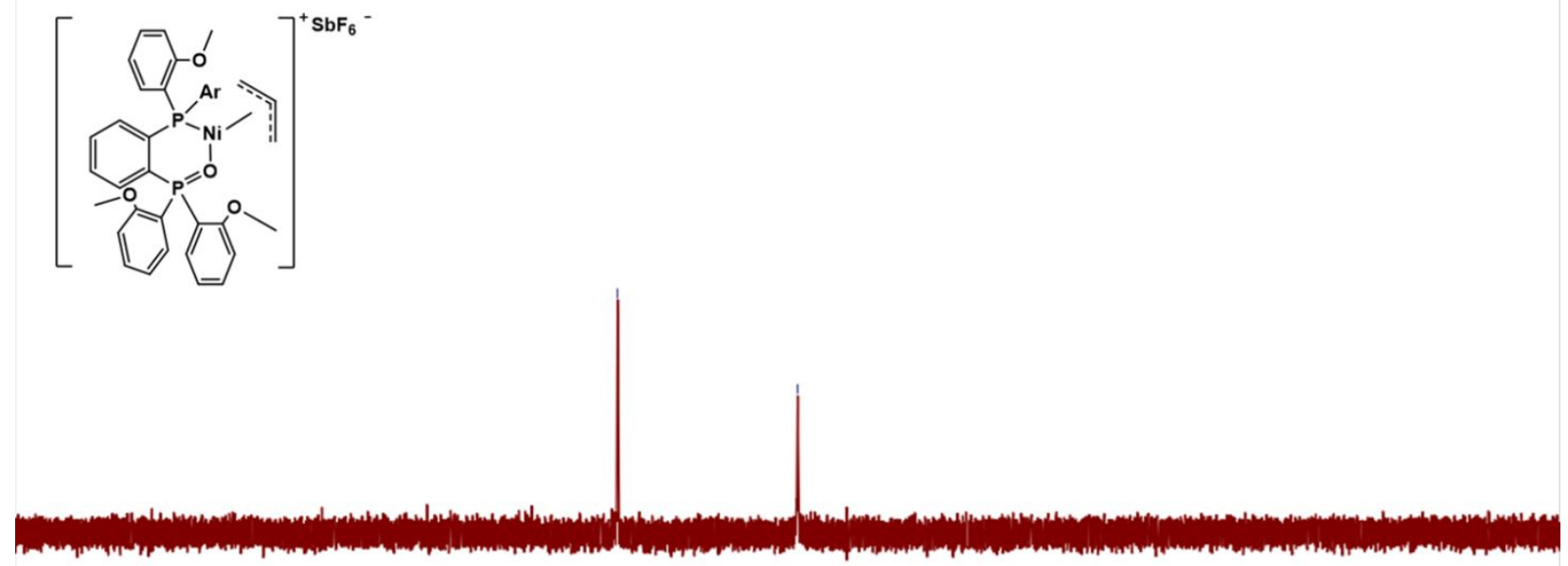

\begin{tabular}{|c|c|c|c|c|c|c|c|}
\hline 50 & 150 & 100 & 50 & $\begin{array}{c}0 \\
\delta(\mathrm{ppm})\end{array}$ & -50 & -100 & -150 \\
\hline
\end{tabular}

Figure S18. ${ }^{31} \mathrm{P}$ NMR spectrum $\left(\mathrm{CDCl}_{3}, 202 \mathrm{MHz}\right)$ of $\mathbf{N i 2}$. 


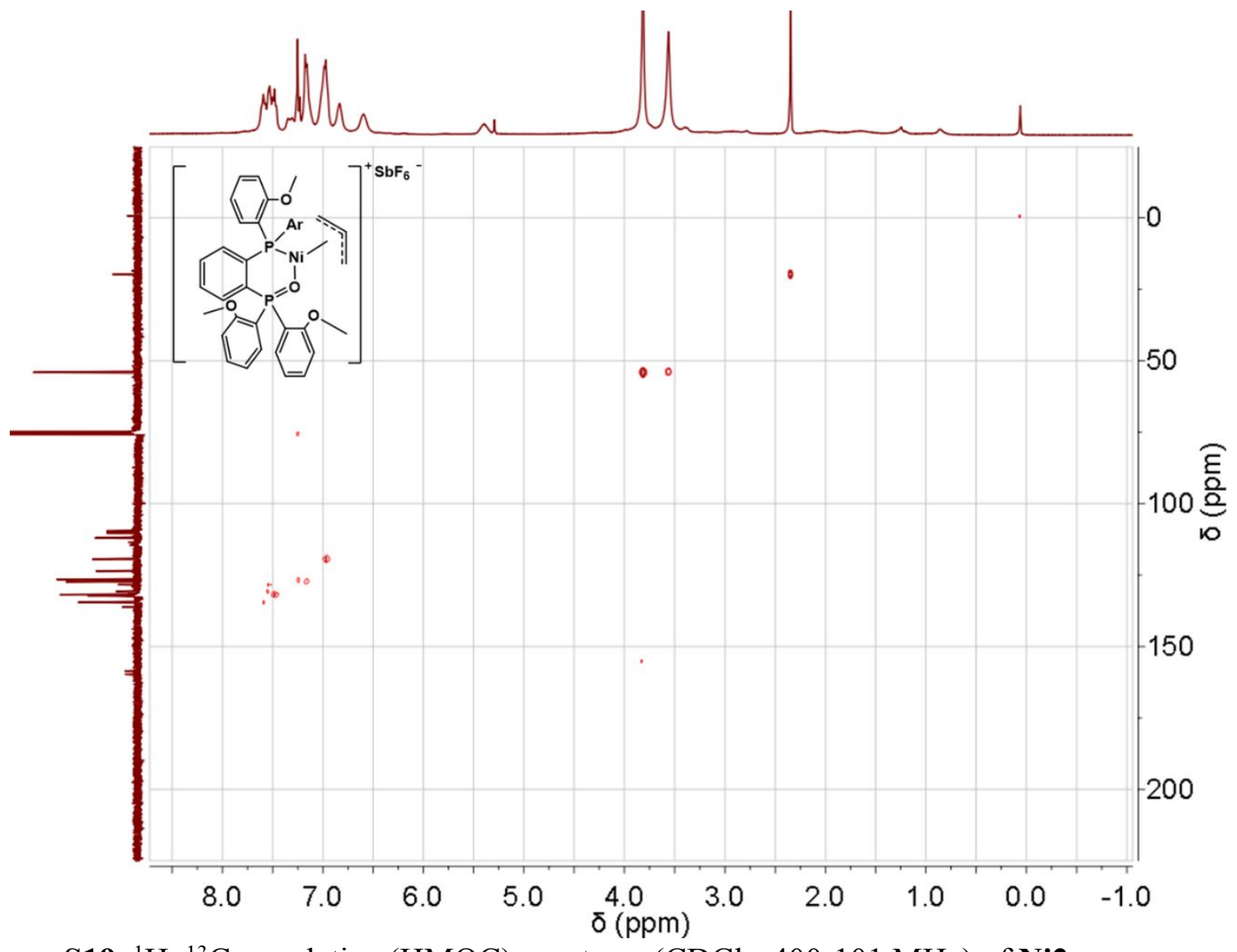

Figure S19. ${ }^{1} \mathrm{H}-{ }^{13} \mathrm{C}$ correlation (HMQC) spectrum $\left(\mathrm{CDCl}_{3}, 400-101 \mathrm{MHz}\right)$ of $\mathbf{N i 2}$. 


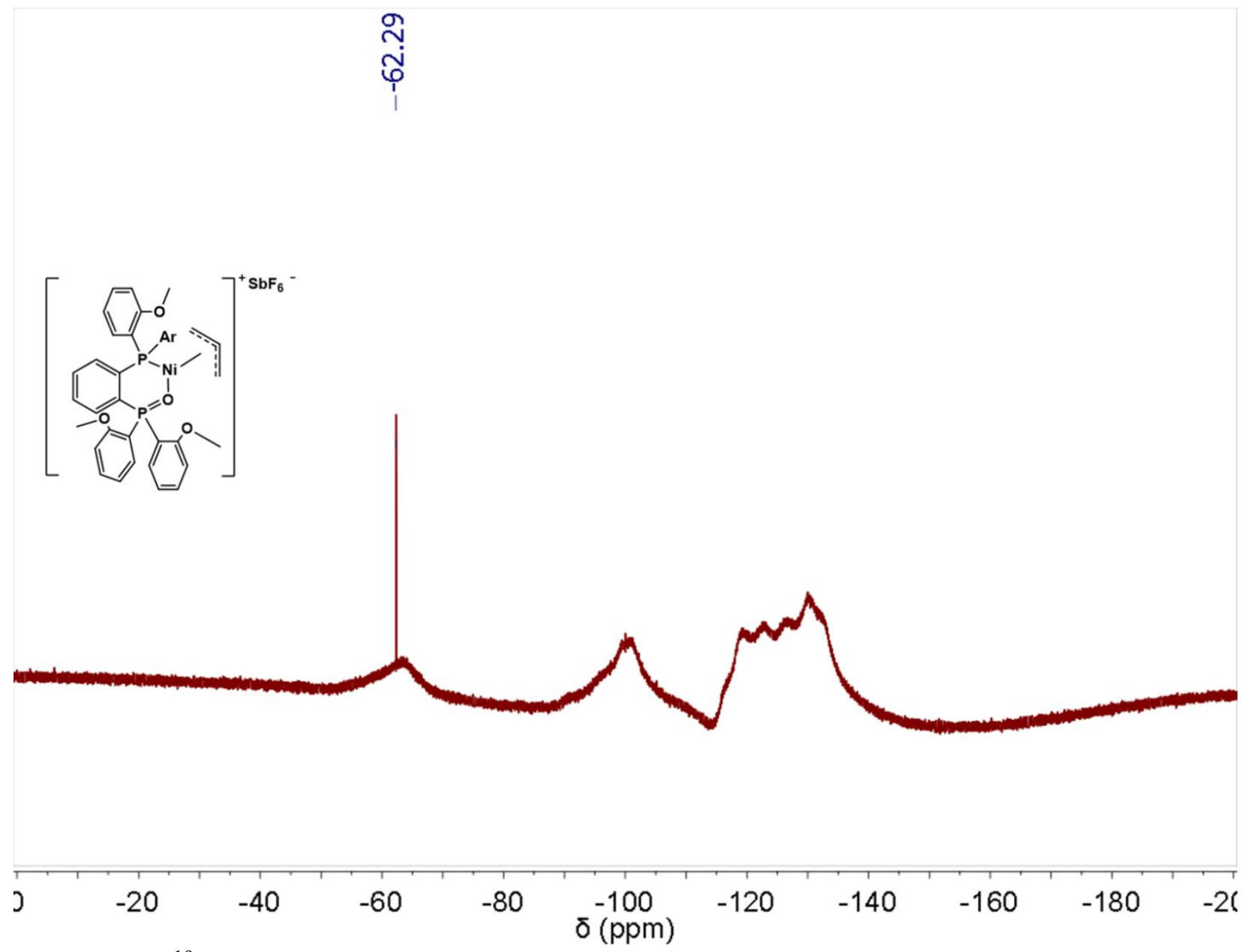

Figure S20. ${ }^{19} \mathrm{~F}$ NMR spectrum $\left(\mathrm{CDCl}_{3}, 470 \mathrm{MHz}\right)$ of $\mathrm{Ni2}$. The reason for the broad peaks is unclear; we hypothesize it may be due to reversible association of $\mathrm{SbF}_{6}{ }^{-}$with the nickel center. 


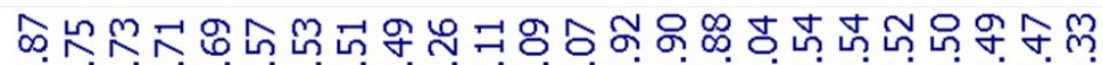

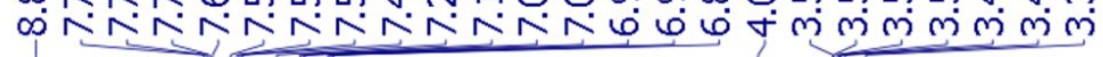

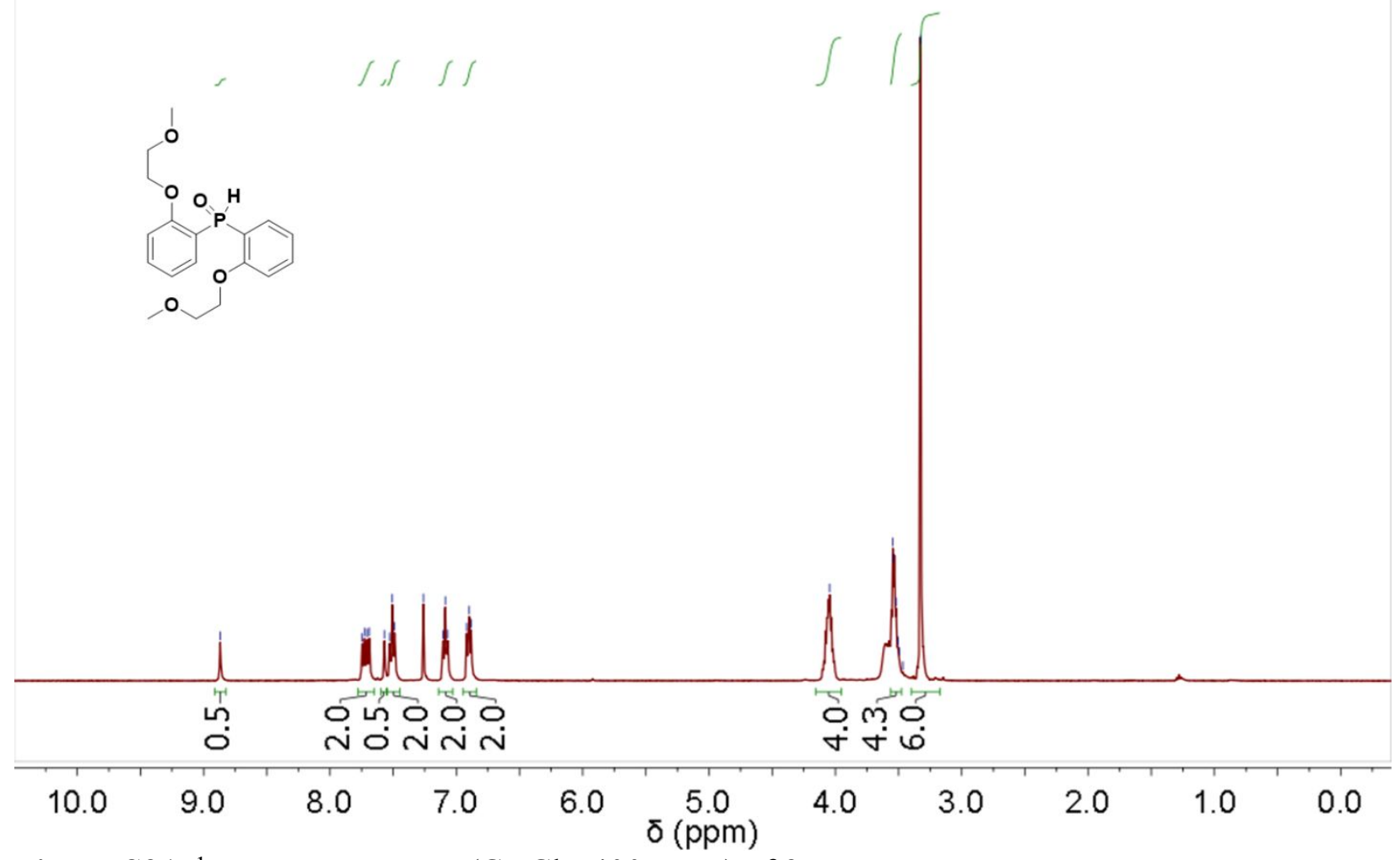

Figure S21. ${ }^{1} \mathrm{H}$ NMR spectrum $\left(\mathrm{CDCl}_{3}, 400 \mathrm{MHz}\right)$ of $\mathbf{2 b}$. 


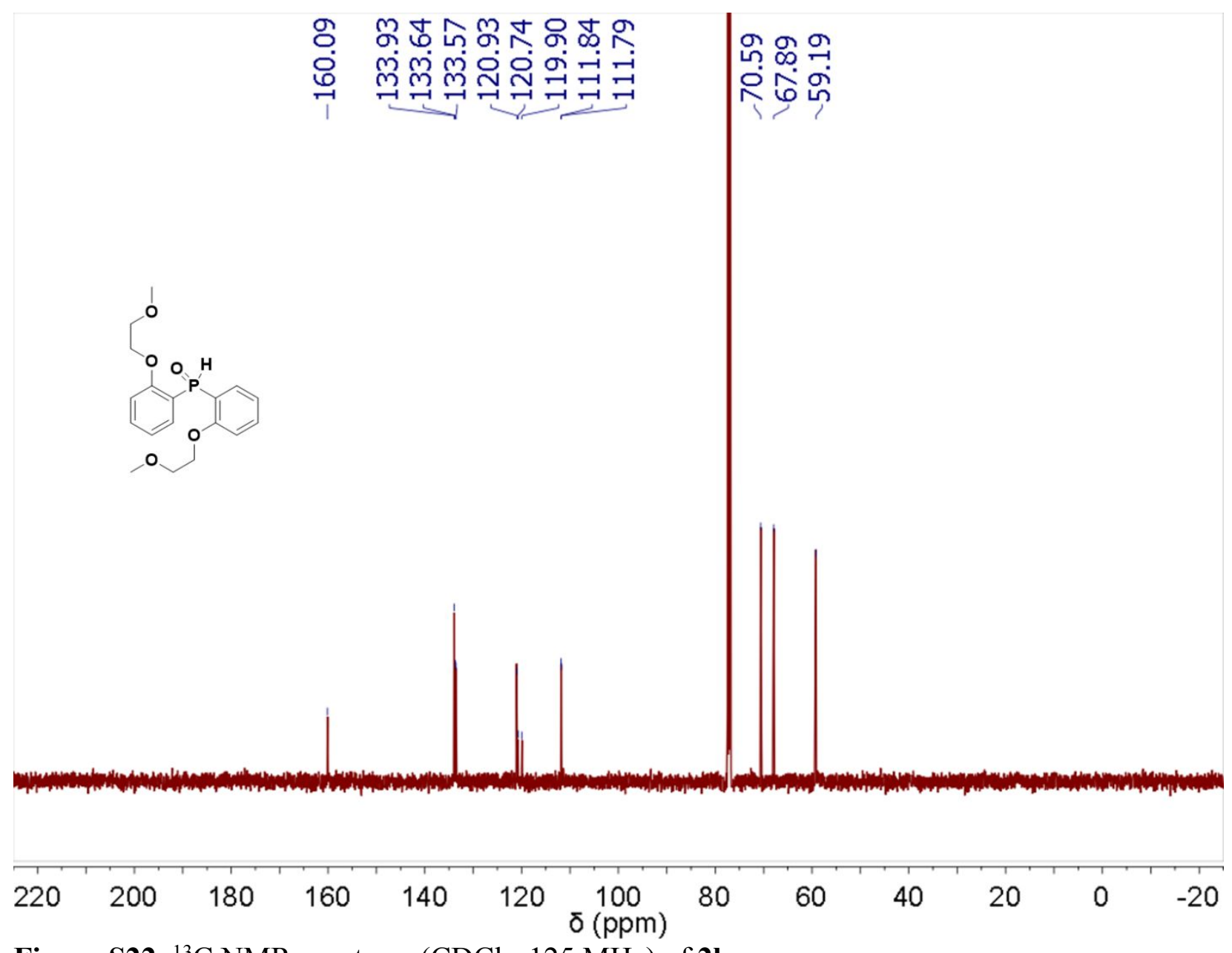

Figure S22. ${ }^{13} \mathrm{C}$ NMR spectrum $\left(\mathrm{CDCl}_{3}, 125 \mathrm{MHz}\right)$ of $\mathbf{2 b}$. 

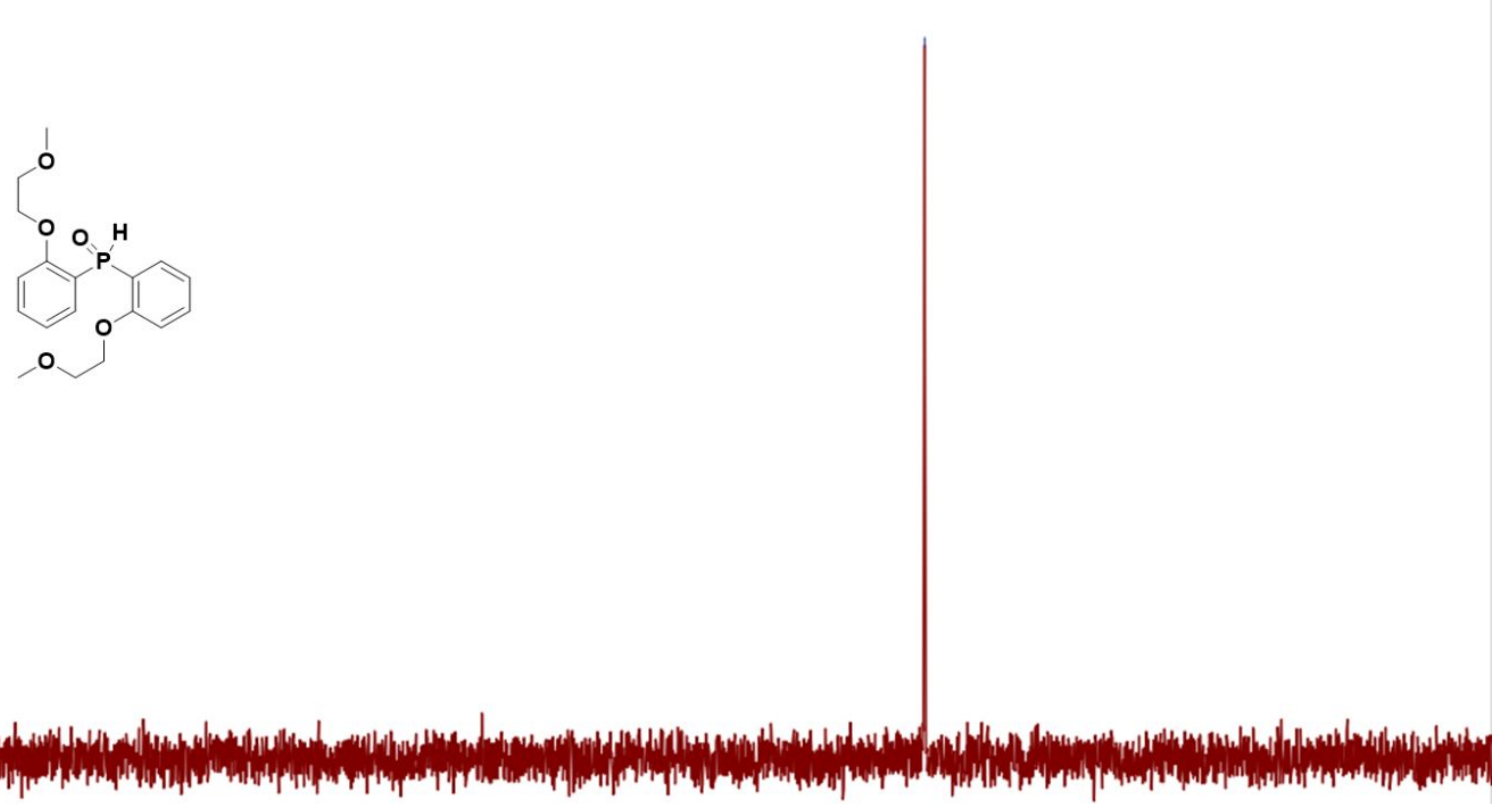

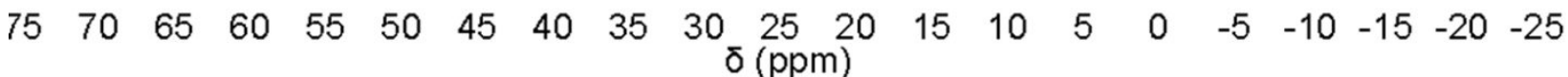

Figure S23. ${ }^{31} \mathrm{P}$ NMR spectrum $\left(\mathrm{CDCl}_{3}, 162 \mathrm{MHz}\right)$ of $\mathbf{2 b}$. 

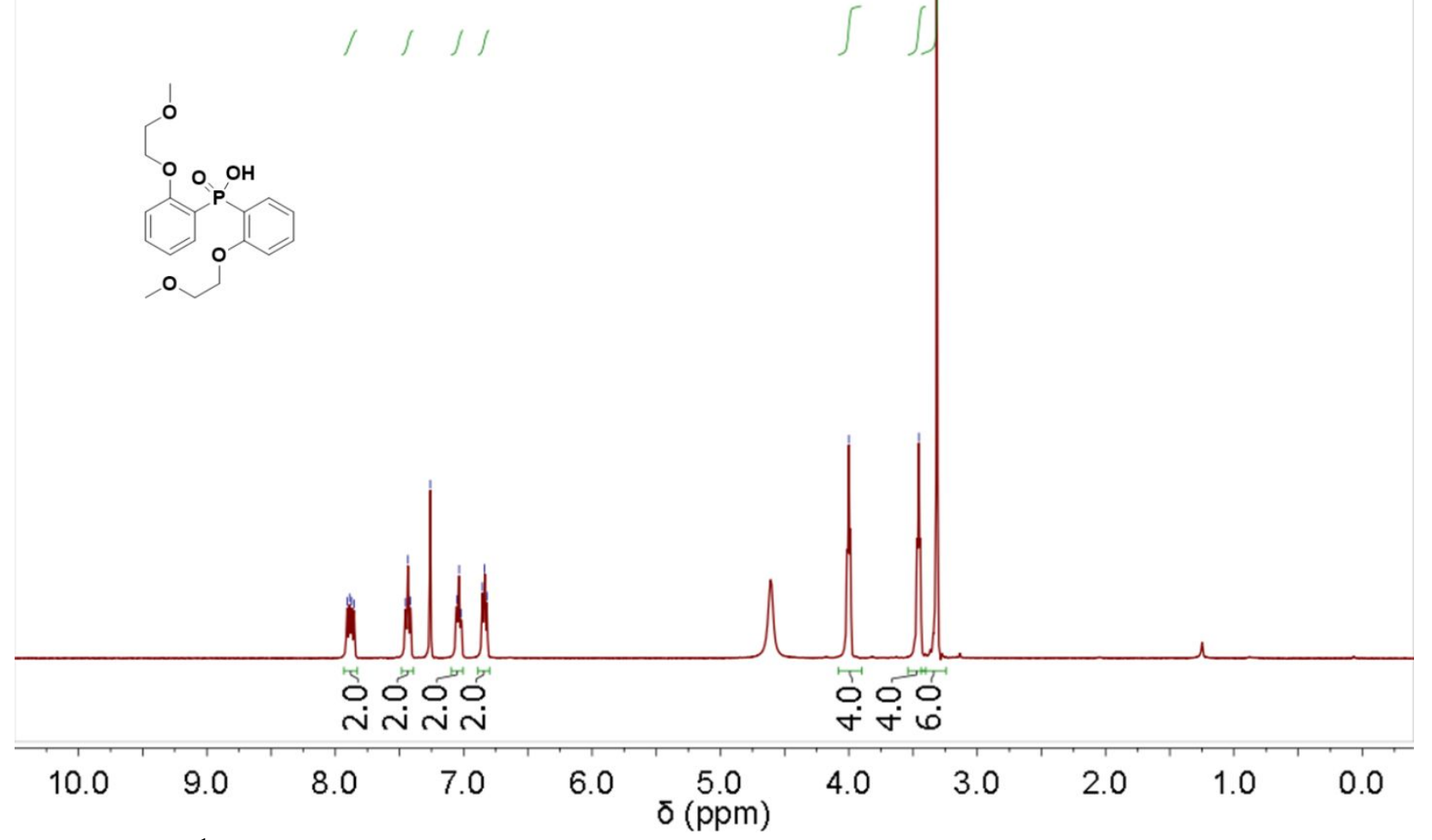

Figure S24. ${ }^{1} \mathrm{H}$ NMR spectrum $\left(\mathrm{CDCl}_{3}, 400 \mathrm{MHz}\right)$ of $\mathbf{3 b}$. 


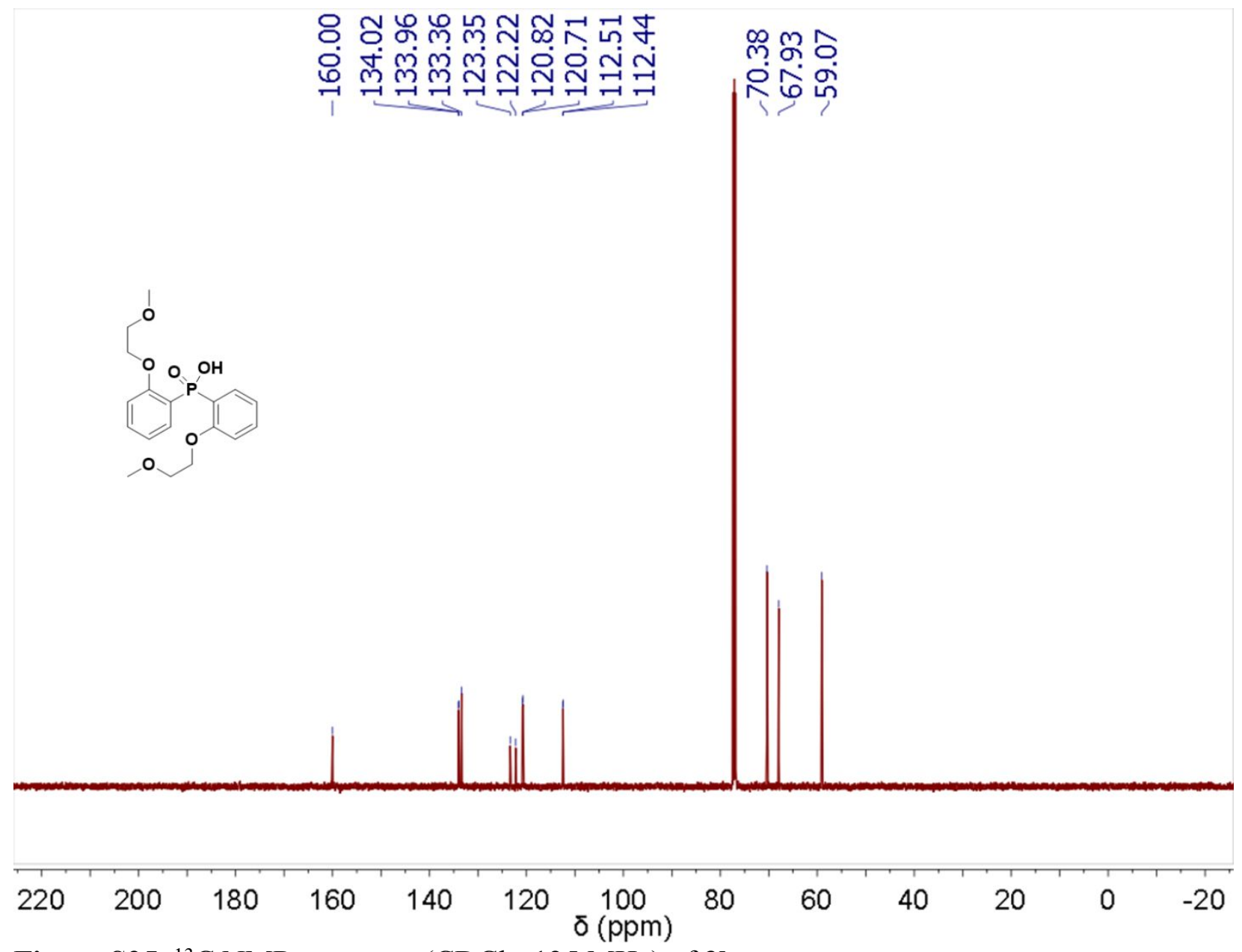

Figure S25. ${ }^{13} \mathrm{C}$ NMR spectrum $\left(\mathrm{CDCl}_{3}, 125 \mathrm{MHz}\right)$ of $\mathbf{3 b}$. 
맘

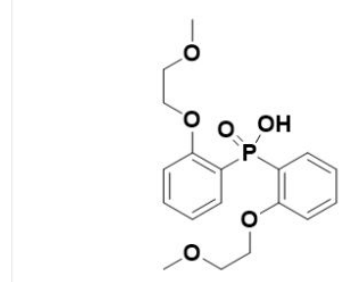

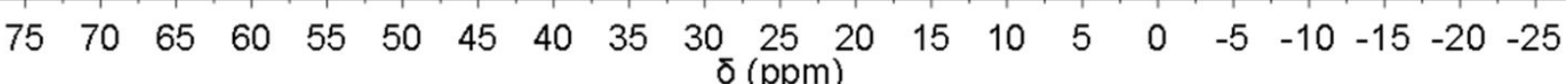

Figure S26. ${ }^{31} \mathrm{P} \mathrm{NMR}$ spectrum $\left(\mathrm{CDCl}_{3}, 202 \mathrm{MHz}\right)$ of $\mathbf{3 b}$. 


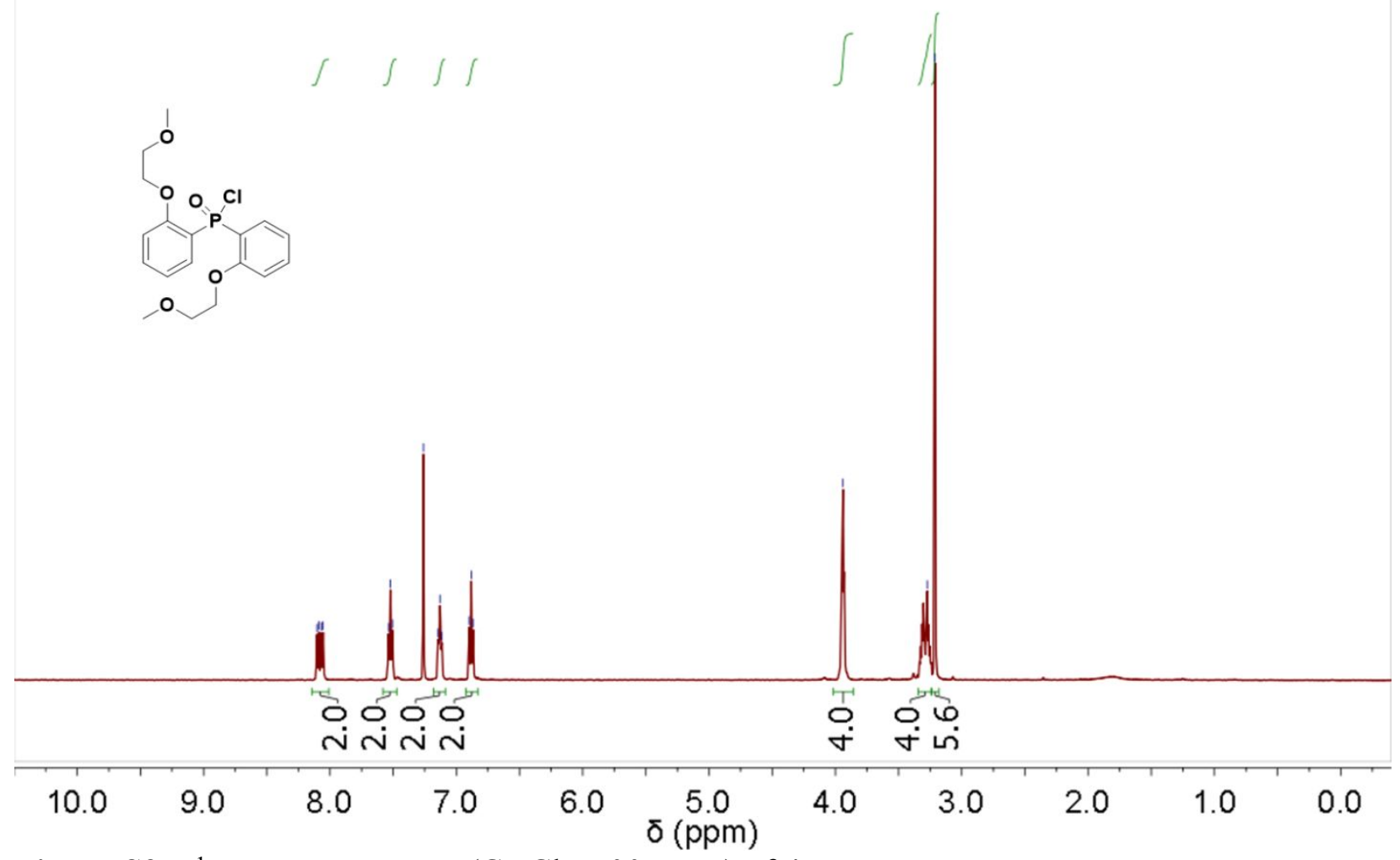

Figure S27. ${ }^{1} \mathrm{H}$ NMR spectrum $\left(\mathrm{CDCl}_{3}, 500 \mathrm{MHz}\right)$ of $\mathbf{4 b}$. 


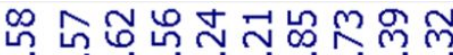

怂

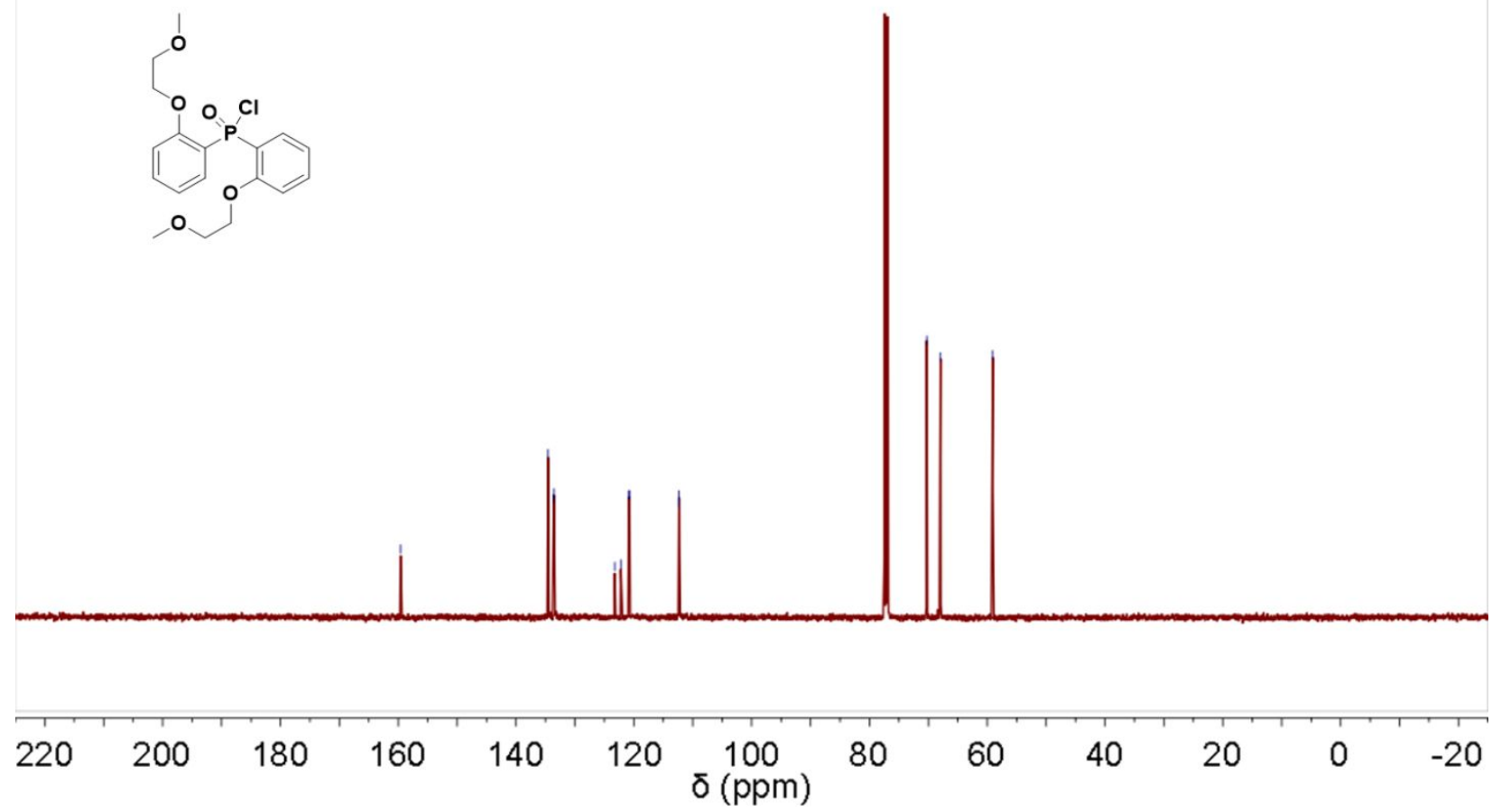

Figure S28. ${ }^{13} \mathrm{C}$ NMR spectrum $\left(\mathrm{CDCl}_{3}, 125 \mathrm{MHz}\right)$ of $\mathbf{4 b}$. 
חָ
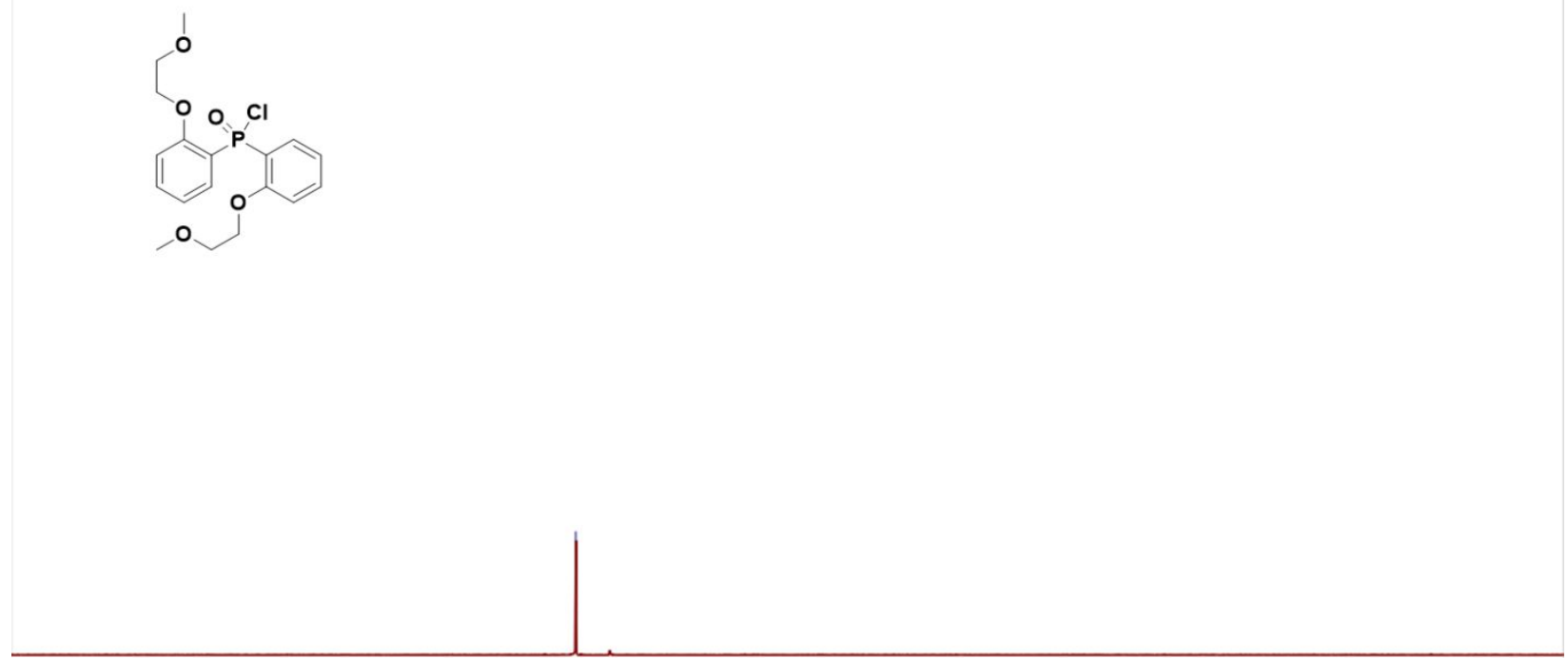

$\begin{array}{lllllllllllllllllllllllllllllll}75 & 70 & 65 & 60 & 55 & 50 & 45 & 40 & 35 & 30 & 25 & 20 & 15 & 10 & 5 & 0 & -5 & -10 & -15 & -20 & -25\end{array}$

Figure S29. ${ }^{31} \mathrm{P} \mathrm{NMR}$ spectrum $\left(\mathrm{CDCl}_{3}, 202 \mathrm{MHz}\right)$ of $\mathbf{4 b}$. 


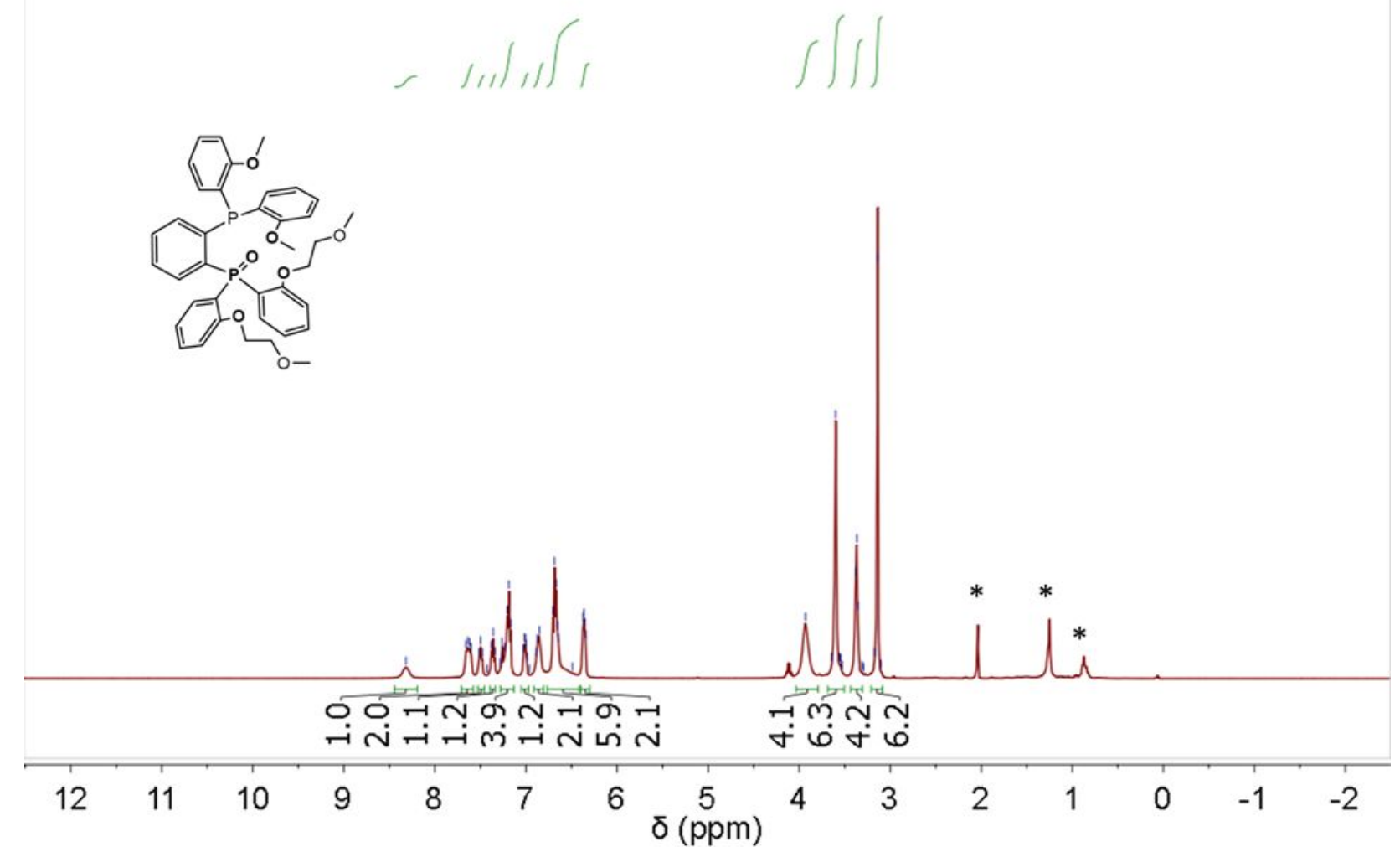

Figure S30. ${ }^{1} \mathrm{H}$ NMR spectrum $\left(\mathrm{CDCl}_{3}, 400 \mathrm{MHz}\right)$ of $\mathbf{6 b}$. Impurities are marked with an asterisk $\left(^{*}\right)$. 


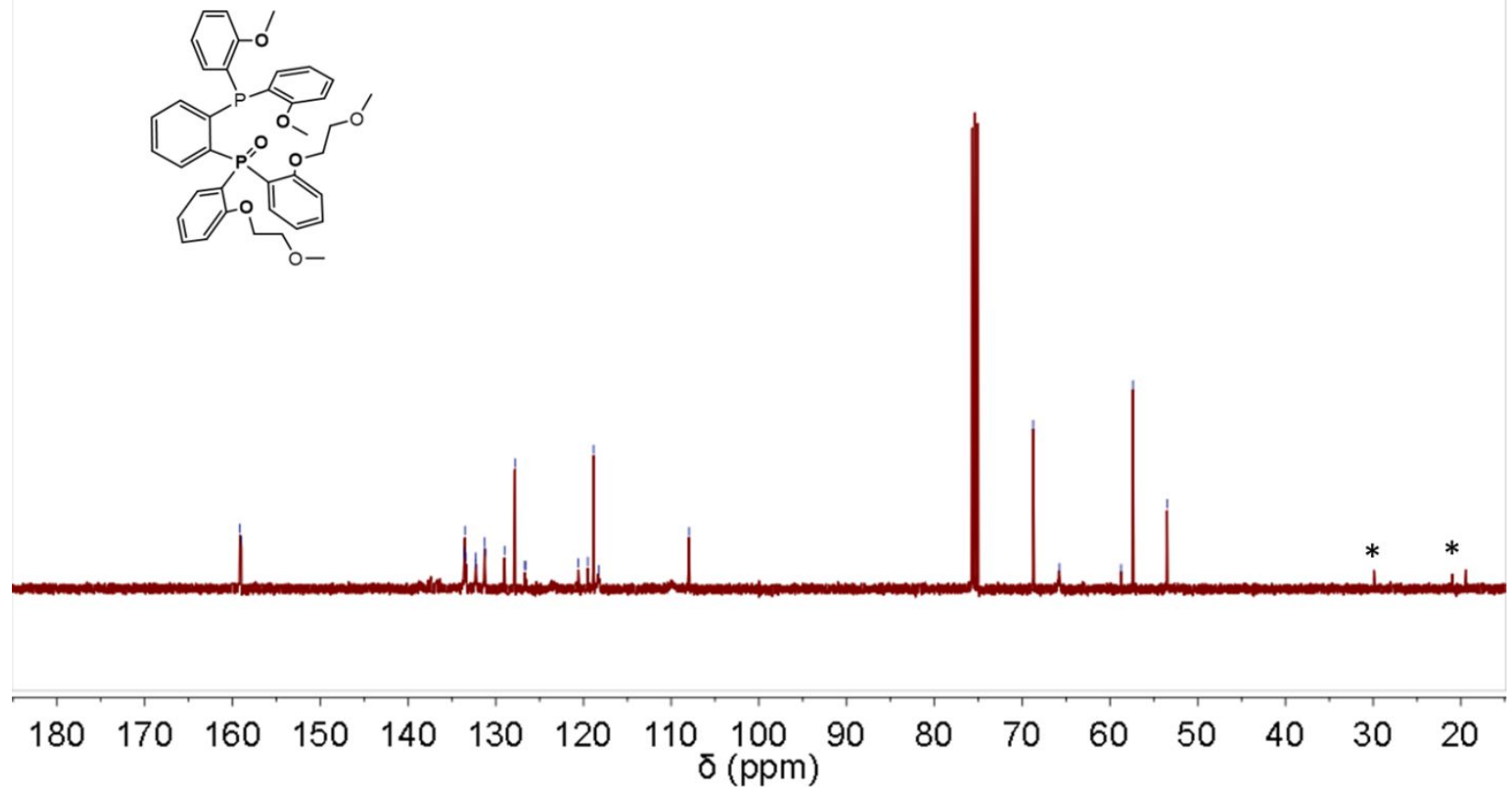

Figure S31. ${ }^{13} \mathrm{C}$ NMR spectrum $\left(\mathrm{CDCl}_{3}, 101 \mathrm{MHz}\right)$ of $\mathbf{6 b}$. Trace solvent peaks are marked with asterisks $(*)$. 


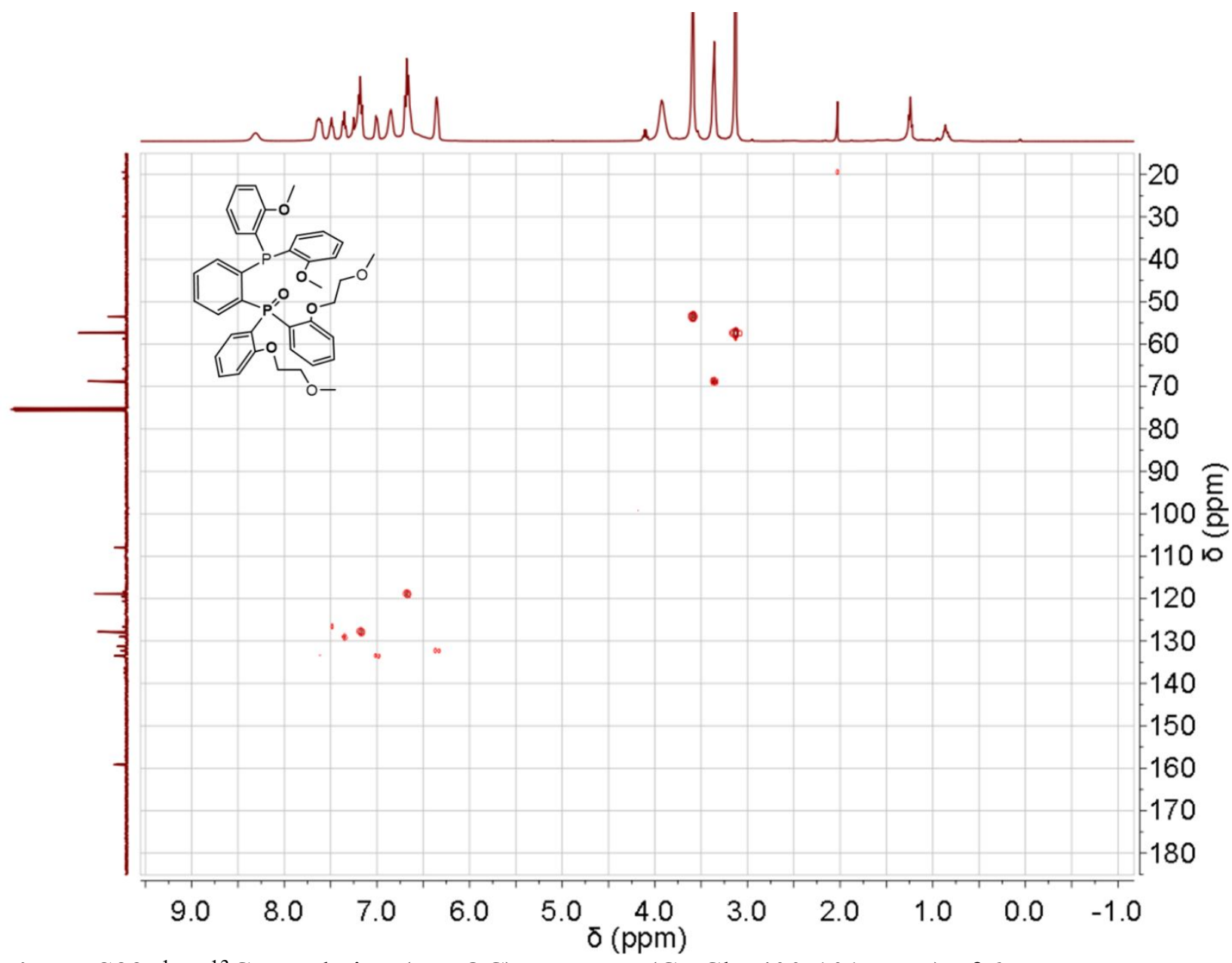

Figure S32. ${ }^{1} \mathrm{H}-{ }^{13} \mathrm{C}$ correlation (HMQC) spectrum $\left(\mathrm{CDCl}_{3}, 400-101 \mathrm{MHz}\right)$ of $6 \mathbf{b}$. 

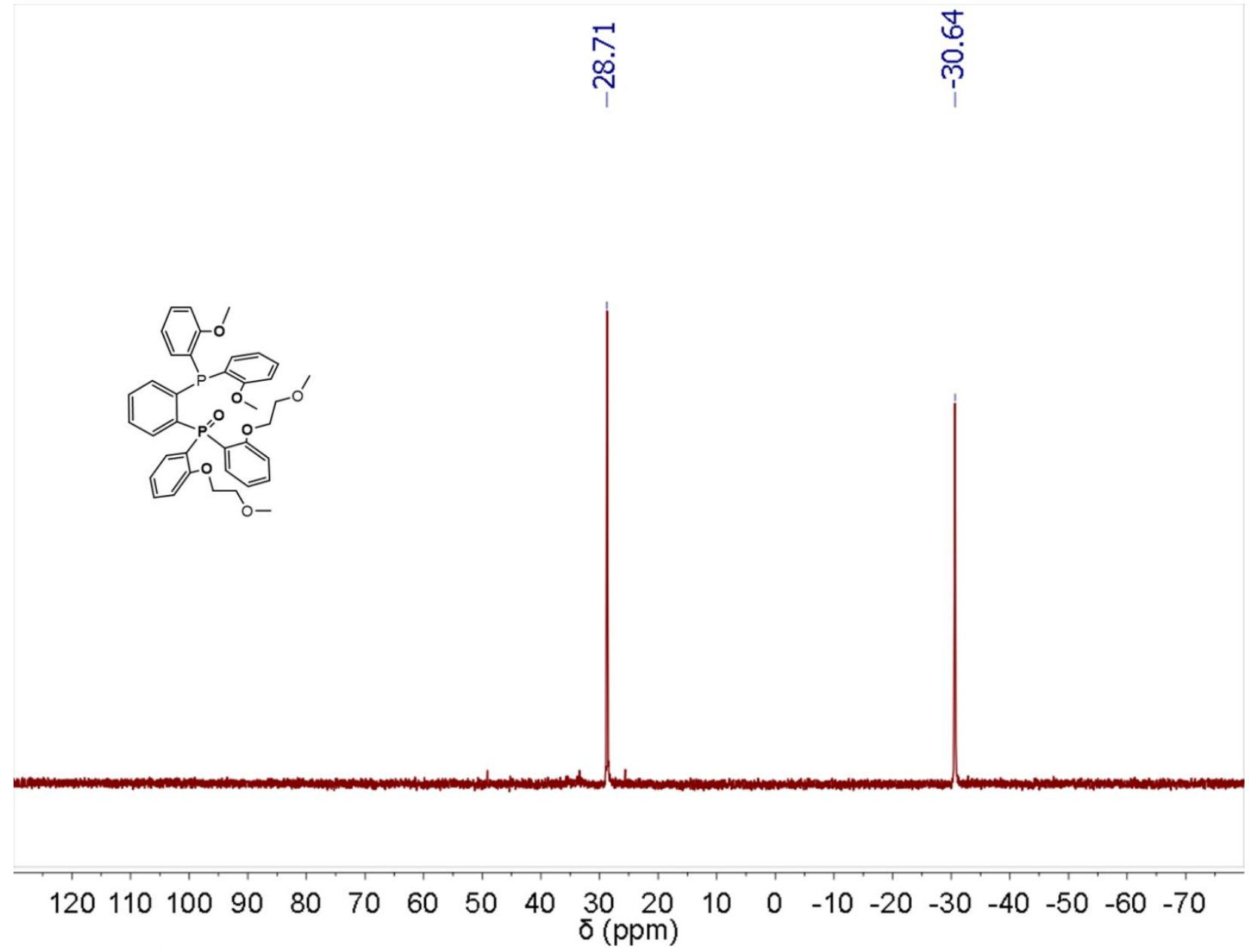

Figure 33. ${ }^{31} \mathrm{P} \mathrm{NMR}$ spectrum $\left(\mathrm{CDCl}_{3}, 243 \mathrm{MHz}\right)$ of $\mathbf{6 b}$. 


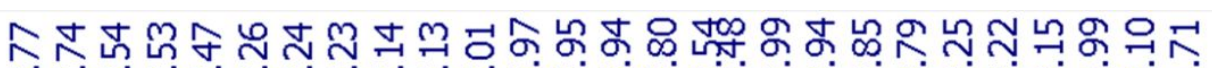

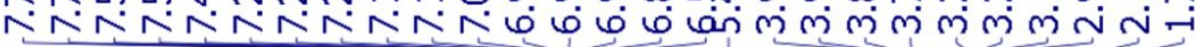
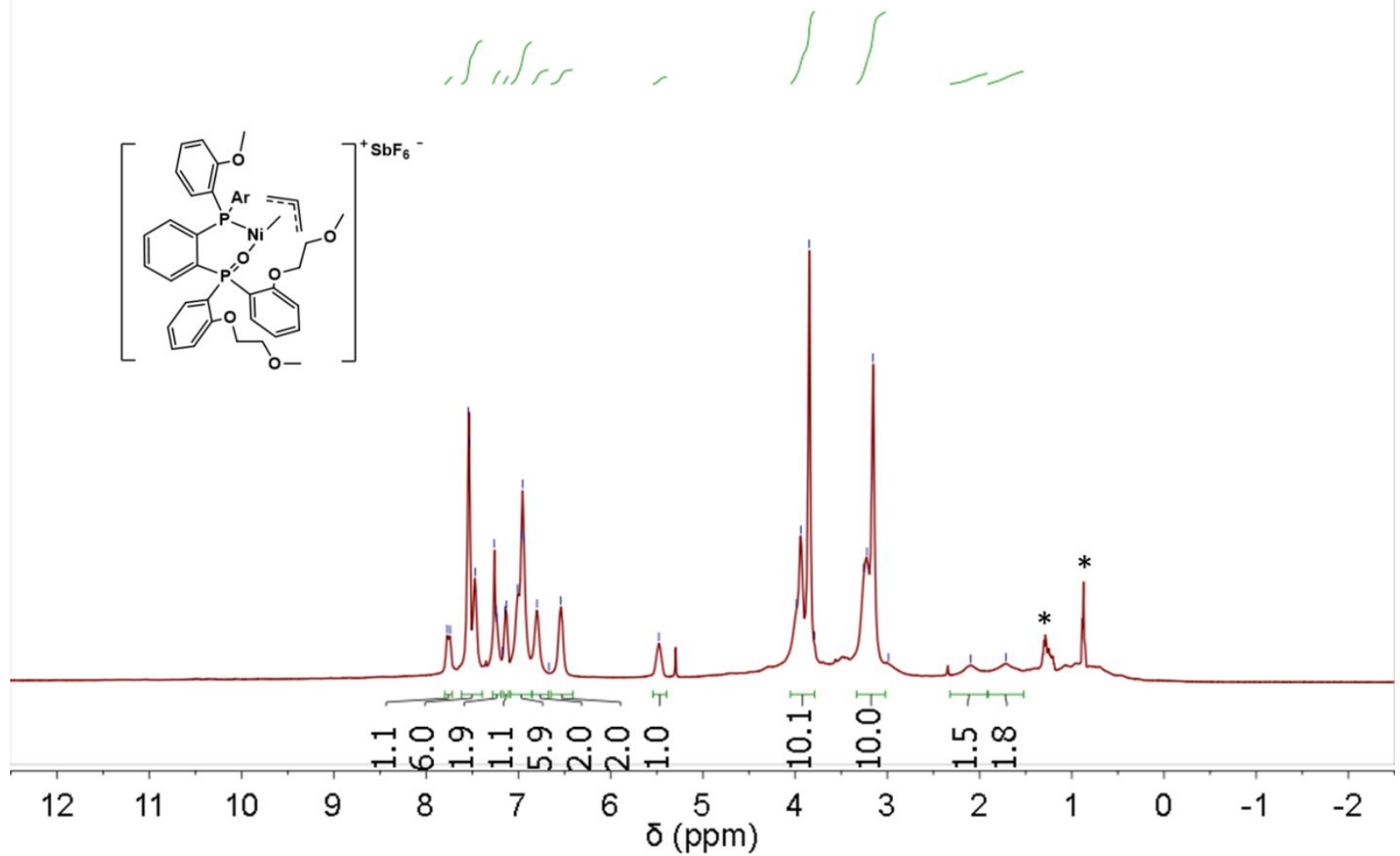

Figure S34. ${ }^{1} \mathrm{H}$ NMR spectrum $\left(\mathrm{CDCl}_{3}, 500 \mathrm{MHz}\right)$ of Ni3. Impurities peaks marked with asterisks $(*)$. 


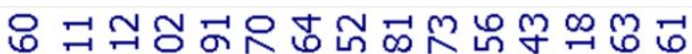

め ن்

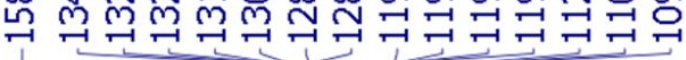

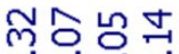

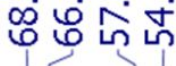
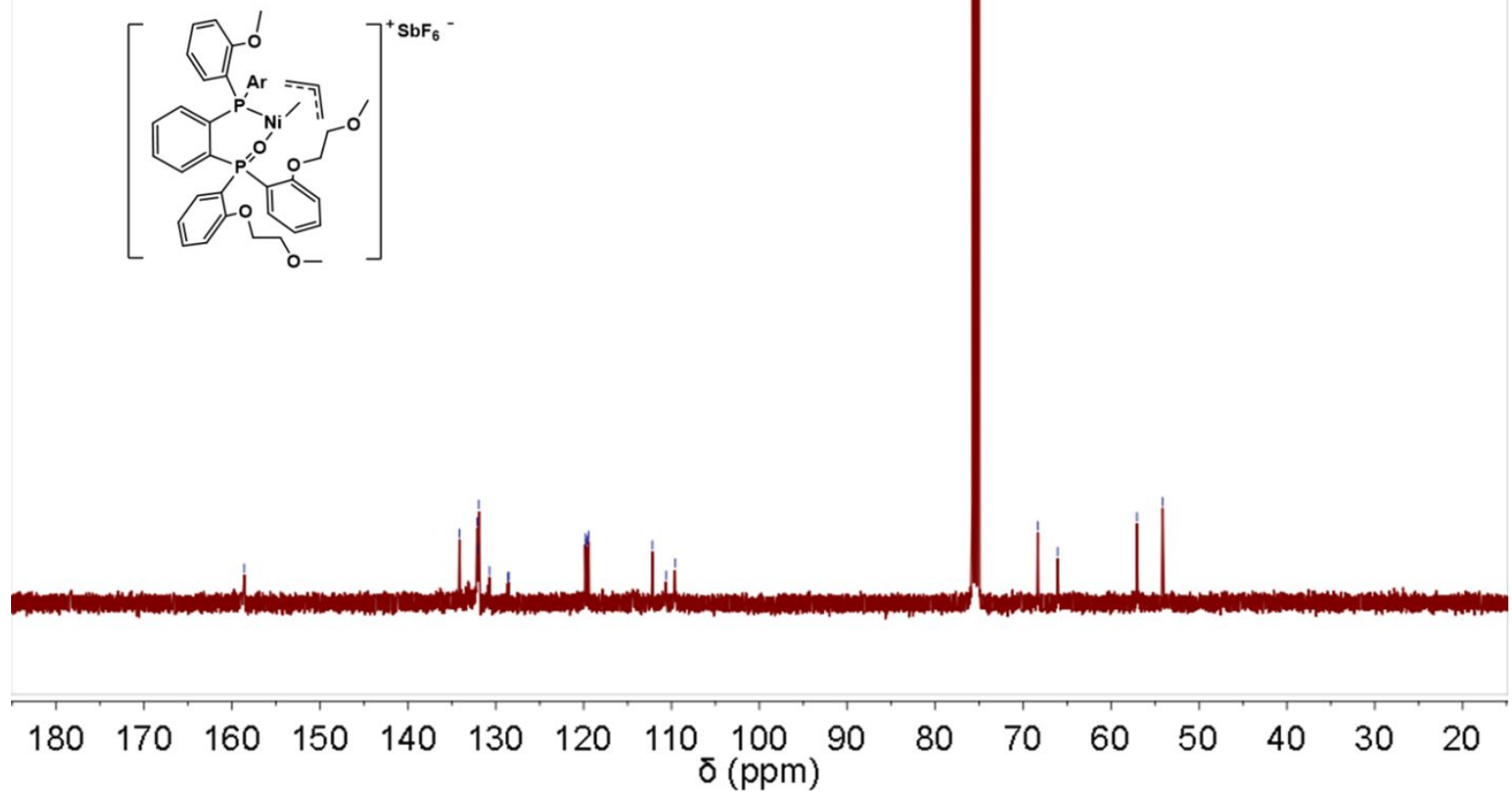

Figure S35. ${ }^{13} \mathrm{C}$ NMR spectrum $\left(\mathrm{CDCl}_{3}, 101 \mathrm{MHz}\right)$ of $\mathbf{N i 3}$. 


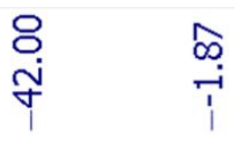
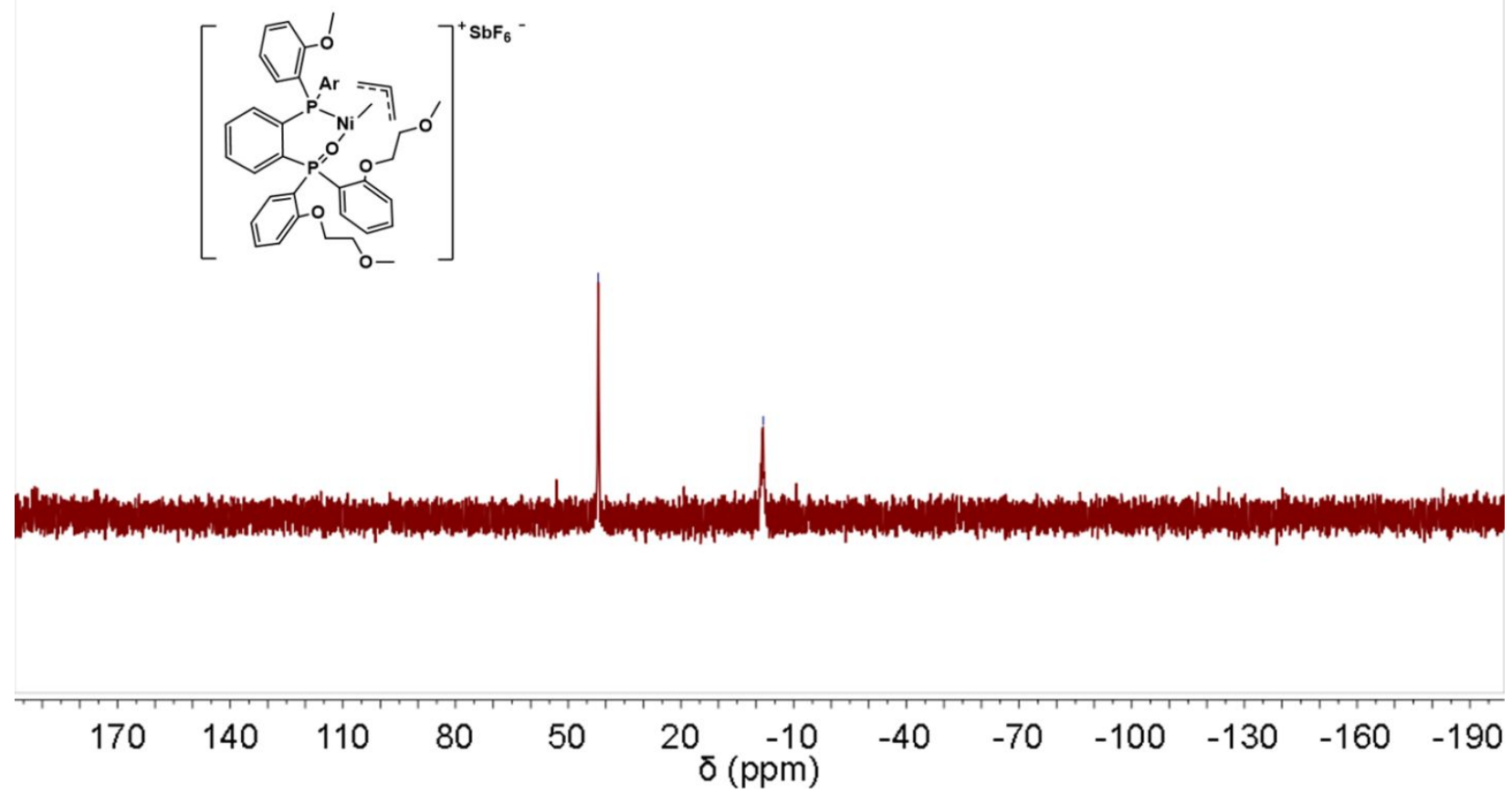

Figure S36. ${ }^{31} \mathrm{P}$ NMR spectrum $\left(\mathrm{CDCl}_{3}, 202 \mathrm{MHz}\right)$ of Ni3. 


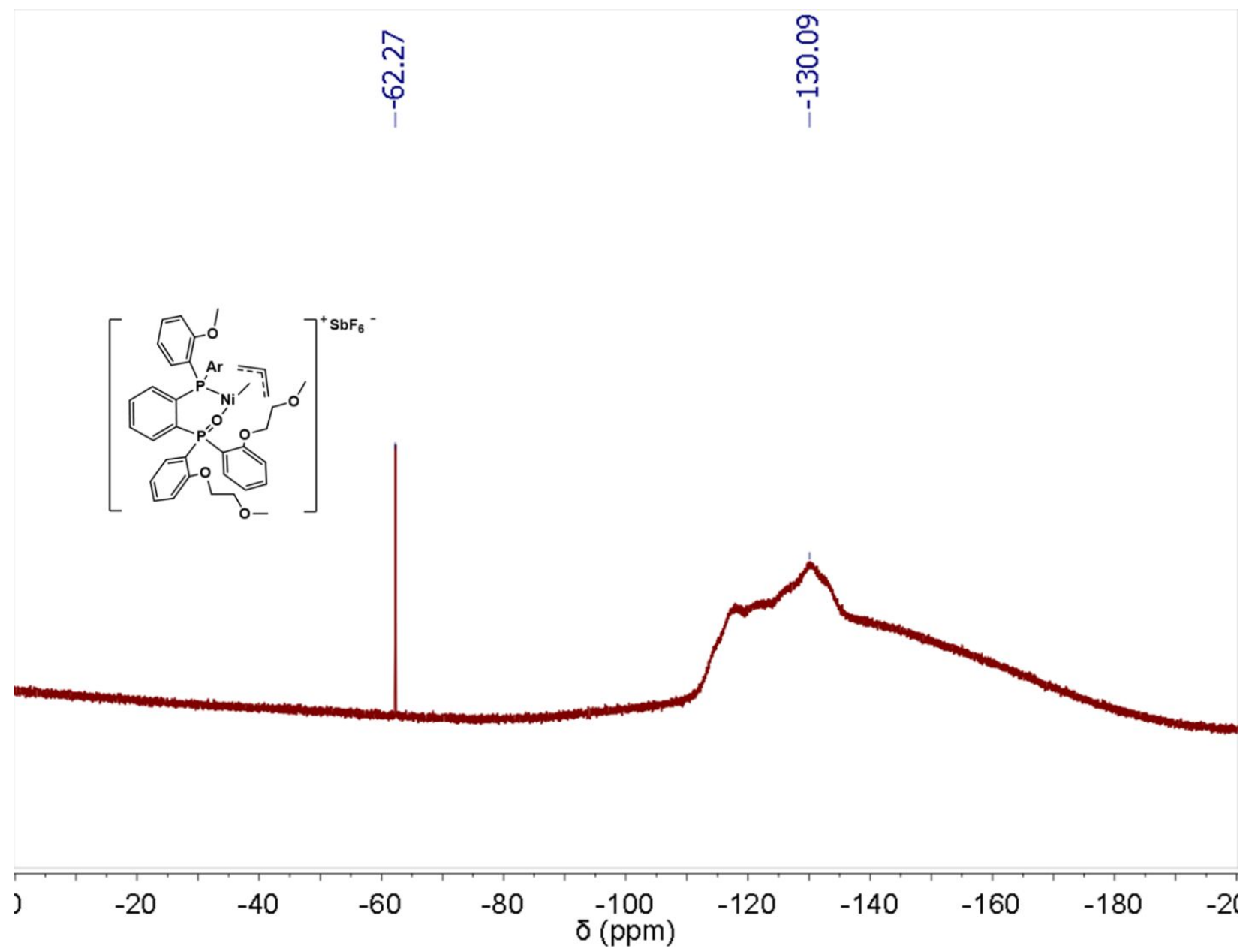

Figure S37. ${ }^{19} \mathrm{~F}$ NMR spectrum $\left(\mathrm{CDCl}_{3}, 470 \mathrm{MHz}\right)$ of Ni3. The reason for the broad peaks is unclear; we hypothesize it may be due to reversible association of $\mathrm{SbF}_{6}{ }^{-}$with the nickel center. 


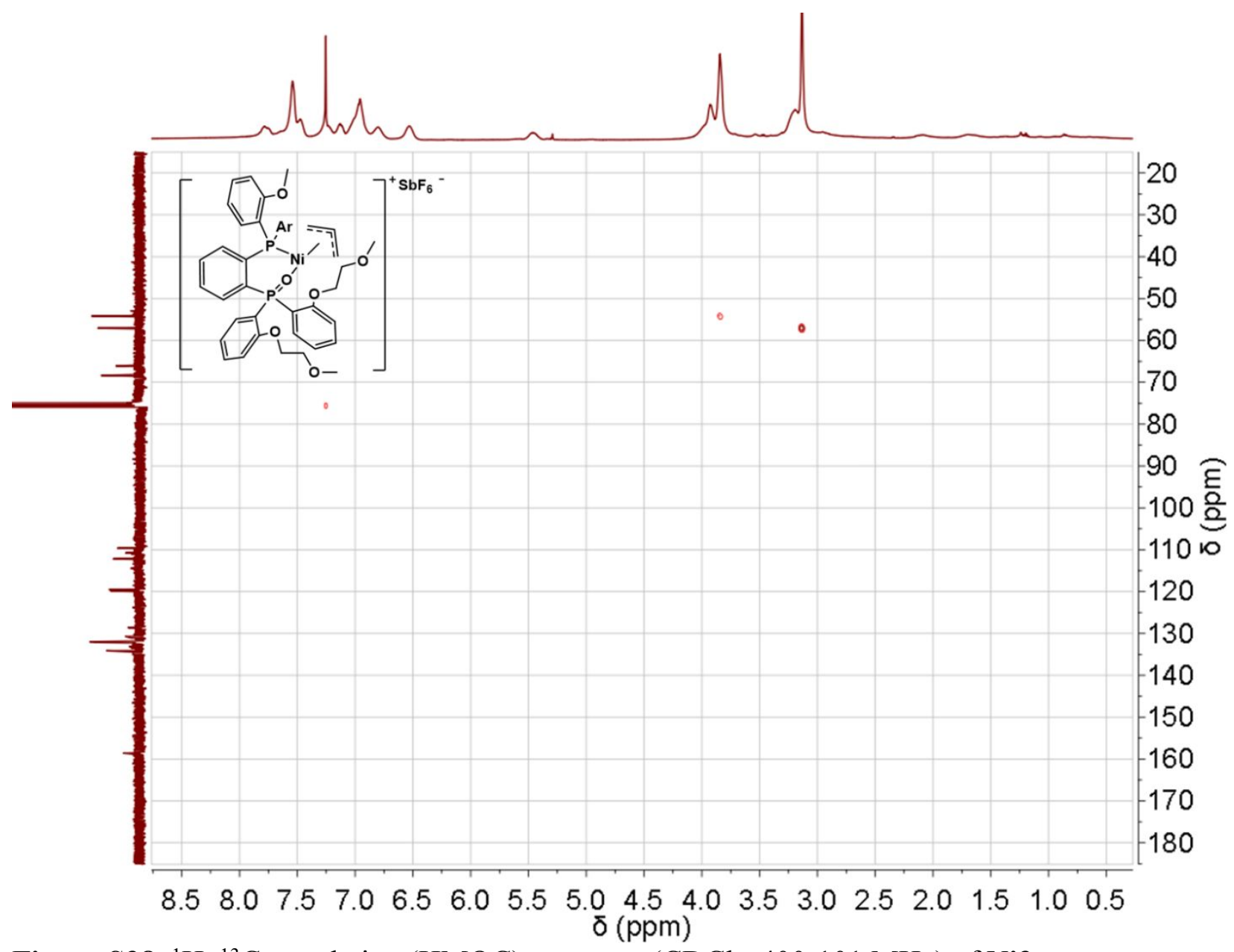

Figure S38. ${ }^{1} \mathrm{H}-{ }^{13} \mathrm{C}$ correlation (HMQC) spectrum $\left(\mathrm{CDCl}_{3}, 400-101 \mathrm{MHz}\right)$ of $\mathbf{N i 3}$. 


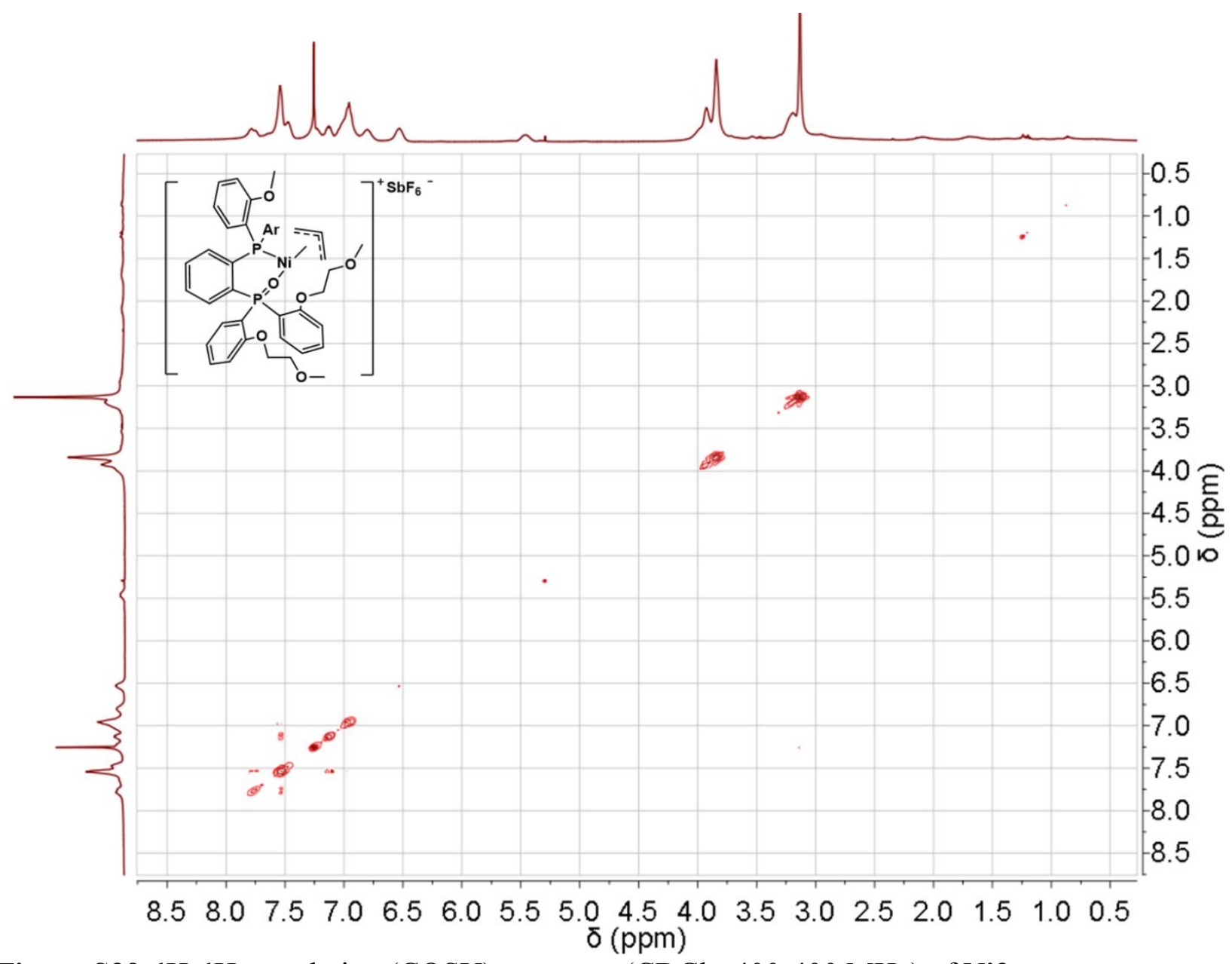

Figure S39. ${ }^{1} \mathrm{H}-{ }^{1} \mathrm{H}$ correlation (COSY) spectrum $\left(\mathrm{CDCl}_{3}, 400-400 \mathrm{MHz}\right)$ of $\mathbf{N i 3}$. 


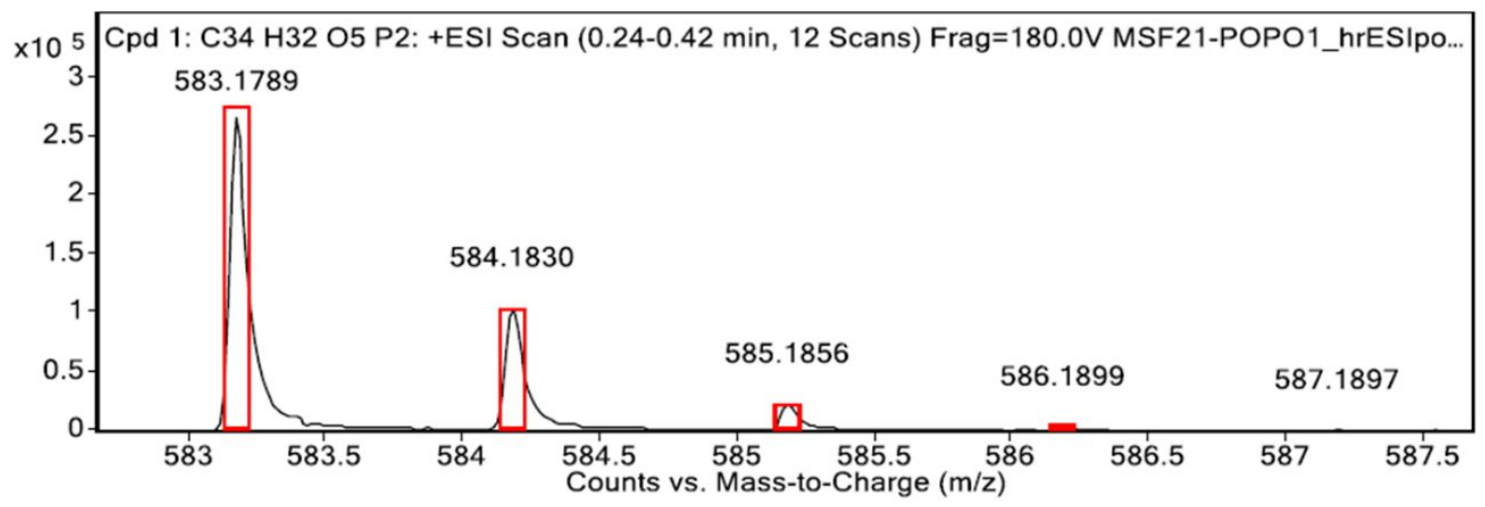

Figure S40. High-resolution mass spectrum of $6 \mathbf{a}$.

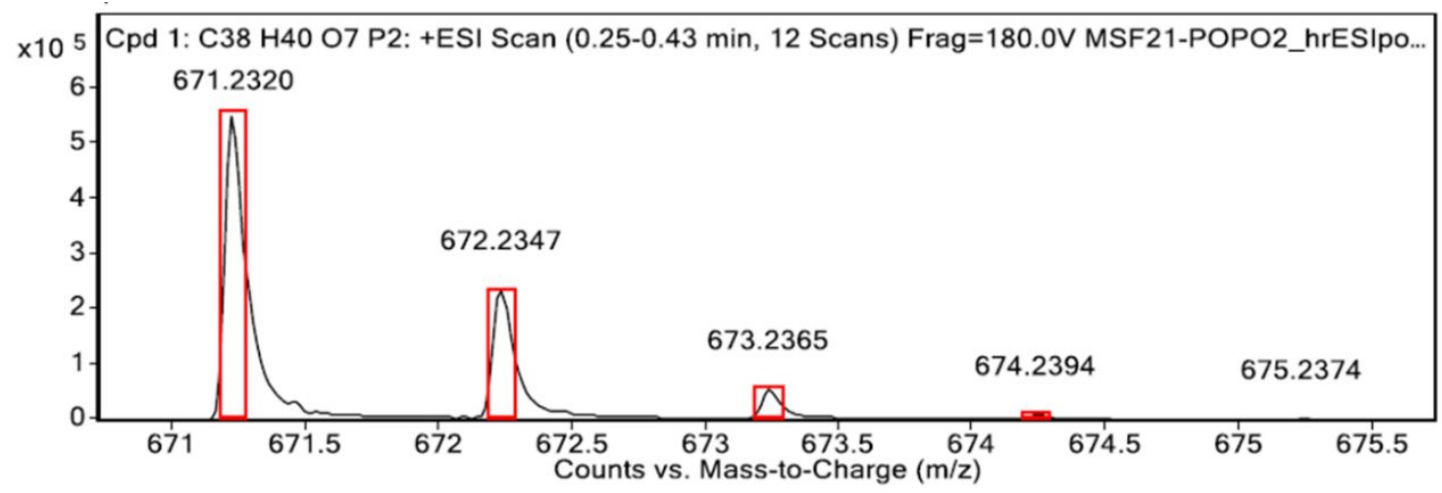

Figure S41. High-resolution mass spectrum of $\mathbf{6 b}$. 


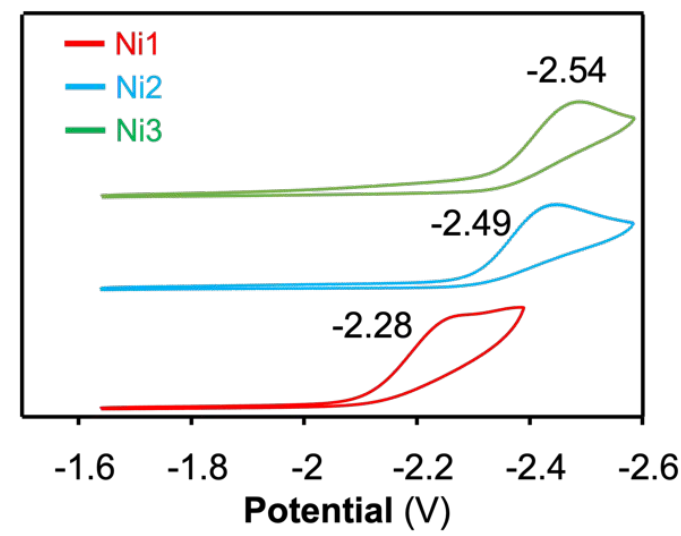

Figure S42. Cyclic voltammograms of Ni1, Ni2, and Ni3 $(10 \mu \mathrm{M})$ recorded in THF at $0.1 \mathrm{~V} / \mathrm{s}$ with $0.1 \mathrm{M}\left[\mathrm{Bu}_{4} \mathrm{~N}\right]\left[\mathrm{PF}_{6}\right]$ supporting electrolyte. The data were acquired using a glassy carbon working electrode, platinum counter electrode, and silver reference electrode. The reduction potentials measured are as follows: $\mathbf{N i 1}=-2.28, \mathbf{N i 2}=-2.49, \mathbf{N i 3}=-2.54 \mathrm{~V}(v s . \mathrm{Fc} / \mathrm{Fc}+)$. 


\section{POLYMERIZATION}

\section{General Procedure for Ethylene Polymerization}

Inside the glovebox, the nickel complex (varied), $\mathrm{B}\left(\mathrm{C}_{6} \mathrm{~F}_{5}\right)_{3}$ (varied), and alkali salts (1.1 equiv., if any) were dissolved in $10 \mathrm{~mL}$ of toluene and DCM $(8: 2 \mathrm{v}: \mathrm{v})$ and stirred for $10 \mathrm{~min}$. The mixture was loaded into a syringe equipped with an 8 -inch stainless steel needle and was sealed by sticking the needle tip into a rubber septum and brought outside of the glovebox. The mixture was injected into the Parr reactor containing $40 \mathrm{~mL}$ of dry toluene that was purged with ethylene and maintained at a specific temperature. After injection, the reactor was purged once again with ethylene at 40 psi (no stirring) three times. The reactor pressure was increased to the desired level, and the contents were stirred vigorously for various amounts of time. To stop the polymerization, the autoclave was vented and cooled. A solution of $\mathrm{MeOH}(100-200 \mathrm{~mL})$ was added to precipitate the polymer. The polymer was collected by vacuum filtration, rinsed with $\mathrm{MeOH}$, and dried under vacuum at $80{ }^{\circ} \mathrm{C}$ overnight. The reported yields are average values obtained from duplicate or triplicate runs.

\section{General Procedure for Ethylene and methyl acrylate Copolymerization}

Inside the glovebox, the nickel complex $(10 \mu \mathrm{mol}), \mathrm{B}\left(\mathrm{C}_{6} \mathrm{~F}_{5}\right)_{3}(20 \mu \mathrm{mol})$, and alkali salts (1.1 equiv., if any) were dissolved in $10 \mathrm{~mL}$ of toluene and DCM $(8: 2 \mathrm{v}: \mathrm{v})$ and stirred for $10 \mathrm{~min}$. The mixture was loaded into a syringe equipped with an 8-inch stainless steel needle and sealed by sticking the needle tip into a rubber septum and brought outside of the glovebox. The mixture was injected into the Parr reactor containing a mixture of dry toluene and methyl acrylate that was purged with ethylene and maintained at a specific temperature. After injection, the reactor was purged once again with ethylene at 40 psi (no stirring) three times. The reactor pressure was increased to the $400 \mathrm{psi}$ of ethylene, and the contents were stirred vigorously for $2 \mathrm{~h}$. To stop the polymerization, the autoclave was vented and cooled. A solution of $\mathrm{MeOH}(100-200 \mathrm{~mL})$ was added to precipitate the polymer. The polymer was collected by vacuum filtration, rinsed with $\mathrm{MeOH}$ and acetone, and dried under vacuum at $80{ }^{\circ} \mathrm{C}$ overnight. The reported yields are average values obtained from duplicate or triplicate runs. 
Table S6. Time Study of Ethylene Homopolymerization ${ }^{a}$

\begin{tabular}{ccc}
\hline Time $(\mathrm{h})$ & Activity of Ni1 $(\mathrm{kg} / \mathrm{mol} \cdot \mathrm{h})$ & Activity of Ni3 $(\mathrm{kg} / \mathrm{mol} \cdot \mathrm{h})$ \\
\hline 0.5 & 1254 & 3220 \\
1.0 & 643 & 3810 \\
1.5 & 426 & 2767
\end{tabular}

${ }^{a}$ Polymerization conditions: Ni catalyst $(1.0 \mu \mathrm{mol})$, ethylene (200 psi), $\mathrm{B}\left(\mathrm{C}_{6} \mathrm{~F}_{5}\right)_{3}(2.0$ equiv.), $2 \mathrm{~mL}$ of DCM, $48 \mathrm{~mL}$ of toluene, $1 \mathrm{~h}$ at $80^{\circ} \mathrm{C}$. The activity provided is the average of duplicate runs.

Table S7. Ethylene Polymerization without Borane Cocatalyst ${ }^{a}$

\begin{tabular}{|c|c|c|c|c|}
\hline Entry & Catalyst & Temp. $\left({ }^{\circ} \mathrm{C}\right)$ & Yield (g) & $\begin{array}{c}\text { Activity } \\
(\mathrm{kg} / \mathrm{mol} \cdot \mathrm{h})\end{array}$ \\
\hline 1 & Ni3 $(1 \mu \mathrm{mol})$ & 80 & 0 & 0 \\
\hline 2 & $\mathbf{N i 3}(1 \mu \mathrm{mol})$ & 100 & trace & 0 \\
\hline 3 & Ni3 $(10 \mu \mathrm{mol})$ & 100 & 0.916 & 91.6 \\
\hline 4 & $\begin{array}{c}\text { Ni3 }(10 \mu \mathrm{mol}) / \\
\operatorname{LiBAr}_{4}(11 \mu \mathrm{mol})\end{array}$ & 100 & 1.76 & 176 \\
\hline
\end{tabular}

Table S8. Ethylene Polymerization with Different Sodium Salts ${ }^{a}$

\begin{tabular}{ccccc}
\hline Entry & Catalyst & Salt & Yield $(\mathrm{g})$ & $\begin{array}{c}\text { Activity } \\
(\mathrm{kg} / \mathrm{mol} \cdot \mathrm{h})\end{array}$ \\
\hline 1 & $\mathbf{N i 3}$ & $\mathrm{NaBAr}_{4}$ & 1.44 & 160 \\
2 & $\mathbf{N i 3}$ & $\mathrm{NaB}_{4}\left(\mathrm{C}_{6} \mathrm{~F}_{5}\right)_{3}$ & 1.42 & 158 \\
3 & $\mathbf{N i 3}$ & $\mathrm{NaSbF}_{6}$ & 1.28 & 142
\end{tabular}

${ }^{a}$ Polymerization conditions: Ni catalyst $(9 \mu \mathrm{mol})$, ethylene $(200 \mathrm{psi}), \mathrm{B}\left(\mathrm{C}_{6} \mathrm{~F}_{5}\right)_{3}(0 \mu \mathrm{mol})$, Salt $(45 \mu \mathrm{mol})$ in $1 \mathrm{~mL}$ of acetone, $49 \mathrm{~mL}$ of toluene, $1 \mathrm{~h}$ at $100^{\circ} \mathrm{C}$. The activity provided is the average of duplicate runs. 
Table S9. Comparison of Nickel Catalysts Reported for Ethylene and Methyl Acrylate Copolymerization

\begin{tabular}{|c|c|c|c|c|c|c|c|c|c|c|}
\hline Cat. & $\begin{array}{c}\text { Cat. } \\
\text { Amount } \\
(\mu \mathrm{mol})\end{array}$ & $\begin{array}{c}\text { MA } \\
\text { (conc.) }\end{array}$ & $\begin{array}{c}\mathbf{C}_{2} \mathbf{H}_{4} \\
\text { (psi) }\end{array}$ & $\begin{array}{c}\text { Temp. } \\
\left({ }^{\circ} \mathrm{C}\right)\end{array}$ & $\begin{array}{c}\text { Time } \\
(\mathrm{h})\end{array}$ & $\begin{array}{l}\text { Yield } \\
\text { (g) }\end{array}$ & $\begin{array}{c}\text { Activity } \\
(\mathrm{kg} / \mathrm{mol} \cdot \mathrm{h})\end{array}$ & $M_{\mathrm{n}}$ & $\boldsymbol{\oplus}$ & $\begin{array}{c}\text { MA Per } \\
\text { Chain }\end{array}$ \\
\hline $\mathbf{A}(\mathrm{Ni}[P, O])^{11}$ & 20 & $1.0 \mathrm{M}$ & 116 & 80 & 6 & 0.096 & 0.8 & 0.5 & 1.2 & 0.55 \\
\hline $\mathbf{B}(\mathrm{Ni}[P, O])^{12}$ & 20 & $0.1 \mathrm{M}$ & 145 & 70 & 1 & 0.064 & 3.2 & 0.9 & 1.3 & 1.56 \\
\hline $\mathbf{C}(\mathrm{Ni}[P, O])^{13}$ & 20 & $0.1 \mathrm{M}$ & 237 & 70 & 1 & 0.078 & 3.9 & 0.7 & 1.5 & 1.64 \\
\hline D $(\mathrm{Ni}[N, N])^{14}$ & 10 & $0.12 \mathrm{M}$ & 147 & 40 & 20 & 0.100 & 0.5 & 0.3 & 1.2 & 2.17 \\
\hline $\mathbf{E}(\mathrm{Ni}[N, O])^{15}$ & 20 & $0.5 \mathrm{M}$ & 117 & 50 & 2 & 0.100 & 2.5 & 17.9 & 2.0 & 3.79 \\
\hline $\mathbf{F}(\mathrm{Ni}[P, O])^{16}$ & 20 & $1.0 \mathrm{M}$ & 117 & 80 & 6 & 0.144 & 1.2 & 4.3 & 2.8 & 4.34 \\
\hline $\mathbf{G}(\mathrm{Ni}[P, O])^{17}$ & 20 & $1.0 \mathrm{M}$ & 117 & 80 & 6 & 0.096 & 0.8 & 3.0 & 2.3 & 6.14 \\
\hline $\mathbf{H}(\mathrm{Ni}[P, O])^{18}$ & 20 & $1.0 \mathrm{M}$ & 116 & 80 & 3 & 0.120 & 2 & 4.2 & 2.1 & 9.17 \\
\hline $\mathbf{I}(\mathrm{Ni}[N, N])^{19}$ & 10 & $1.5 \mathrm{M}$ & 117 & 25 & 6 & 0.048 & 0.8 & 4.5 & 2.1 & 10.43 \\
\hline $\mathbf{J}(\mathrm{Ni}[P, O])^{20}$ & 80 & $0.04 \mathrm{M}$ & 435 & 70 & 1 & 6.880 & 86 & 34 & 2.0 & 49.98 \\
\hline Ni3 (this work) & 10 & $1.0 \mathrm{M}$ & 400 & 80 & 2 & 0.036 & 1.8 & 2.2 & 1.4 & 1.80 \\
\hline Ni3-Li (this work) & 10 & $1.0 \mathrm{M}$ & 400 & 80 & 2 & 0.196 & 9.8 & 2.5 & 1.5 & 3.68 \\
\hline
\end{tabular}




\section{Methyl Acrylate Incorporation Calculations}

Methyl acrylate incorporation calculation was performed through ${ }^{1} \mathrm{H}$ NMR spectroscopy using the following equation. ${ }_{-}^{4}$

Equation S11. General expression for incorporation mol\% of methyl acrylate:

$$
\text { incorporation }(\mathrm{mol} \%)=\frac{\left(\mathrm{H}_{\mathrm{a}} / 3\right)}{\left(\mathrm{H}_{\mathrm{a}} / 3\right)+\left(\mathrm{I}_{\text {tot }}-2 \mathrm{H}_{\mathrm{a}}\right) / 4} \times 100 \%
$$

Where:

$\mathrm{I}_{\text {tot }}=$ total integration of all hydrogen signals.

$\mathrm{H}_{\mathrm{a}}=$ the peak at $\sim 3.7$ ppm corresponding to the methyl $\mathrm{CH}_{3}(\mathrm{COO})$ - hydrogens in methyl acrylate

Equation S12. Expression for calculating number of methyl acrylate per chain:

$$
\frac{\text { total moles of MA }}{\text { total moles of polymers }}=\frac{[\text { polymer yield }] /[(28(1-\text { Inc })) / \text { Inc }+86]}{\left[\text { polymer yield } / \text { polymer } M_{\mathrm{n}}\right]}
$$

*Total moles of MA derived from combining the following relationships:

I. Polymer yield $=28 \mathrm{~g} / \mathrm{mol} \times($ total moles of ethylene $)+86 \mathrm{~g} / \mathrm{mol} \times($ total moles of MA $)$

II. $\frac{\text { total moles of ethylene }}{\text { total moles of MA }}=\frac{1-\text { Inc }}{\mathrm{I}}$

Where:

Inc $=\operatorname{Inc} \% / 100$ 


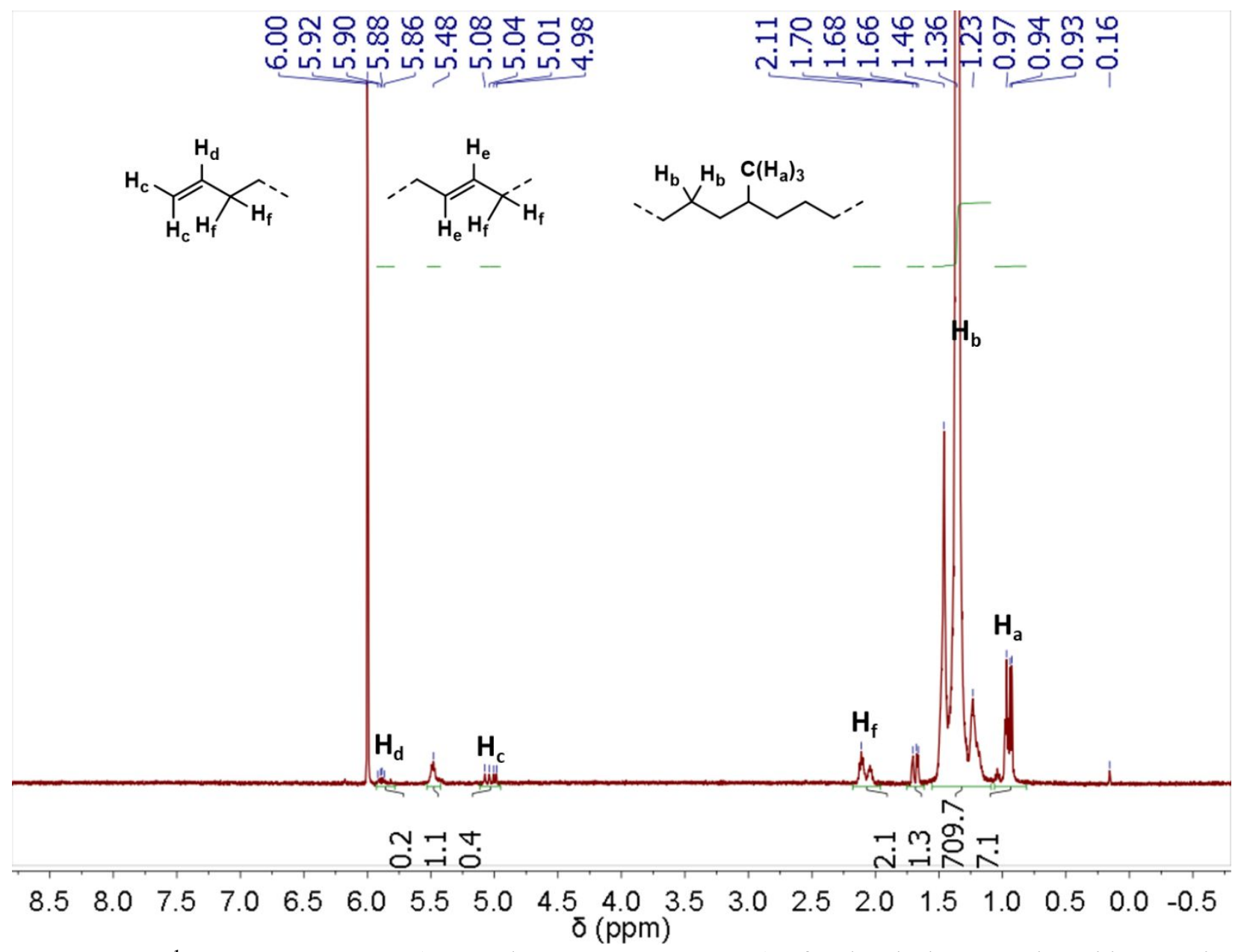

Figure S43. ${ }^{1} \mathrm{H}$ NMR spectrum $\left(\mathrm{C}_{2} \mathrm{D}_{2} \mathrm{Cl}_{4}, 500 \mathrm{MHz}, 120^{\circ} \mathrm{C}\right)$ of polyethylene produced by $\mathrm{Ni3}$ in DCM/toluene (Table 2, entry 17). Polymerization conditions: Ni3 (1.0 $\mu \mathrm{mol})$, ethylene (200 psi), $\mathrm{B}\left(\mathrm{C}_{6} \mathrm{~F}_{5}\right)_{3}\left(2.0\right.$ equiv.), $\mathrm{CsBAr}_{4}{ }_{4}$ (1.1 equiv.), $2 \mathrm{~mL}$ DCM, $48 \mathrm{~mL}$ toluene, $1 \mathrm{~h}$ at $80^{\circ} \mathrm{C}$. 


\section{กิ}

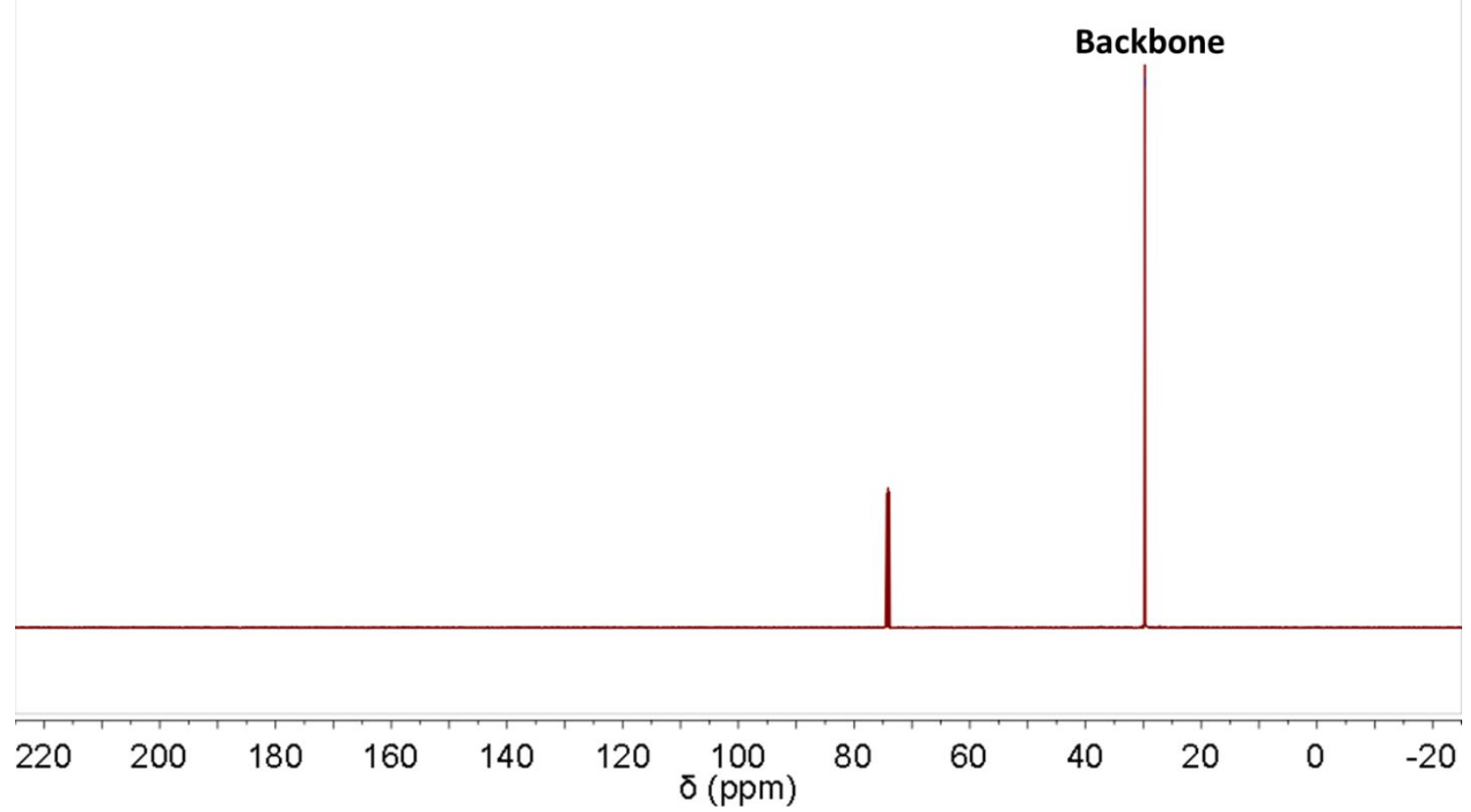

Figure S44. ${ }^{13} \mathrm{C}$ NMR spectrum $\left(\mathrm{C}_{2} \mathrm{D}_{2} \mathrm{Cl}_{4}, 125 \mathrm{MHz}, 120{ }^{\circ} \mathrm{C}\right)$ of polyethylene produced by $\mathrm{Ni} 2$ in DCM/toluene (Table 2, entry 6). Polymerization conditions: Ni2 (1.0 $\mu \mathrm{mol})$, ethylene (200 psi), $\mathrm{B}\left(\mathrm{C}_{6} \mathrm{~F}_{5}\right)_{3}(2.0$ equiv. $), 2 \mathrm{~mL} \mathrm{DCM}, 48 \mathrm{~mL}$ toluene, $1 \mathrm{~h}$ at $80^{\circ} \mathrm{C}$. 


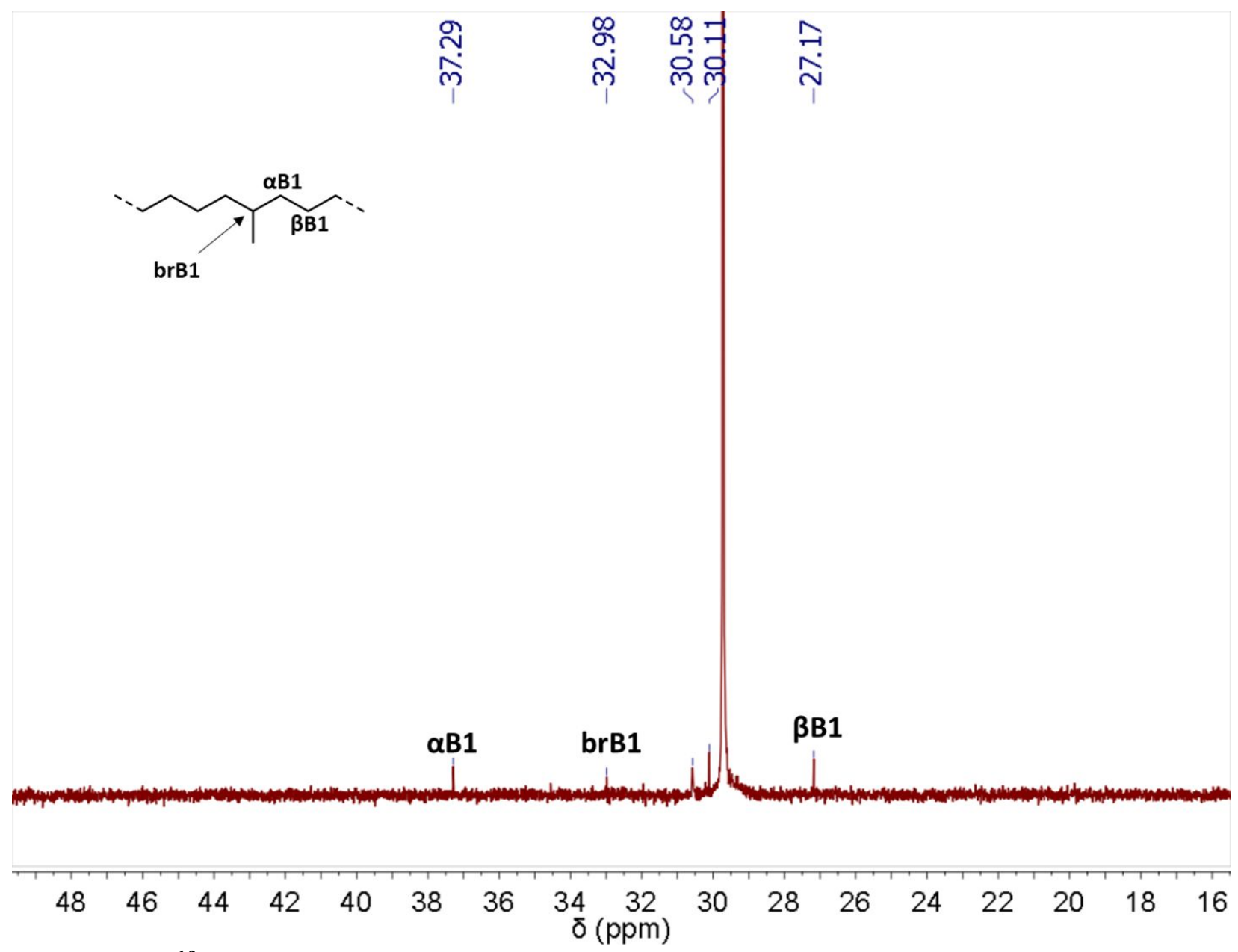

Figure S45. ${ }^{13} \mathrm{C}$ NMR spectrum $\left(\mathrm{C}_{2} \mathrm{D}_{2} \mathrm{Cl}_{4}, 125 \mathrm{MHz}, 120^{\circ} \mathrm{C}\right)$ of polyethylene produced by $\mathrm{Ni} 2$ in DCM/toluene (Table 2, entry 6). Polymerization conditions: Ni2 (1.0 $\mu \mathrm{mol})$, ethylene (200 psi), $\mathrm{B}\left(\mathrm{C}_{6} \mathrm{~F}_{5}\right)_{3}$ (2.0 equiv.), $2 \mathrm{~mL} \mathrm{DCM}, 48 \mathrm{~mL}$ toluene, $1 \mathrm{~h}$ at $80{ }^{\circ} \mathrm{C}$. 


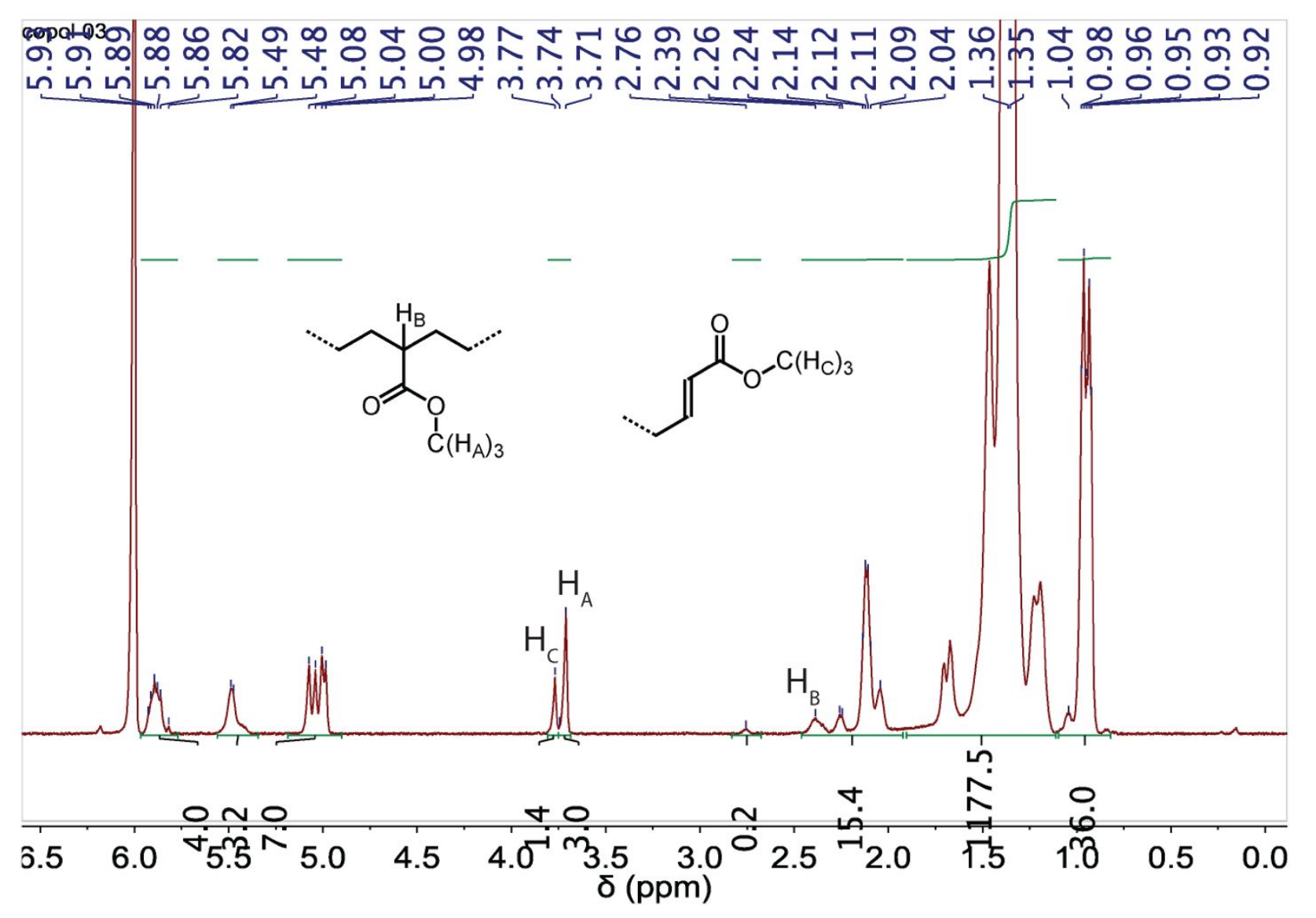

Figure S46. ${ }^{1} \mathrm{H}$ NMR spectrum $\left(\mathrm{C}_{2} \mathrm{D}_{2} \mathrm{Cl}_{4}, 500 \mathrm{MHz}, 120{ }^{\circ} \mathrm{C}\right)$ of ethylene and methyl acrylate copolymer produced by Ni1 in DCM/toluene (Table 3, entry 4). Polymerization conditions: Ni1 (10 $\mu \mathrm{mol}$ ), ethylene (400 psi), $\mathrm{B}\left(\mathrm{C}_{6} \mathrm{~F}_{5}\right)_{3}$ (2.0 equiv.), $\operatorname{LiBAr}_{4}$ (1.1 equiv.), $2 \mathrm{~mL} \mathrm{DCM,} 48 \mathrm{~mL}$ toluene, $\mathrm{MA}(0.1 \mathrm{M}), 2 \mathrm{~h}$ at $80^{\circ} \mathrm{C}$. 


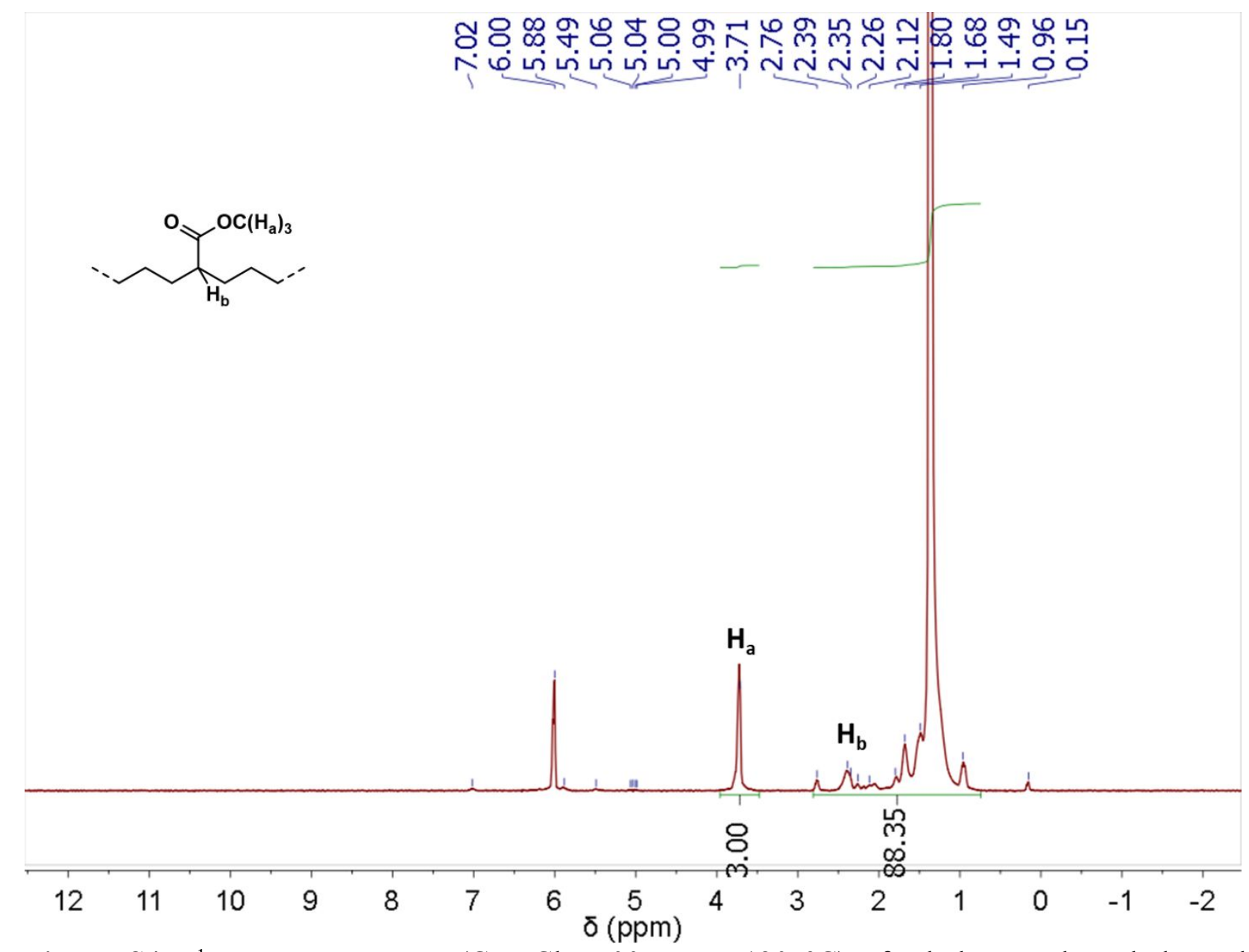

Figure S47. ${ }^{1} \mathrm{H}$ NMR spectrum $\left(\mathrm{C}_{2} \mathrm{D}_{2} \mathrm{Cl}_{4}, 500 \mathrm{MHz}, 120{ }^{\circ} \mathrm{C}\right)$ of ethylene and methyl acrylate copolymer produced by Ni3 in DCM/toluene (Table 3, entry 14). Polymerization conditions: Ni3 (10 $\mu \mathrm{mol}$ ), ethylene (400 psi), $\mathrm{B}\left(\mathrm{C}_{6} \mathrm{~F}_{5}\right)_{3}$ (2.0 equiv.), $\operatorname{LiBAr}_{4}$ (1.1 equiv.), $2 \mathrm{~mL} \mathrm{DCM,} 48 \mathrm{~mL}$ toluene, $\mathrm{MA}(1.0 \mathrm{M}), 2 \mathrm{~h}$ at $80{ }^{\circ} \mathrm{C}$. 


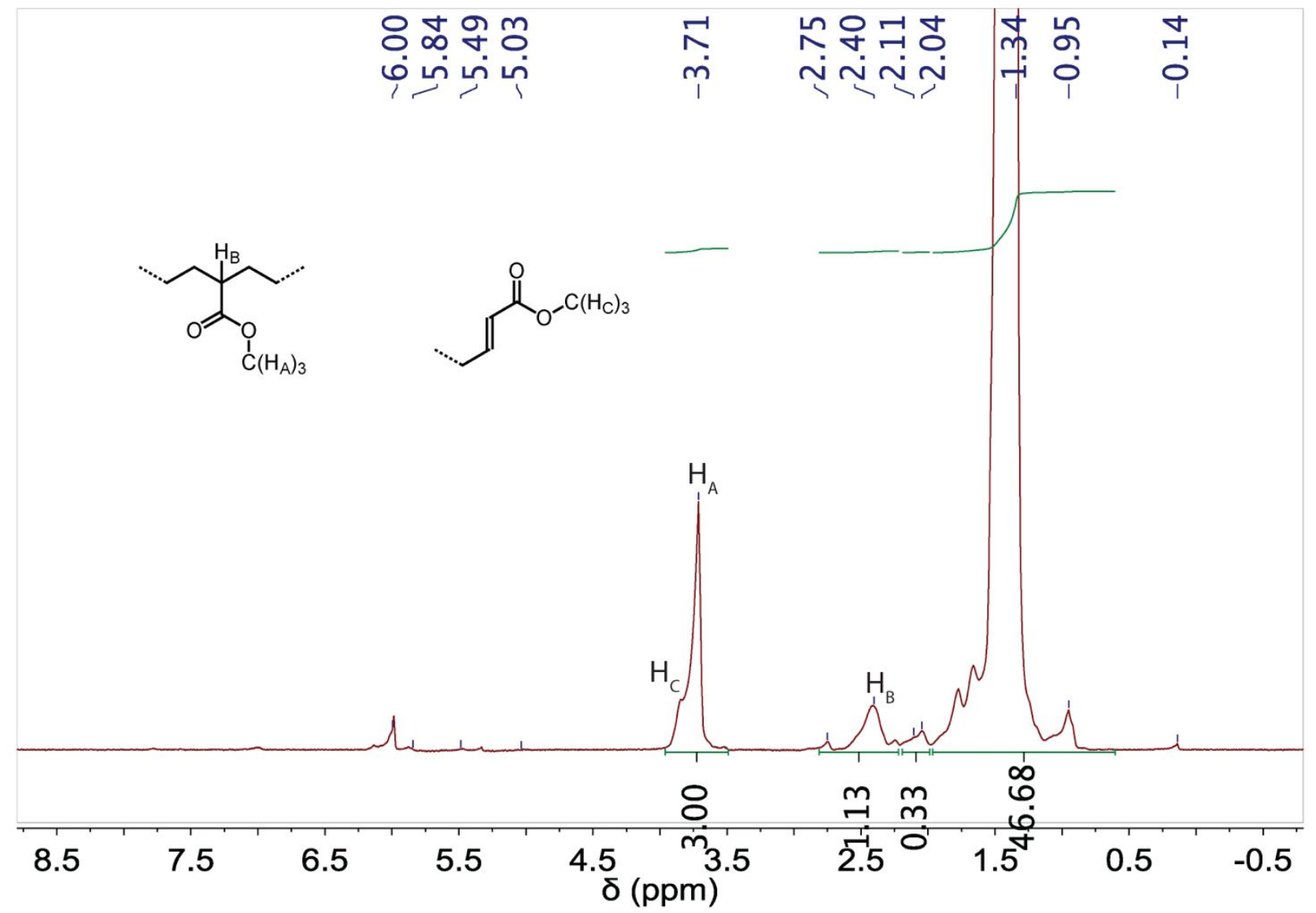

Figure S48. ${ }^{1} \mathrm{H}$ NMR spectrum $\left(\mathrm{C}_{2} \mathrm{D}_{2} \mathrm{Cl}_{4}, 500 \mathrm{MHz}, 120^{\circ} \mathrm{C}\right)$ of ethylene and methyl acrylate copolymer produced by Ni3 in DCM/toluene (Table 3, entry 15). Polymerization conditions: Ni3 (10 $\mu \mathrm{mol}$ ), ethylene (400 psi), $\mathrm{B}\left(\mathrm{C}_{6} \mathrm{~F}_{5}\right)_{3}$ (2.0 equiv.), $\mathrm{NaBAr}_{4}{ }_{4}$ (1.1 equiv.), $2 \mathrm{~mL} \mathrm{DCM}, 48 \mathrm{~mL}$ toluene, $\mathrm{MA}(1.0 \mathrm{M}), 2 \mathrm{~h}$ at $80^{\circ} \mathrm{C}$. 

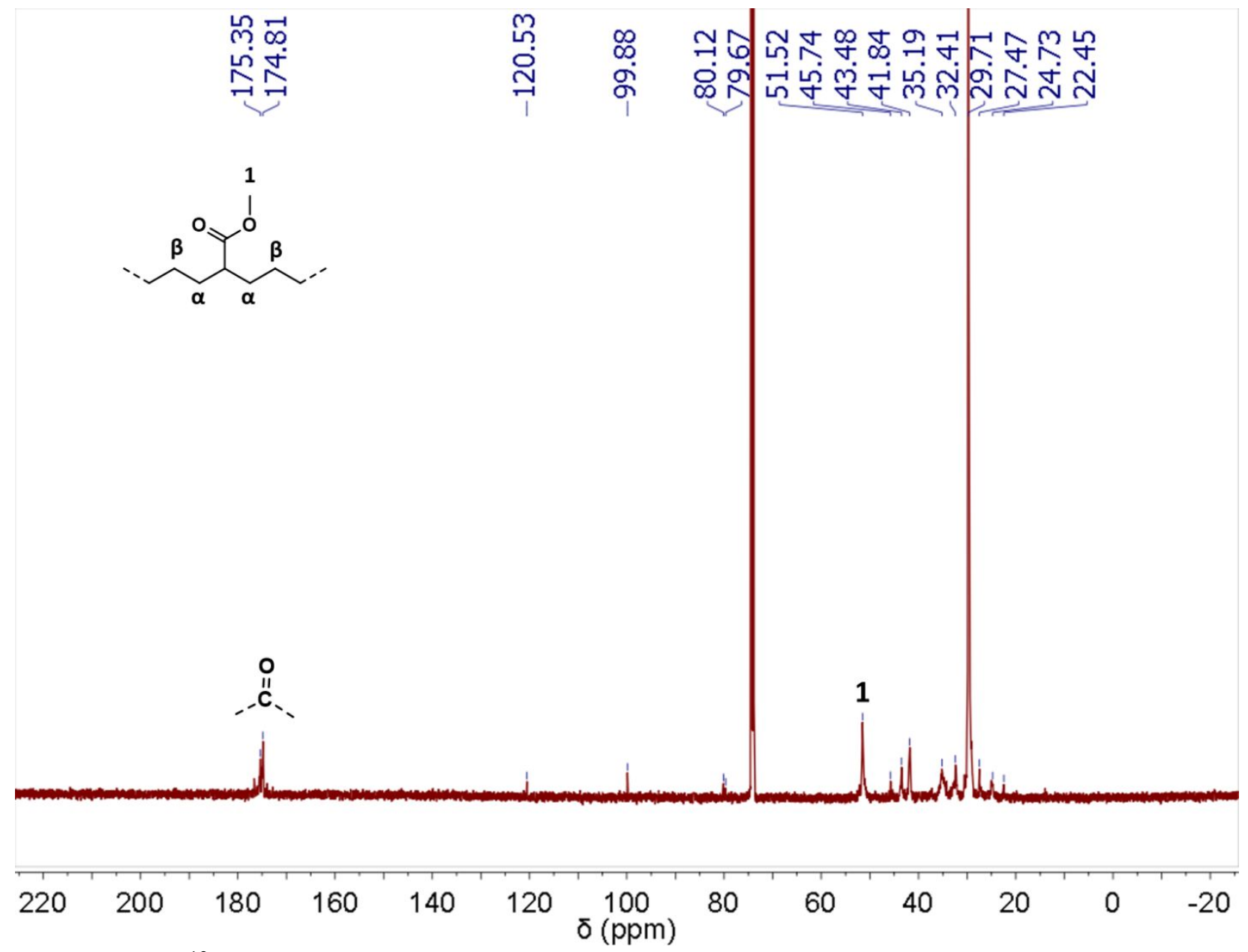

Figure S49. ${ }^{13} \mathrm{C}$ NMR spectrum $\left(\mathrm{C}_{2} \mathrm{D}_{2} \mathrm{Cl}_{4}, 125 \mathrm{MHz}, 120{ }^{\circ} \mathrm{C}\right)$ of ethylene and methyl acrylate copolymer produced by Ni3 in DCM/toluene (Table 3, entry 15). Polymerization conditions: Ni3 (10 $\mu \mathrm{mol}$ ), ethylene (400 psi), $\mathrm{B}\left(\mathrm{C}_{6} \mathrm{~F}_{5}\right)_{3}$ (2.0 equiv.), $\mathrm{NaBAr}_{4}{ }_{4}$ (1.1 equiv.), $2 \mathrm{~mL} \mathrm{DCM,} 48 \mathrm{~mL}$ toluene, $\mathrm{MA}(1.0 \mathrm{M}), 2 \mathrm{~h}$ at $80^{\circ} \mathrm{C}$. 

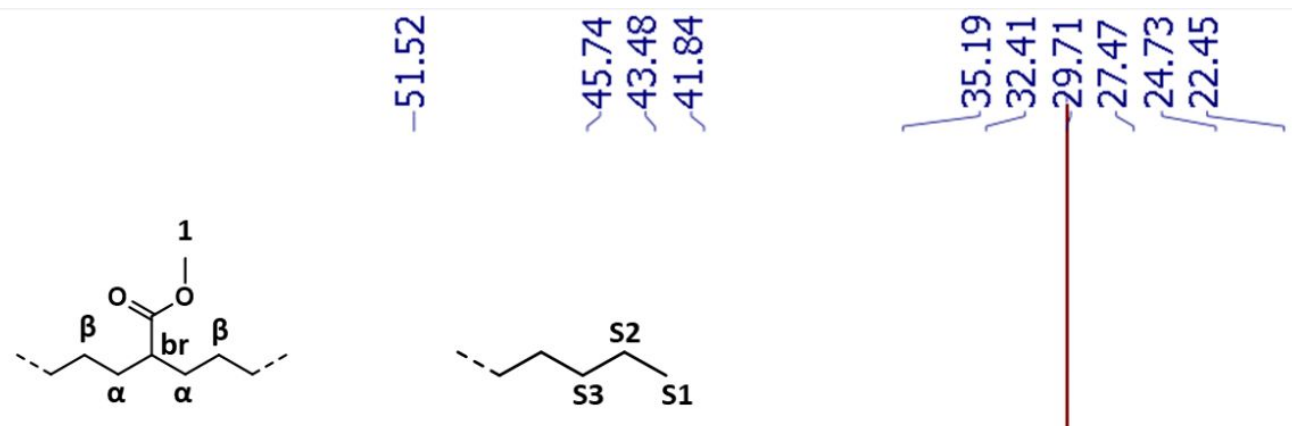

65

60

55

50

$45(\mathrm{ppm})$

35

30

25

20

Figure S50. ${ }^{13} \mathrm{C}$ NMR spectrum $\left(\mathrm{C}_{2} \mathrm{D}_{2} \mathrm{Cl}_{4}, 125 \mathrm{MHz}, 120{ }^{\circ} \mathrm{C}\right)$ of ethylene and methyl acrylate copolymer produced by Ni3 in DCM/toluene (Table 3, entry 15). Polymerization conditions: Ni3 (10 $\mu \mathrm{mol}$ ), ethylene (400 psi), $\mathrm{B}\left(\mathrm{C}_{6} \mathrm{~F}_{5}\right)_{3}$ (2.0 equiv.), $\mathrm{NaBAr}_{4} \mathrm{~F}_{4}$ (1.1 equiv.), $2 \mathrm{~mL} \mathrm{DCM}, 48 \mathrm{~mL}$ toluene, $\mathrm{MA}(1.0 \mathrm{M}), 2 \mathrm{~h}$ at $80^{\circ} \mathrm{C}$. 


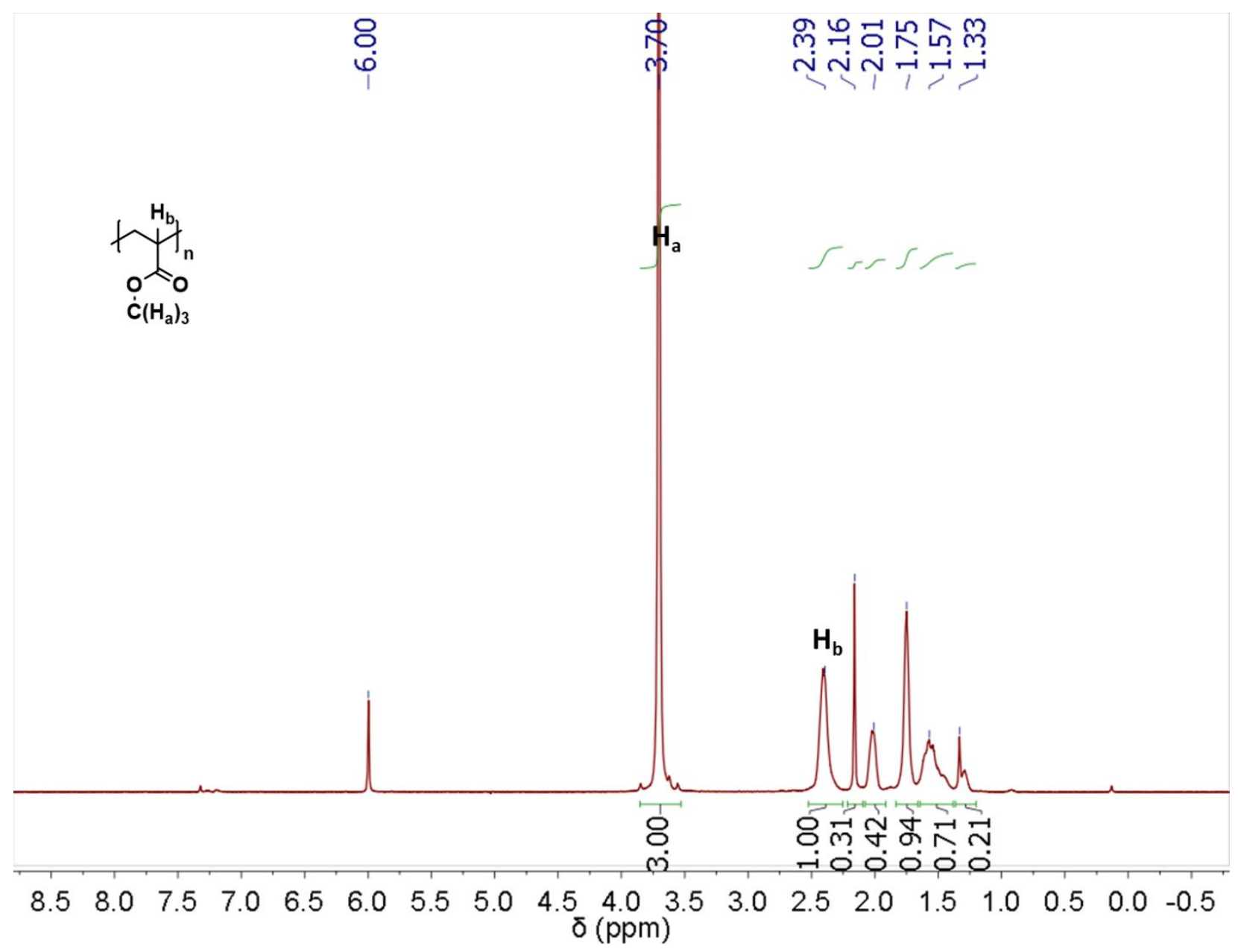

Figure S51. ${ }^{1} \mathrm{H}$ NMR spectrum $\left(\mathrm{C}_{2} \mathrm{D}_{2} \mathrm{Cl}_{4}, 500 \mathrm{MHz}, 120{ }^{\circ} \mathrm{C}\right)$ of poly(methyl acrylate) produced by Ni3 in DCM/toluene. 


\section{GEL PERMEATION CHROMATOGRAPHY (GPC)}

Gel permeation chromatography (GPC) data were obtained using a Malvern high temperature GPC instrument equipped with refractive index, viscometer, and light scattering detectors at $160{ }^{\circ} \mathrm{C}$ with 1,2,4-trichlorobenzene, stabilized with $125 \mathrm{ppm}$ BHT, as the mobile phase. A calibration curve was established using polystyrene standards in triple detection mode. All molecular weights reported are based on triple detection.
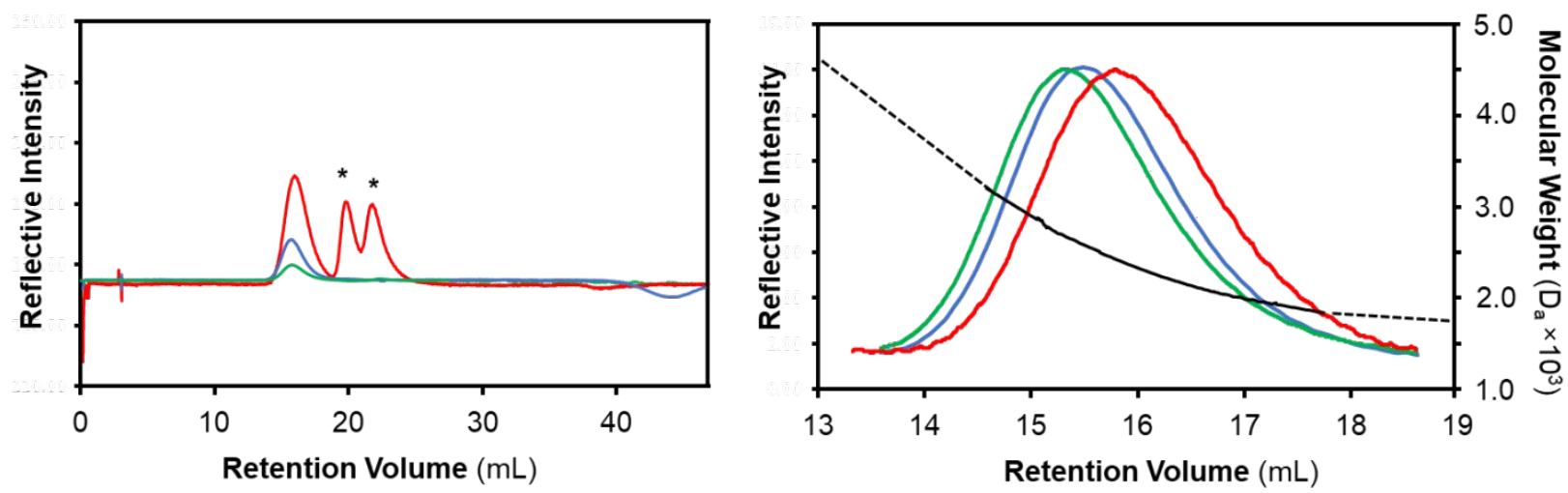

Figure S52. GPC traces of the polyethylene obtained from ethylene polymerization using Ni3 (Table 2 , entry 8). B) Normalized chromatograms showing the peaks corresponding to the polymer and the molecular weight range (right). The data were acquired using a triple detector system: refractive index (red), right angle light scattering (green), viscometer (blue). The peaks marked with asterisk $\left({ }^{*}\right)$ are derived from a contaminant in the GPC column, not the sample itself.
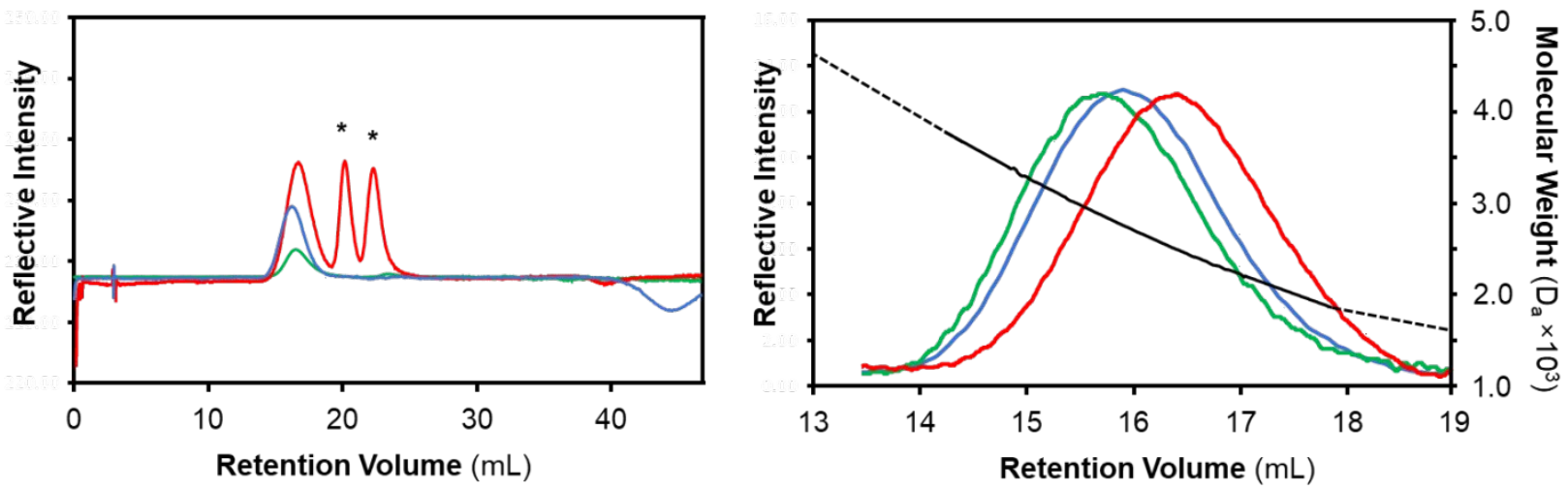

Figure S53. GPC traces of the polyethylene obtained from ethylene polymerization using Ni2 (Table 2 , entry 4). Normalized chromatograms showing the peaks corresponding to the polymer and the molecular weight range (right). The data were acquired using a triple detector system: refractive index (red), right angle light scattering (green), viscometer (blue). The peaks marked with asterisk $\left({ }^{*}\right)$ are derived from a contaminant in the GPC column, not the sample itself. 

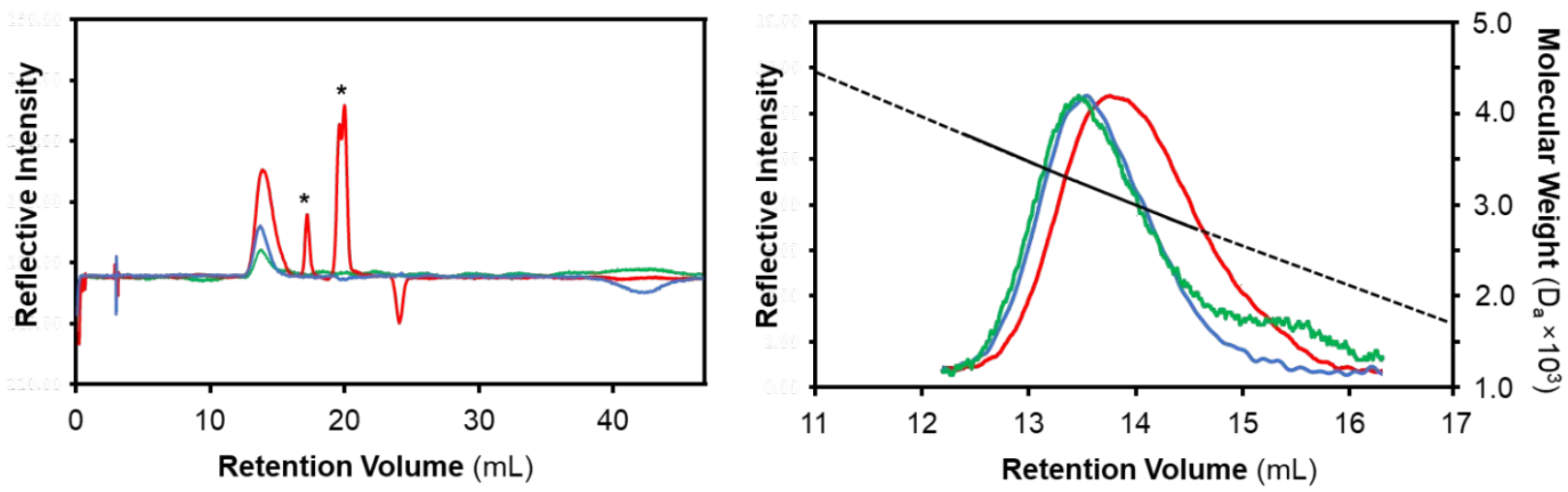

Figure S54. GPC traces of the polyethylene obtained from ethylene polymerization using Ni3 (Table 3 , entry 10). Normalized chromatograms showing the peaks corresponding to the polymer and the molecular weight range (right). The data were acquired using a triple detector system: refractive index (red), right angle light scattering (green), viscometer (blue). The peaks marked with asterisk $(*)$ are derived from a contaminant in the GPC column, not the sample itself.
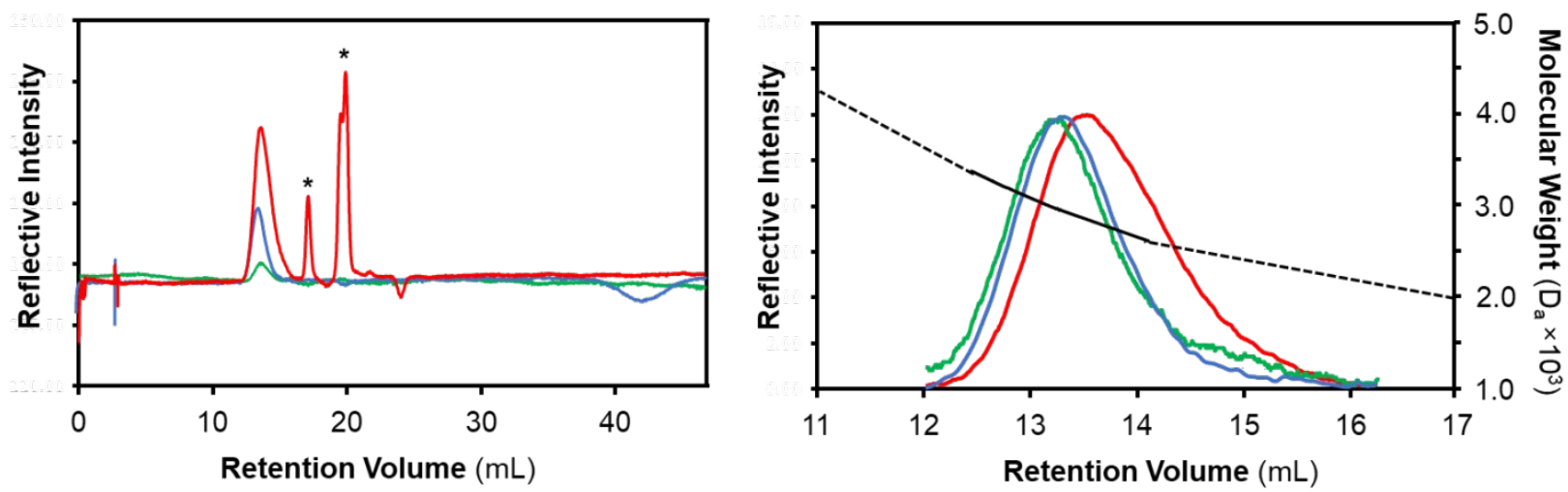

Figure S55. GPC traces of the polyethylene obtained from ethylene polymerization using Ni3 (Table 3 , entry 8). Normalized chromatograms showing the peaks corresponding to the polymer and the molecular weight range (right). The data were acquired using a triple detector system: refractive index (red), right angle light scattering (green), viscometer (blue). The peaks marked with asterisk $\left(^{*}\right)$ are derived from a contaminant in the GPC column, not the sample itself. 

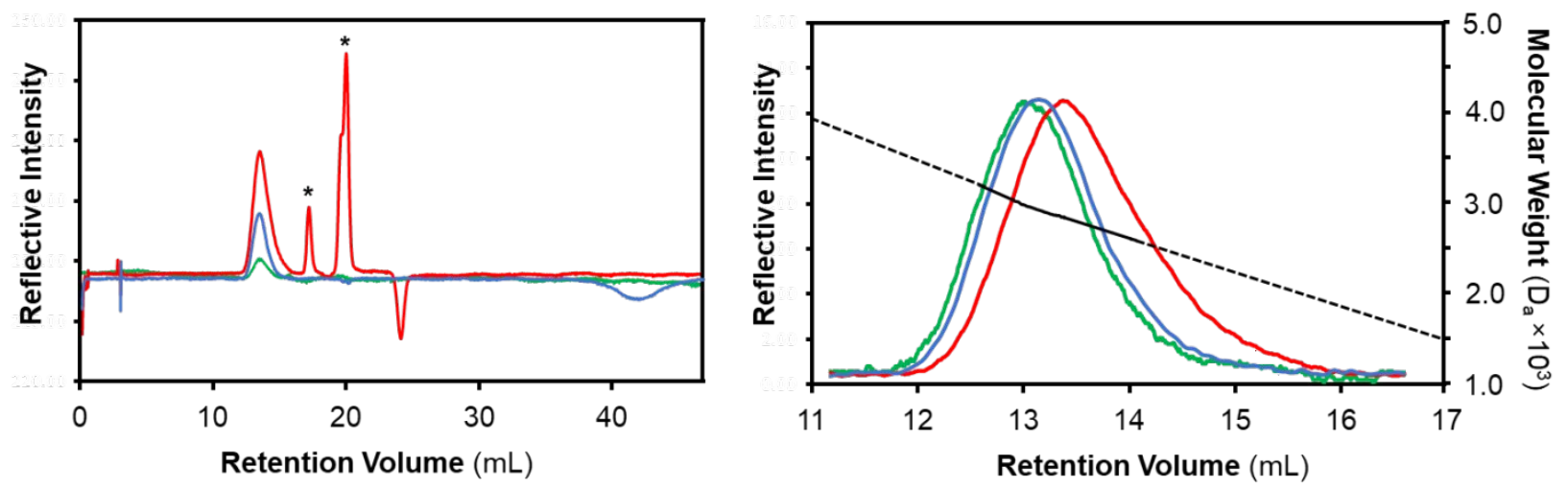

Figure S56. GPC traces of the polyethylene obtained from ethylene polymerization using $\mathbf{N i 3} / \mathrm{Li}^{+}$ (Table 3, entry 12). Normalized chromatograms showing the peaks corresponding to the polymer and the molecular weight range (right). The data were acquired using a triple detector system: refractive index (red), right angle light scattering (green), viscometer (blue). The peaks marked with asterisk $\left(^{*}\right.$ ) are derived from a contaminant in the GPC column, not the sample itself.
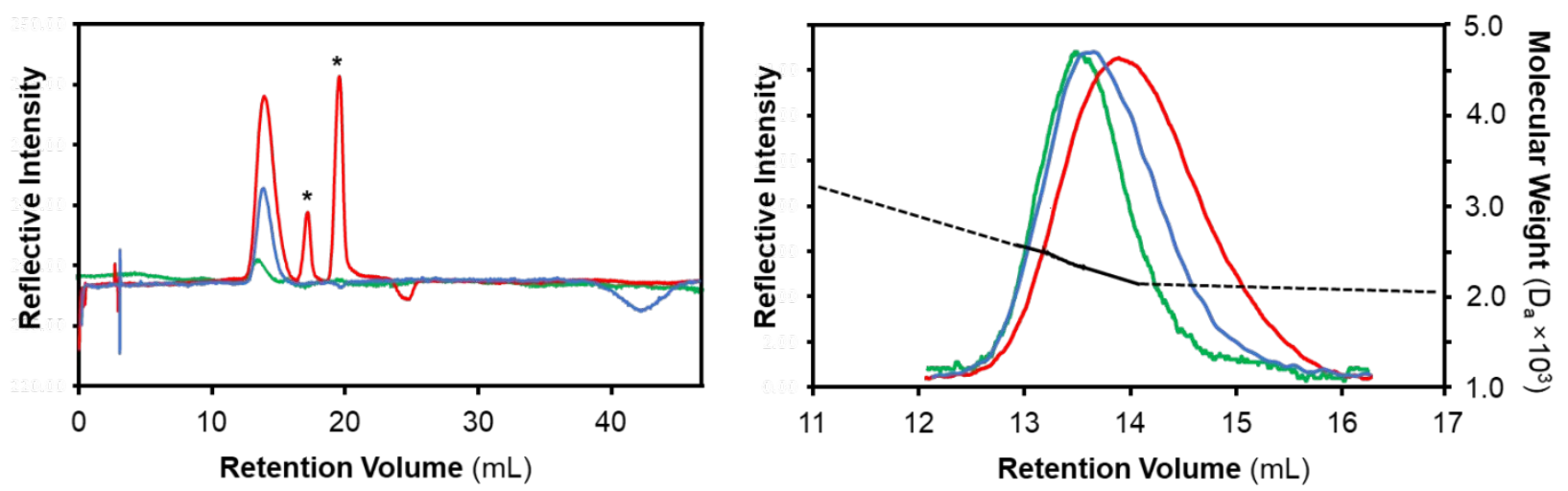

Figure S57. GPC chromatograms of the polyethylene obtained from ethylene polymerization using $\mathrm{Ni3} / \mathrm{Li}^{+}$(Table 3, entry 14). Normalized chromatograms showing the peaks corresponding to the polymer and the molecular weight range (right). The data were acquired using a triple detector system: refractive index (red), right angle light scattering (green), viscometer (blue). The peaks marked with asterisk $\left(^{*}\right)$ are derived from a contaminant in the GPC column, not the sample itself. 
A)
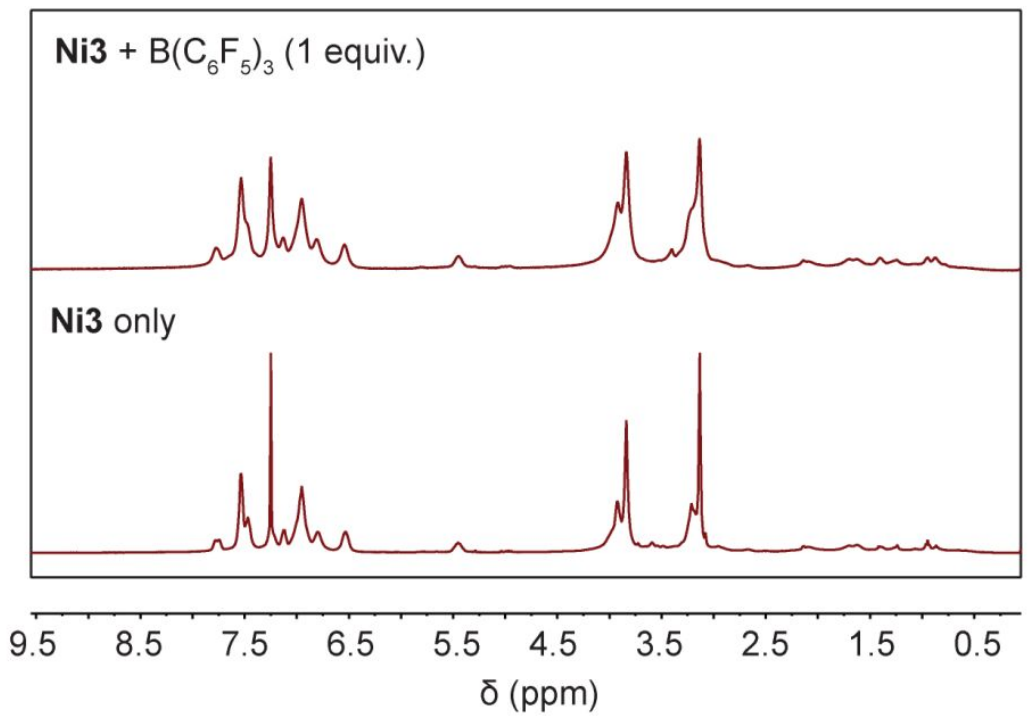

B)

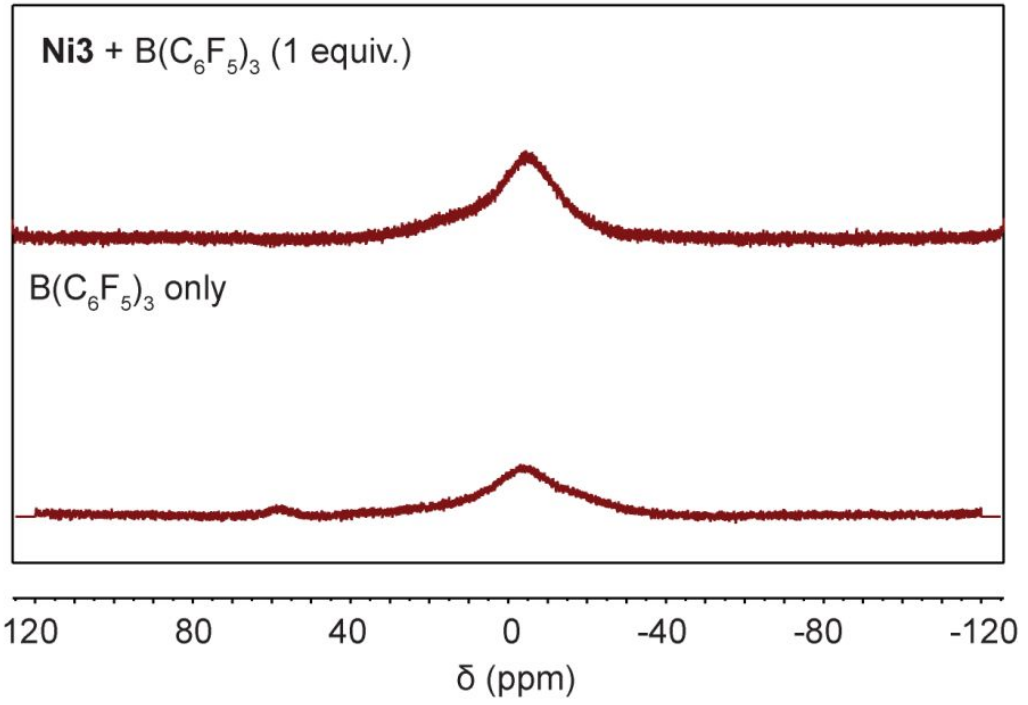

Figure S58. A) ${ }^{1} \mathrm{H}$ NMR spectra $\left(\mathrm{CDCl}_{3}, 400 \mathrm{MHz}, 25^{\circ} \mathrm{C}\right)$ of $\mathbf{N i 3}$ and $\mathbf{N i 3} / \mathrm{B}\left(\mathrm{C}_{6} \mathrm{~F}_{5}\right)_{3}$ and $\left.\mathrm{B}\right){ }^{11} \mathrm{~B}$ NMR spectra $\left(\mathrm{CDCl}_{3}, 128 \mathrm{MHz}, 25^{\circ} \mathrm{C}\right)$ of $\mathrm{Ni3} / \mathrm{B}\left(\mathrm{C}_{6} \mathrm{~F}_{5}\right)_{3}$ and $\mathrm{B}\left(\mathrm{C}_{6} \mathrm{~F}_{5}\right)_{3}$. These results suggest that at room temperature $\mathrm{B}\left(\mathrm{C}_{6} \mathrm{~F}_{5}\right)_{3}$ cannot activate the nickel complex and has minimal interactions with the oxygen donors (e.g., from methoxy or PEG groups) in the ligand structure. 


\section{X-RAY DATA COLLECTION AND REFINEMENT}

Crystals suitable for X-ray diffraction analysis were picked out of the crystallization vials and mounted onto Mitogen loops using Paratone oil and then frozen under a nitrogen stream at $-150{ }^{\circ} \mathrm{C}$ during data collection. The crystals were collected at a $6.0 \mathrm{~cm}$ detector distance. The structures were solved by direct methods using the program SHELXT and refined by SHELXLE. Hydrogen atoms connected to carbon were placed at idealized positions using standard riding models and refined isotropically. All non-hydrogen atoms were refined anisoptriocally. Single crystals of $\mathbf{N i} 2$ and $\mathbf{N i 3}$ were obtained via slow diffusion of pentane into a solution of the complex in dichloromethane. Both structures contain a single free $\mathrm{SbF}_{6}{ }^{-}$anion. No solvent molecules were found in the crystal lattices. The molecular structure of Ni2 contains an allyl group that was modeled with a two-part positional disorder for the entire group (C35-C37, 64:36). The molecular structure of Ni3 contains an allyl group (C39-C41) that was modeled with positional disorder at $\mathrm{C} 40$ (66:34). The $\mathrm{SbF}_{6}{ }^{-}$anion also showed positional disorder and was modeled accordingly $(56: 44)$.

Table S10. Representative Bond Lengths ( $\AA$ ) and Angles (deg) in Ni2 and Ni3

\begin{tabular}{ccccccc}
\hline & Ni(1)-C(1) & Ni(1)-C(2) & Ni(1)-P(2) & Ni(1)-O(1) & P(2)-Ni(1)-O(1) & C(1)-Ni(1)-C(2) \\
\hline Ni2 & $2.0041(111)$ & $2.0461(100)$ & $2.2038(8)$ & $1.8814(24)$ & $97.630(78)$ & $72.717(375)$ \\
Ni3 & $1.9817(25)$ & $2.0734(29)$ & $2.1842(7)$ & $1.9061(14)$ & $91.131(48)$ & $72.145(104)$
\end{tabular}



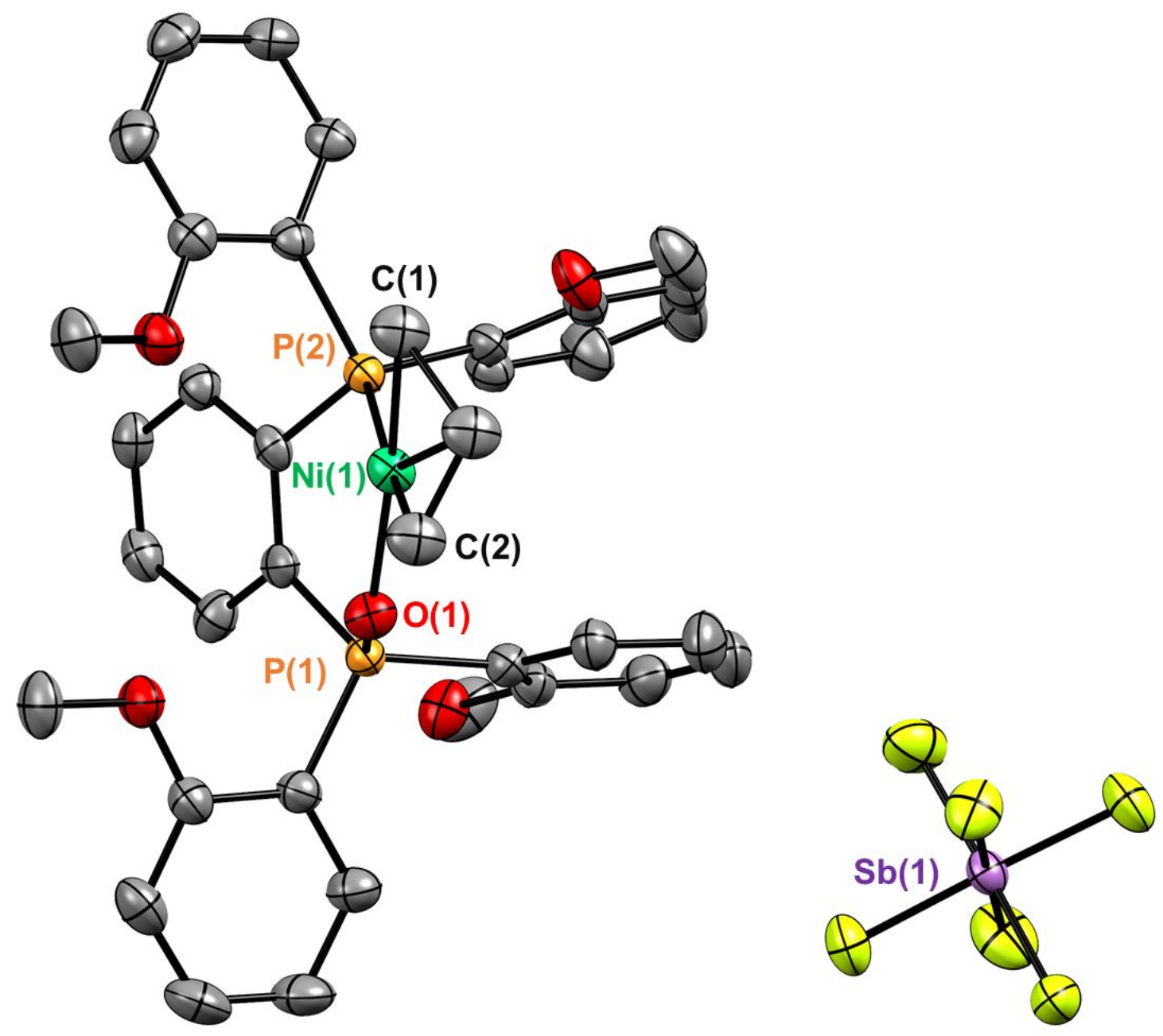

Figure S59. X-ray crystallographic characterization of Ni2. Hydrogen atoms were omitted for clarity. Atom colors: green $=$ nickel, orange $=$ phosphine, $r e d=$ oxygen, Dark gray $=$ carbon, yellow $=$ fluorine, magenta $=$ antimony. 


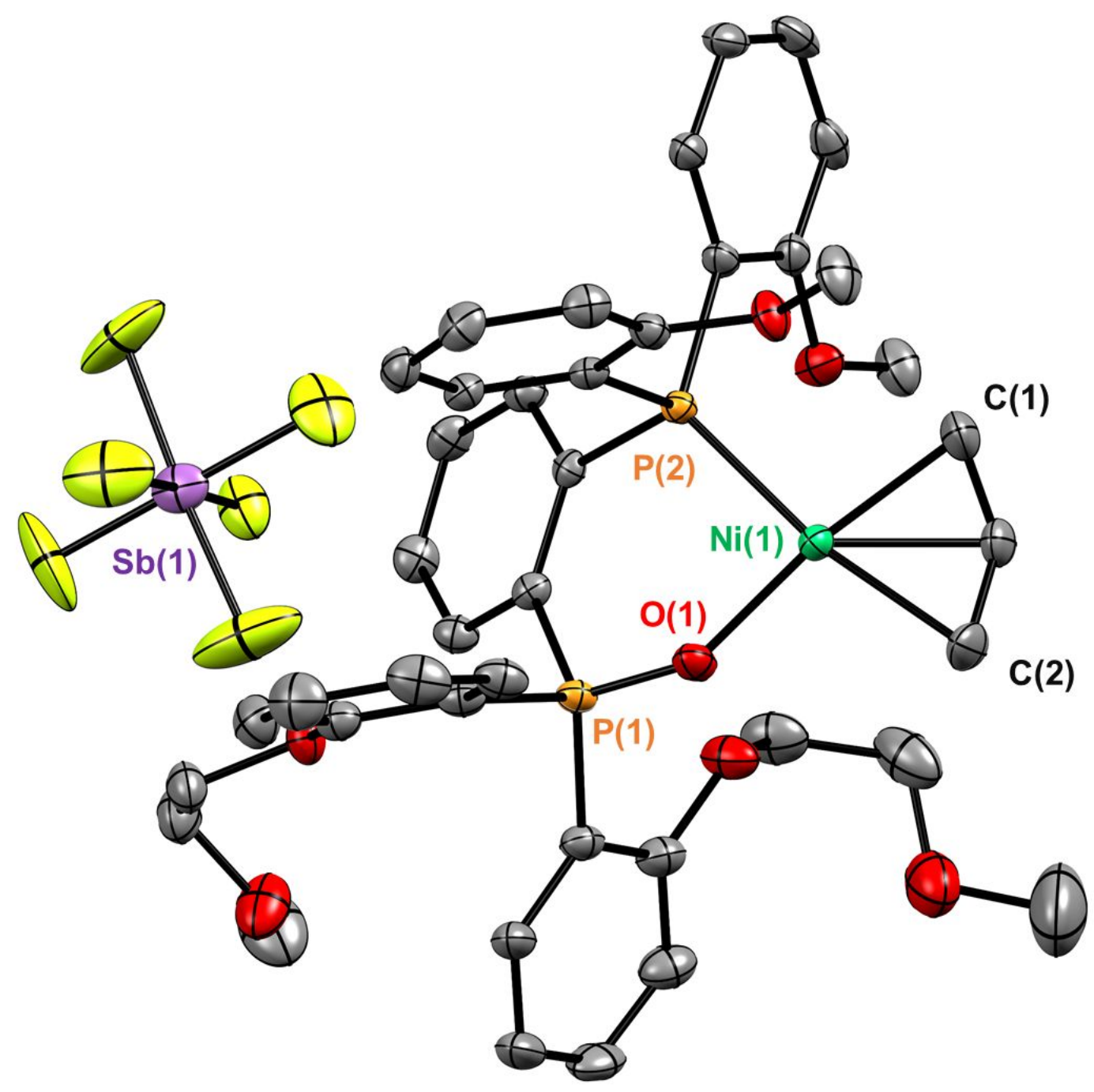

Figure S60. X-ray crystallographic of Ni3. Hydrogen atoms were omitted for clarity. Atom colors: green $=$ nickel, orange $=$ phosphine, red $=$ oxygen, Dark gray $=$ carbon, yellow $=$ fluorine, magenta $=$ antimony. 
Table S11. Crystal Data and Structure Refinement

\begin{tabular}{|c|c|c|}
\hline & $\mathrm{Ni2}$ & Ni3 \\
\hline Empirical Formula & $\mathrm{C}_{37} \mathrm{H}_{37} \mathrm{NiO}_{5} \mathrm{P}_{2} \mathrm{SbF}_{6}$ & $\mathrm{C}_{41} \mathrm{H}_{45} \mathrm{NiO}_{7} \mathrm{P}_{2} \mathrm{SbF}_{6}$ \\
\hline Formula Weight & 918.06 & 1006.17 \\
\hline Temperature $\left({ }^{\circ} \mathrm{C}\right)$ & -150 & -150 \\
\hline Wavelength $(\AA)$ & 1.54178 & 0.71073 \\
\hline Crystal System & Triclinic & Triclinic \\
\hline Space Group & $\mathrm{P}-1$ & $P-1$ \\
\hline \multicolumn{3}{|l|}{ Unit Cell Dimensions } \\
\hline$a(\AA)$ & $10.8910(9)$ & $10.7910(7)$ \\
\hline$b(\AA)$ & $13.1439(13)$ & $12.1150(8)$ \\
\hline$c(\AA)$ & $14.0026(12)$ & $17.6762(12)$ \\
\hline$\alpha\left(^{\circ}\right)$ & $105.920(4)$ & $107.153(1)$ \\
\hline$\beta\left(^{\circ}\right)$ & $95.953(5)$ & $99.188(1)$ \\
\hline$\gamma\left({ }^{\circ}\right)$ & $99.421(6)$ & $94.740(1)$ \\
\hline Volume $\left(\AA^{3}\right)$ & $1878.1(3)$ & $2159.0(2)$ \\
\hline Z, Calculated Density $\left(\mathrm{Mg} / \mathrm{m}^{3}\right)$ & $2,1.623$ & $2,1.548$ \\
\hline Absorption Coefficient $\left(\mathrm{mm}^{-1}\right)$ & 7.761 & 1.209 \\
\hline $\mathbf{F}(000)$ & 924 & 1020 \\
\hline Theta Range for Data Collection $\left(^{\circ}\right)$ & 3.323 to 65.915 & 1.229 to 26.370 \\
\hline Limiting Indices & $\begin{array}{l}-12 \leq \mathrm{h} \leq 12 \\
-15 \leq \mathrm{k} \leq 15 \\
-16 \leq 1 \leq 16\end{array}$ & $\begin{array}{l}-13 \leq \mathrm{h} \leq 10 \\
-13 \leq \mathrm{k} \leq 15 \\
-21 \leq 1 \leq 22\end{array}$ \\
\hline Reflections Collected/ Unique & $28608 / 6329$ & $12399 / 8628$ \\
\hline Completeness to theta $(\%)$ & 96.8 & 98.5 \\
\hline Data/ Restraints/ Parameters & $6329 / 0 / 471$ & $8628 / 93 / 595$ \\
\hline Goodness of Fit on $F^{2}$ & 1.059 & 1.080 \\
\hline $\begin{array}{l}\text { Final R Indices } \\
{[\mathrm{I}>2 \sigma(\mathrm{I})]}\end{array}$ & $\begin{array}{c}\mathrm{R} 1=0.0318 \\
\mathrm{wR} 2=0.0864\end{array}$ & $\begin{array}{c}\mathrm{R} 1=0.0273 \\
\mathrm{wR} 2=0.0737\end{array}$ \\
\hline R Indices (All Data)* & $\begin{array}{c}\mathrm{R} 1=0.0347 \\
\mathrm{wR} 2=0.0885\end{array}$ & $\begin{array}{c}\mathrm{R} 1=0.0314 \\
\mathrm{wR} 2=0.0809\end{array}$ \\
\hline Largest Diff. Peak and Hole $\left(\mathrm{e} \AA^{-3}\right)$ & 0.750 and -0.704 & 0.648 and -0.653 \\
\hline
\end{tabular}

$* \mathrm{R}_{1}=\Sigma \| F_{o}|-| F_{o}|| / \Sigma\left|F_{o}\right| ; \mathrm{wR}_{2}=\left[\Sigma\left[w\left(F_{o}{ }^{2}-F_{c}{ }^{2}\right)^{2}\right] / \Sigma\left[w\left(F_{o}{ }^{2}\right)_{2}\right]\right]^{1 / 2} ; \mathrm{GOF}=\left[\Sigma\left[w\left(F_{o}{ }^{2}-F_{c}{ }^{2}\right)_{2}\right] /(n-p)\right]^{1 / 2}$, where $n$ is the number of reflections and $p$ is the total number of parameters refine. 


\section{References}

(1) Contrella, N. D.; Sampson, J. R.; Jordan, R. F. Copolymerization of Ethylene and Methyl Acrylate by Cationic Palladium Catalysts That Contain Phosphine-Diethyl Phosphonate Ancillary Ligands. Organometallics 2014, 33, 3546-3555.

(2) Drent, E.; van Dijk, R.; van Ginkel, R.; van Oort, B.; Pugh, R. I. Palladium Catalysed Copolymerisation of Ethene with Alkylacrylates: Polar Comonomer Built into the Linear Polymer Chain. Chem. Commun. 2002, 744-745.

(3) Andrei, S. A.; Meijer, F. A.; Neves, J. F.; Brunsveld, L.; Landrieu, I.; Ottmann, C.; Milroy, L.-G. Inhibition of 14-3-3/Tau by Hybrid Small-Molecule Peptides Operating via Two Different Binding Modes. ACS Chem. Neurosci. 2018, 9, 2639-2654.

(4) Cai, Z.; Do, L. H. Thermally Robust Heterobimetallic Palladium-Alkali Catalysts for Ethylene and Alkyl Acrylate Copolymerization. Organometallics 2018, 37, 3874-3882.

(5) Xiao, D.; Cai, Z.; Do, L. H. Accelerating Ethylene Polymerization Using Secondary Metal Ions in Tetrahydrofuran. Dalton Trans. 2019, 48, 17887-17897.

(6) Busacca, C. A.; Lorenz, J. C.; Grinberg, N.; Haddad, N.; Hrapchak, M.; Latli, B.; Lee, H.; Sabila, P.; Saha, A.; Sarvestani, M.; Shen, S.; Varsolona, R.; Wei, X.; Senanayake, C. H. A Superior Method for the Reduction of Secondary Phosphine Oxides. Org. Lett. 2005, 7, 42774280.

(7) Yang, G.-H.; Zheng, H.; Li, X.; Cheng, J.-P. Asymmetric Synthesis of Axially Chiral Phosphamides via Atroposelective N-Allylic Alkylation. ACS Catal. 2020, 10, 2324-2333.

(8) Brynn Hibbert, D.; Thordarson, P. The Death of the Job Plot, Transparency, Open Science and Online Tools, Uncertainty Estimation Methods and Other Developments in Supramolecular Chemistry Data Analysis. Chem. Commun. 2016, 52, 12792-12805.

(9) Thordarson, P. Determining Association Constants from Titration Experiments in Supramolecular Chemistry. Chem. Soc. Rev. 2011, 40, 1305-1323.

(10) http://supramolecular.org (accessed July 2021)

(11) Cui, L.; Jian, Z. A N-Bridged Strategy Enables Hemilabile Phosphine-Carbonyl Palladium and Nickel Catalysts to Mediate Ethylene Polymerization and Copolymerization with Polar Vinyl Monomers. Polym. Chem. 2020, 11, 6187-6193.

(12) Zhang, Y.; Mu, H.; Pan, L.; Wang, X.; Li, Y. Robust Bulky [P,O] Neutral Nickel Catalysts for Copolymerization of Ethylene with Polar Vinyl Monomers. ACS Catal. 2018, 8, 5963-5976.

(13) Wang, X.-1.; Zhang, Y.-p.; Wang, F.; Pan, L.; Wang, B.; Li, Y.-s. Robust and Reactive Neutral Nickel Catalysts for Ethylene Polymerization and Copolymerization with a Challenging 1,1Disubstituted Difunctional Polar Monomer. ACS Catal. 2021, 2902-2911.

(14) Saki, Z.; D’Auria, I.; Dall'Anese, A.; Milani, B.; Pellecchia, C. Copolymerization of Ethylene and Methyl Acrylate by Pyridylimino Ni(II) Catalysts Affording Hyperbranched Poly(ethylene-co-methyl acrylate)s with Tunable Structures of the Ester Groups. Macromolecules 2020, 53, 9294-9305.

(15) Liang, T.; Goudari, S. B.; Chen, C. A Simple and Versatile Nickel Platform for the Generation of Branched High Molecular Weight Polyolefins. Nat. Commun. 2020, 11, 372.

(16) Zou, C.; Liao, D.; Pang, W.; Chen, M.; Tan, C. Versatile PNPO Ligands for Palladium and Nickel Catalyzed Ethylene Polymerization and Copolymerization with Polar Monomers. $J$. Catal. 2021, 393, 281-289.

(17) Chen, M.; Chen, C. A Versatile Ligand Platform for Palladium- and Nickel-Catalyzed Ethylene Copolymerization with Polar Monomers. Angew. Chem., Int. Ed. Engl. 2018, 57, 3094-3098. 
(18) Xu, M.; Yu, F.; Li, P.; Xu, G.; Zhang, S.; Wang, F. Enhancing Chain Initiation Efficiency in the Cationic Allyl-Nickel Catalyzed (Co)Polymerization of Ethylene and Methyl Acrylate. Inorg. Chem. 2020, 59, 4475-4482.

(19) Li, M.; Wang, X.; Luo, Y.; Chen, C. A Second-Coordination-Sphere Strategy to Modulate Nickel- and Palladium-Catalyzed Olefin Polymerization and Copolymerization. Angew. Chem., Int. Ed. Engl. 2017, 56, 11604-11609.

(20) Xin, B. S.; Sato, N.; Tanna, A.; Oishi, Y.; Konishi, Y.; Shimizu, F. Nickel Catalyzed Copolymerization of Ethylene and Alkyl Acrylates. J. Am. Chem. Soc. 2017, 139, 3611-3614. 